University of Louisville ThinkIR: The University of Louisville's Institutional Repository

Electronic Theses and Dissertations

$12-2013$

\title{
Linking corporate strategy to operations : a critical review of Prof. Kaplan's theories and the development of a best-practice approach.
}

Alexander Bogner

University of Louisville

Follow this and additional works at: https://ir.library.louisville.edu/etd

Part of the Industrial Engineering Commons

\section{Recommended Citation}

Bogner, Alexander, "Linking corporate strategy to operations : a critical review of Prof. Kaplan's theories and the development of a best-practice approach." (2013). Electronic Theses and Dissertations. Paper 2283.

https://doi.org/10.18297/etd/2283

This Doctoral Dissertation is brought to you for free and open access by ThinkIR: The University of Louisville's Institutional Repository. It has been accepted for inclusion in Electronic Theses and Dissertations by an authorized administrator of ThinkIR: The University of Louisville's Institutional Repository. This title appears here courtesy of the author, who has retained all other copyrights. For more information, please contact thinkir@louisville.edu. 


\title{
LINKING CORPORATE STRATEGY TO OPERATIONS
}

\author{
A CRITICAL REVIEW OF PROF. KAPLAN'S THEORIES \\ AND THE DEVELOPMENT OF A BEST-PRACTICE APPROACH \\ By \\ Alexander Bogner
}

Dissertation

Submitted to the Faculty of the

J. B. School of Engineering of the University of Louisville in Partial Fulfillment of the Requirements for the

Doctor of Philosophy

Department of Industrial Engineering

University of Louisville

Louisville, Kentucky, USA

December 2013 
(C) Copyright 2013 by Alexander Bogner

All rights Reserved 



\title{
LINKING CORPORATE STRATEGY TO OPERATIONS
}

\author{
A CRITICAL REVIEW OF PROF. KAPLAN'S THEORIES \\ AND THE DEVELOPMENT OF A BEST-PRACTICE APPROACH
}

\author{
by \\ Alexander Bogner \\ Diplom Kaufmann, HFH Hamburg, 2005 \\ Master of Science Industrial Engineering, University of Louisville, 2010
}

A Dissertation Approved on

December 02, 2013

by the following Thesis or Dissertation Committee:

Dr. William E. Biles, Dissertation Director

Dr. Gerald W. Evans

Dr. Lihui Bai

Dr. Thomas Riedel 


\section{DEDICATION}

This dissertation is dedicated to my wife Mrs. Anja Bogner. 


\section{ACKNOWLEDGEMENTS}

I would like to thank my major professor, Dr. William Biles, for his guidance

and patience. I would also like to thank the other committee members for their comments and assistance over the past years.

I would also like to express my thanks to my wife, Anja, for her understanding and patience during those times when there was no light at the end of anything. She encouraged me and made me stick with it.

Also, many thanks to my company partner Tom Meixner and to Dirk Mailänder for the support and the helping hand over the last three years. 


\section{ABSTRACT \\ LINKING CORPORATE STRATEGY TO OPERATIONS \\ Alexander Bogner \\ December 02, 2013}

The rising speed of change in global frameworks drives international companies into a non-stop changing organization with the need of generating optimal revenues under changing conditions. Regarding to the need to be a flexible and competitive organization the value of a vision and a perfectly streamed strategy to this vision becomes a main success factor for global business.

The trend for the need of development of a clear and constant strategy is equally rising with the trend of globalization and intercontinental business companies and therefor the business of strategy consulting rises constantly from the late 1990 .

Most of the strategy consulting companies concentrate their business on consulting companies with strategy and vision ideas and concepts with the focus on the innovation of new products and services to conquer new markets or to optimize their organizations and processes. The main focus is to provide a strategy concept with respect to cross knowledge of other industries and a set of standardized consulting methods out of their own experience or provided by research departments connected to business universities and institutes.

The topic of how this strategy concept is linked to the operation business of the company is nearly never presented by these strategy consulting companies. So the result 
of the consulting projects is a well-defined and workedout strategy concept, proven by the leader board but without any concept, set of methods or any approach how to realize the ideas of the concept in the "real world".

Prof. Kaplan realized this lack in the business world and provided several research papers and extended books to support companies with solutions solving this problem.

Especially his latest work "The execution premium" concentrates his research on the topic how to link worked-out strategies to operations for competitive advantages.

The first aim of the dissertation is to review and analyze the theories from Prof. Kaplan, focusing on "the execution premium".

As the second aim the dissertation will document the execution of his provided concepts and methods in a "real-life" experiment followed by a gap analysis of the experiment with respect to Kaplan's theories. Finally the heart of the dissertation will be the development of a best-practice approach to fill up selected gaps and provide a general and integrated approach including a seamless-linked method tool kit for the realization of strategies in companies focusing on the field of executing the strategic initiatives 
TABLE OF CONTENTS

1.1 Challenge TO LiNK STRATEgY TO OPERATIONS 1

$\begin{array}{llr}1.2 & \text { Problem Statement } & 2\end{array}$

$\begin{array}{llr}1.3 & \text { RESEARCH CONTRIBUTION } & 3\end{array}$

$\begin{array}{llr}1.4 & \text { SCOPE OF THE DISSERTATION } & 3\end{array}$

$\underline{2}$ LITERATURE REVIEW - KAPLAN'S THEORIES

$\begin{array}{lll}2.1 & \text { THE EXECUTION PREMIUM } & 4\end{array}$

2.1.1 STEP 1: DEVELOPMENT OF THE STRATEGY 6

$\begin{array}{lll}\text { 2.1.2 SteP 2: Plan the STRATEGy } & 13\end{array}$

$\begin{array}{lll}\text { 2.1.3 StEP 3: Align the ORGANIZATION } & 23\end{array}$ 
2.1.4 SteP 4: Plan OPERATIONS 29

2.1.5 STEP 5: MONITOR AND LEARN 46

2.1.6 STEP 6: TEST AND ADAPT $\quad 50$

2.1.7 THE OFFICE OF STRATEGY MANAGEMENT

2.2 BALANCED SCORE CARD: Translating STRATEGY INTO ACTION

2.2.1 Perspective One: "Financial Perspective” 60

2.2.2 Perspective Two: "Customer Perspective” 61

2.2.3 Perspective Three: "Internal Business-Process PersPective” 62

2.2.4 PersPeCtIVE Four: "LEARNING AND GROWTH PERSPECTIVE” 62

2.2.5 "FeEdBack AND the Strategic LEARning PRocess" 63

$\begin{array}{lll}2.3 & \text { THE STRATEGY-FOCUSED ORGANIZATION } & 63\end{array}$

2.3.1 Principle 1: “Translate the Strategy to Operational Terms” 64

2.3.2 Principle 2: “Align the Organization to the Strategy” 65

2.3.3 PRINCIPLE 3: “MAKe StRATEGy EVERYONE’s EVERyday JoB”

2.3.4 Principle 4: "Make Strategy a Continual Process" 66

2.3.5 PRINCIPLe 5: "MobILIZE Change through EXECUtIVE LEADERShIP” 66

$\underline{3}$ EXPERIMENT $\quad 68$

$\begin{array}{llr}3.1 & \text { ENVIRONMENT FOR THE EXPERIMENT } & 68\end{array}$

3.2 STEP 1 AND 2: DEVELOP AND PLAN THE STRATEGY

3.3 STEP 3: ALIGN THE ORGANIZATION

3.4 Step 4-6: Plan Operations, Execution, Monitor and Learn, Test and

$\begin{array}{lr}\text { ADAPT } & \mathbf{7 0}\end{array}$

$\begin{array}{lll}3.5 & \text { CONCLUSION } & 71\end{array}$

4 GAP-ANALYSIS: KAPLAN'S THEORY AND PRAXIS EXPERIMENT 72 
$\begin{array}{lll}\text { 4.2 STEP 3 - ALIGN THE ORGANIZATION } & 75\end{array}$

4.3 Step 4-6 - Plan Operations, Execution, Monitor and Learn, Test AND $\begin{array}{ll}\text { ADAPT } & \mathbf{7 6}\end{array}$

$\begin{array}{lll}4.4 & \text { Conclusion } & 77\end{array}$

$\underline{5}$ APPROACH FOR BEST-PRACTICE SOLUTION: ISOL-M

$\begin{array}{lll}5.1 & \text { GENERAL APPROACH - PTO }\end{array}$

$\begin{array}{llr}5.2 & \text { ISOL-M - THE MODEL } & 80\end{array}$

5.3 ORGANIZATIONAL REQUIREMENTS FOR ISOL-M 82

5.3.1 Strategic Management Organization (SMOrG) 83

5.3.2 InITIATIVE AND PROGRAM ORgANIZATION (IPORG) 83

5.3.3 Project OrganiZATION (PORG) 84

5.3.4 Strategy Management Board Organization (SMBORG) 84

5.3.5 PROCESS AND RACI $\quad 85$

$\begin{array}{lll}5.4 & \text { Phase 1: Strategy Development } & 86\end{array}$

$\begin{array}{lll}\text { 5.4.1 COMMUNICATION CONCEPT } & 87\end{array}$

$\begin{array}{lll}\text { 5.4.2 SELECTION OF STRATEGY ANALYSIS METHODS } & 87\end{array}$

$\begin{array}{llr}\text { 5.4.3 STRATEGIC FORMULATION } & 90\end{array}$

$\begin{array}{lll}\text { 5.4.4 ORGANIZATIONAL RESPONSIBILITY } & 91\end{array}$

5.5 Phase 2: Strategy Planning 92

5.5.1 THE WAY TO STRATEGIC INITIATIVES AND PROGRAMS 92

$\begin{array}{ll}\text { 5.5.2 INTEGRATED STRATEX TOOL } & 95\end{array}$

$\begin{array}{lll}\text { 5.5.3 ORGANIZATIONAL RESPONSIBILITY } & 97\end{array}$

$\begin{array}{lll}\text { 5.6 Phase 3: Capacity Setur } & 97\end{array}$

$\begin{array}{lll}5.7 & \text { Phase 4: EXecution } & 100\end{array}$ 
5.7.1 SteP 1: Project IdEa Evaluation

$\begin{array}{lll}\text { 5.7.2 SteP 2: Project PRESENTATION AND DeCision } & 105\end{array}$

$\begin{array}{lll}\text { 5.7.3 StEP 3: Project REQUIREMENTS } & 116\end{array}$

$\begin{array}{lll}\text { 5.7.4 SteP 4: Project APPROVAL } & 117\end{array}$

$\begin{array}{lll}\text { 5.7.5 SteP 5: Project EXECUTION } & 117\end{array}$

6 CONCLUSION 135

\begin{tabular}{lr} 
REFERENCES & 141 \\
\hline
\end{tabular}

$\begin{array}{lr}\text { APPENDIX } & 144\end{array}$

\begin{tabular}{lr} 
CURRICULUM VITA & 146 \\
\hline
\end{tabular} 


\section{LIST OF TABLES}

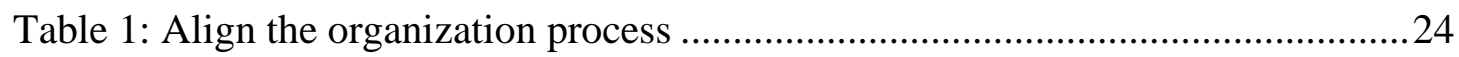

Table 2: Main process in planning operations …...................................................... 30

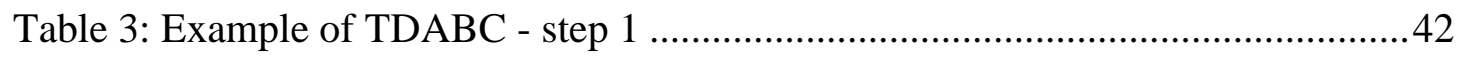

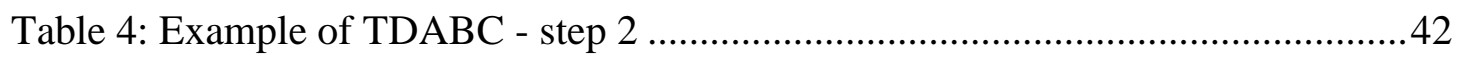

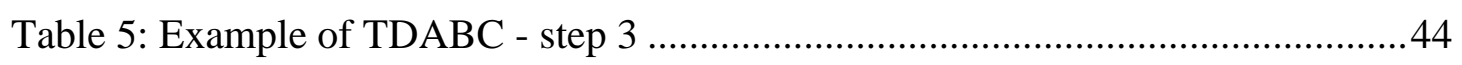

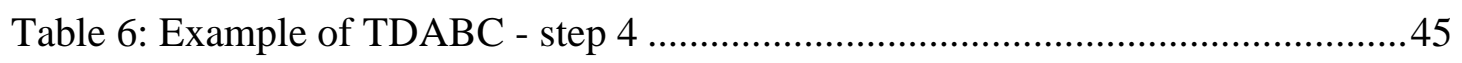

Table 7: Overview of Monitor and Learn Meetings ................................................ 47

Table 8: Overview of Reviews, Testing and Adaption............................................5

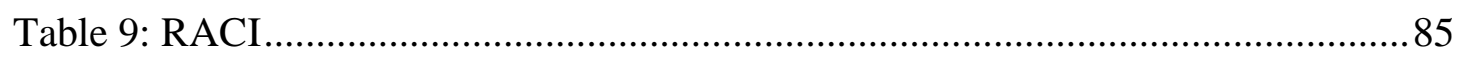

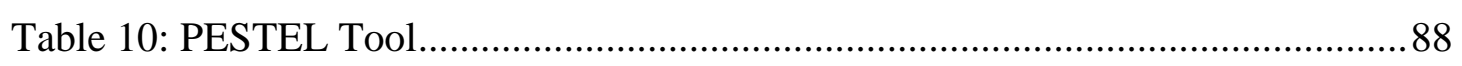

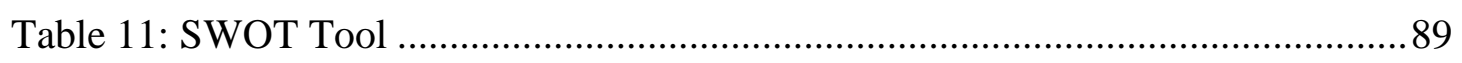

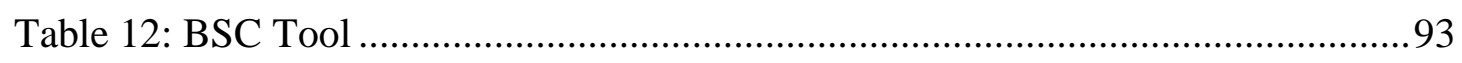

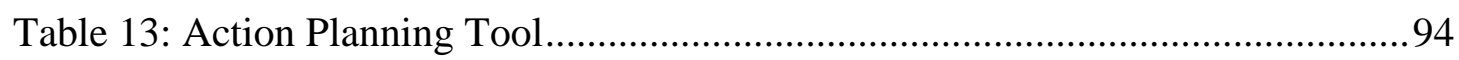

Table 14: Initiative and Program Planning Tool..................................................... 95

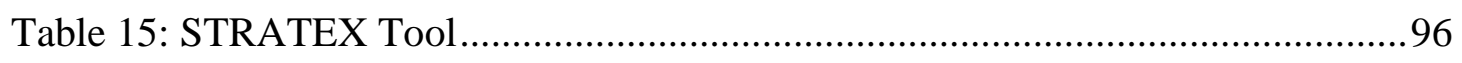

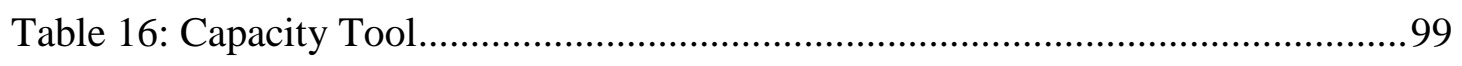

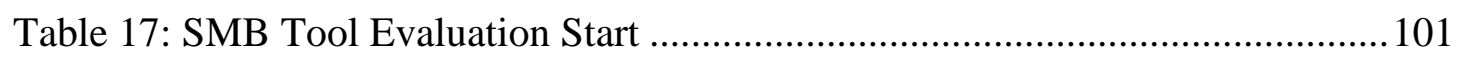

Table 18: SMB Tool Project Decision - Project Benefit Calculation ......................... 106

Table 19: SMB Tool Project Decision - Project Contribution Calculation ................ 108

Table 20: SMB Tool Project Decision - Project Ranking - Calculation..................... 109

Table 21: SMB Tool Project Decision - Project Time Calculation ........................... 110 
Table 22: SMB Tool Project Decision - Project Resource Utilization Calculation... 111

Table 23: SMB Tool Project Decision - Project Activity Index per Month ...............112

Table 24: SMB Tool Project Decision - Person Activity Index .............................. 113

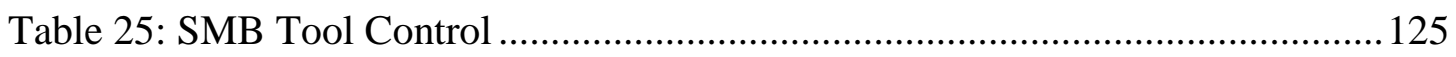

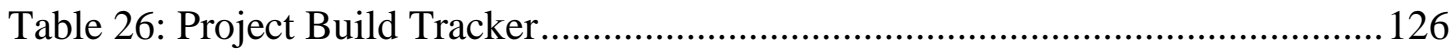

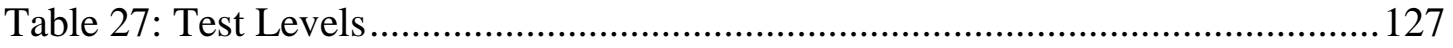




\section{LIST OF FIGURES}

Figure 1: Wall Street Journal - survey Top Five Management Concerns ..................... 1

Figure 2: The management system from Kaplan ................................................

Figure 3: enhanced vision with four prospective framework of strategy maps .............8

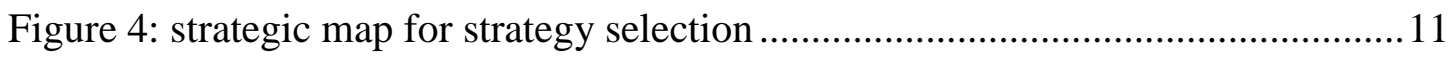

Figure 5: Strategic Formulation Guidelines......................................................... 12

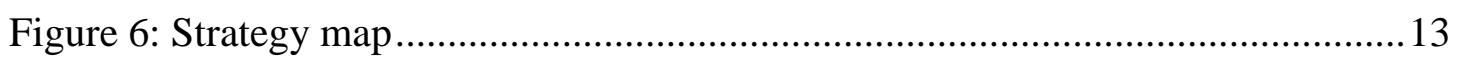

Figure 7: BSC method for definition of measures and targets.................................. 15

Figure 8: Example at Customer Bank: Value GAP and target setting....................... 16

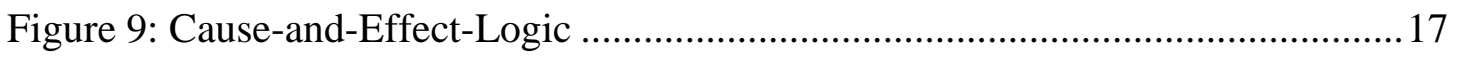

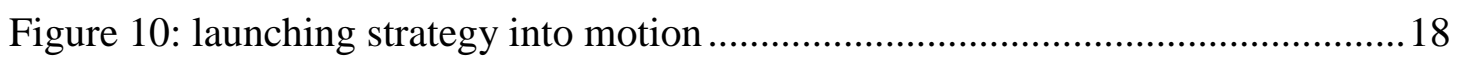

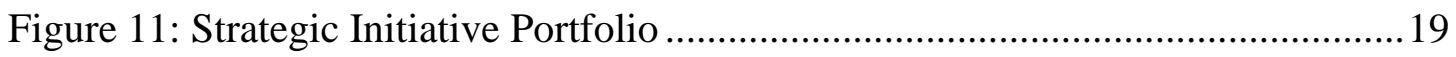

Figure 12: General View of Budgeting with STRATEX........................................21

Figure 13: Detailed View of Budgeting with STRATEX ........................................22

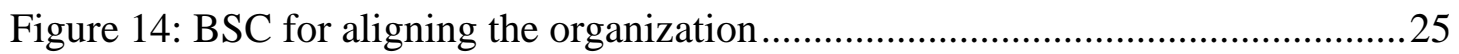

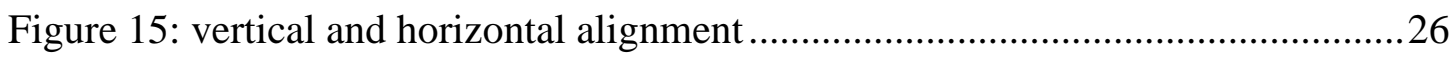

Figure 16: Link between process improvement and BSC strategic priorities ..............31

Figure 17: linking process management to BSC strategic processes...........................33

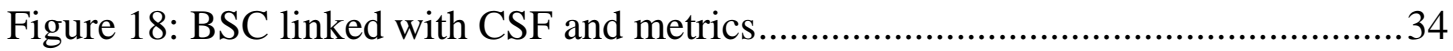

Figure 19: Link between Strategy Map, cause-and-effect model and dashboards .......35

Figure 20: Integrated suite for targeted management control processes......................36

Figure 21: structure for a strategy review meeting ...............................................49 
Figure 22: overview of tasks in the management system .55

Figure 23: Roles of the OSM .56

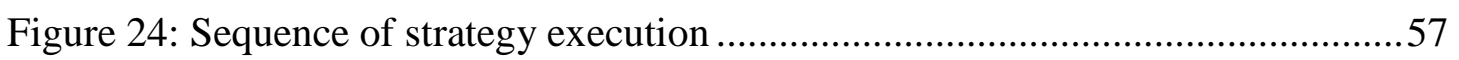

Figure 25: Five principles of strategy-focused organization ....................................6 64

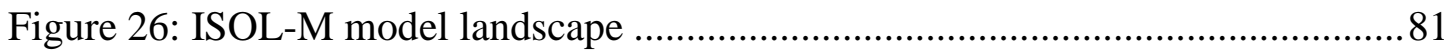

Figure 27: Communication Concept Tool …...................................................... 87

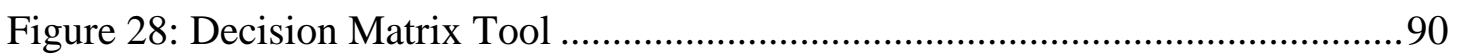

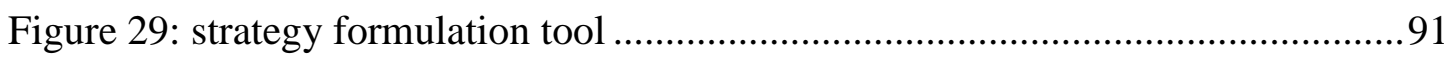

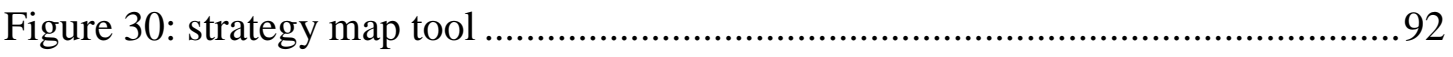

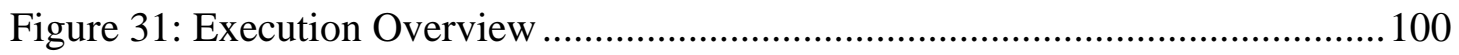

Figure 32: SMB Tool - project idea evaluation .................................................... 102

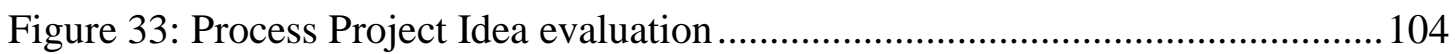

Figure 34: SMB Tool Project Decision - Project Benefit Graph .............................. 107

Figure 35: SMB Tool Project Decision - Project Ranking - Graph ......................... 109

Figure 36: SMB Tool Project Decision - Project Time Graph .................................. 110

Figure 37: SMB Tool Project Decision - Project Resource Utilization Calculation .111

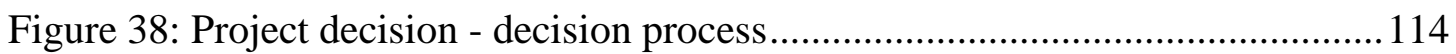

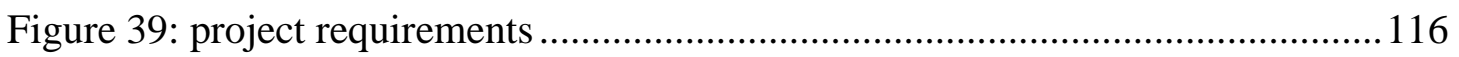

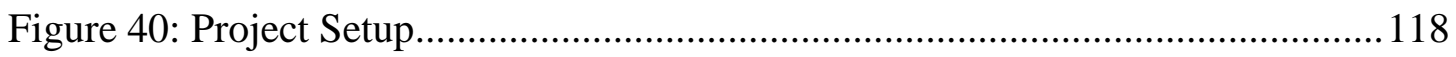

Figure 41: Demand evaluation and approval ..................................................... 120

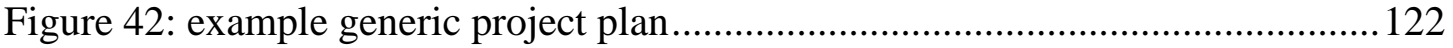

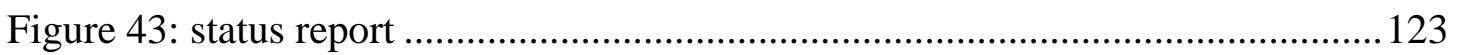

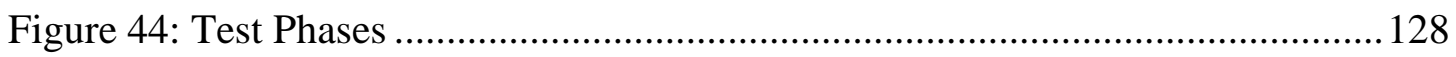

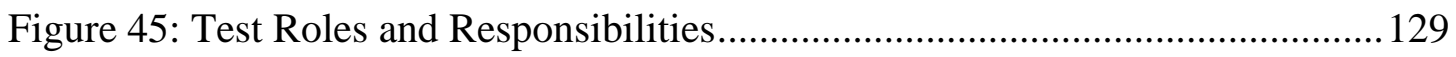

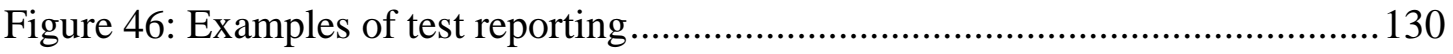




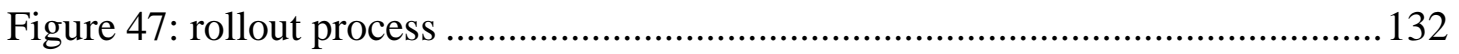

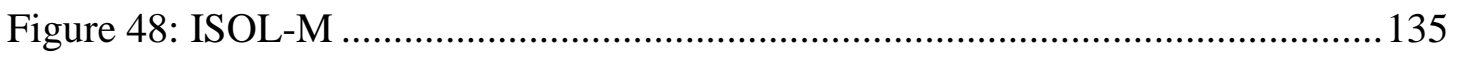




\section{INTRODUCTION}

\subsection{Challenge to link strategy to operations}

Developing sustainable and flexible strategies is a key factor for the company success in global markets. For that reason many of the top companies set up a strategy team with their own top management and external consulting companies like Boston Consulting, McKinsey or Roland Berger strategy consultants.

A survey from the Wall Street Journal (Tuna, 2008) shows that over 50\% of the CEO's have the main concern that these strategies are not or badly realized on an operational organization level.

\section{THE WALL STREET JOURNAL}

CAREERS I NOVEMBER 20, 2008, 12:21 A.M. ET

Executives Shift to Survival Work-Force Issues Move to Back Bumer as Financial BY OARI TUNA

Business executives are shuffling their prioritie and risk-management supplant work-force issue

The Conference Board last month again surveye and company presidents who were asked in July concerns. The differing results reflect the impac deepened in September, and the slowing global $e$

Among the 190 executives who responded to bo business strategy remained the top priority. But respondents, up from $25 \%$ in late summer -- said about "speed, flexibility [and] adaptability to ch: performance and financial risk were the fourthconcerns. Neither were among executives' top-1

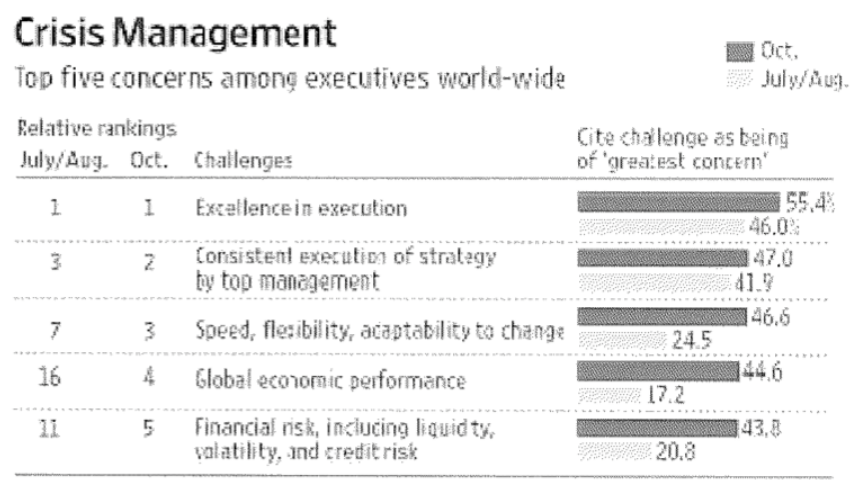

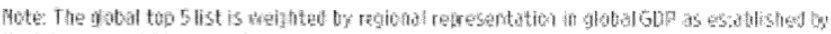
Tie Ifternational blon:tary Fund Sourter This Conference Board

Figure 1: Wall Street Journal - survey Top Five Management Concerns

Prof. Kaplan and Dr. Norton from Harvard University provide research papers and books about the problems between corporate strategy planning and the strategy realization in the company. 
Especially the book: "the execution premium: linking strategy to operations for competitive advantage" provides a 6-step method solving the problems and shows that the first approach from Prof. Kaplan only implementing a balanced-score-card standalone without linking this method to other methods of operations does not solve the problem.

\subsection{Problem Statement}

"Strategy without tactics is the slowest route to victory. Tactics without strategy is the noise before defeat." (Anonymous, $544 \mathrm{BC}$ )

The management of strategy and the management of operational business differ widely, but both are vital and need to be linked and integrated into a complete set of management activities. (Porter, 1996)

The main problems in this area can be identified and stated into three main topics:

1. Strategy plan is made by external consulting companies without internal view and problems of the company, only and not even that in every case, considering the top management view

2. Management Boards have not integrated the middle management layer of an organization, which should realize the strategy

3. A bunch of strategy-realization methods are stand-alone implemented in the organization - but without any inter-method-logic and interfaces

Even in the solutions provided by Prof. Kaplan the interaction und interfaces between these methods are barely elaborated and full of essential gaps for a practical application. 
This circumstances show the need of a critical review of Kaplan's theories and the development of a generic and integrated-strategy-to-operations-linking-model (ISOL-M) with the focus of seamless integration of existing strategy and operation methods.

\subsection{Research Contribution}

The dissertation is supposed to represent a detailed view on the research results of Prof. Kaplan's work with the focus on his latest work "the execution premium" and will provide a best-practice approach for an ISOL-M.

\subsection{Scope of the dissertation}

The dissertation is structured into four main parts.

Part one is an extended literature review of the main research papers and books of Prof. Kaplan with the focus on his latest work "the execution premium" but also considering his two other milestones in business literature "Balanced Score Card" and "The strategy focused organization".

The second part will provide an experiment for realizing the concepts and methods of Kaplan's "execution premium" in an international company.

The third part contributes a gap-analysis with showing the main lacks and gaps in the theories of Kaplan.

The main and fourth part of the dissertation provides an approach for a bestpractice ISOL-M. 


\section{LITERATURE REVIEW - KAPLAN'S THEORIES}

\subsection{The Execution premium}

The management system: Linking strategy to operations

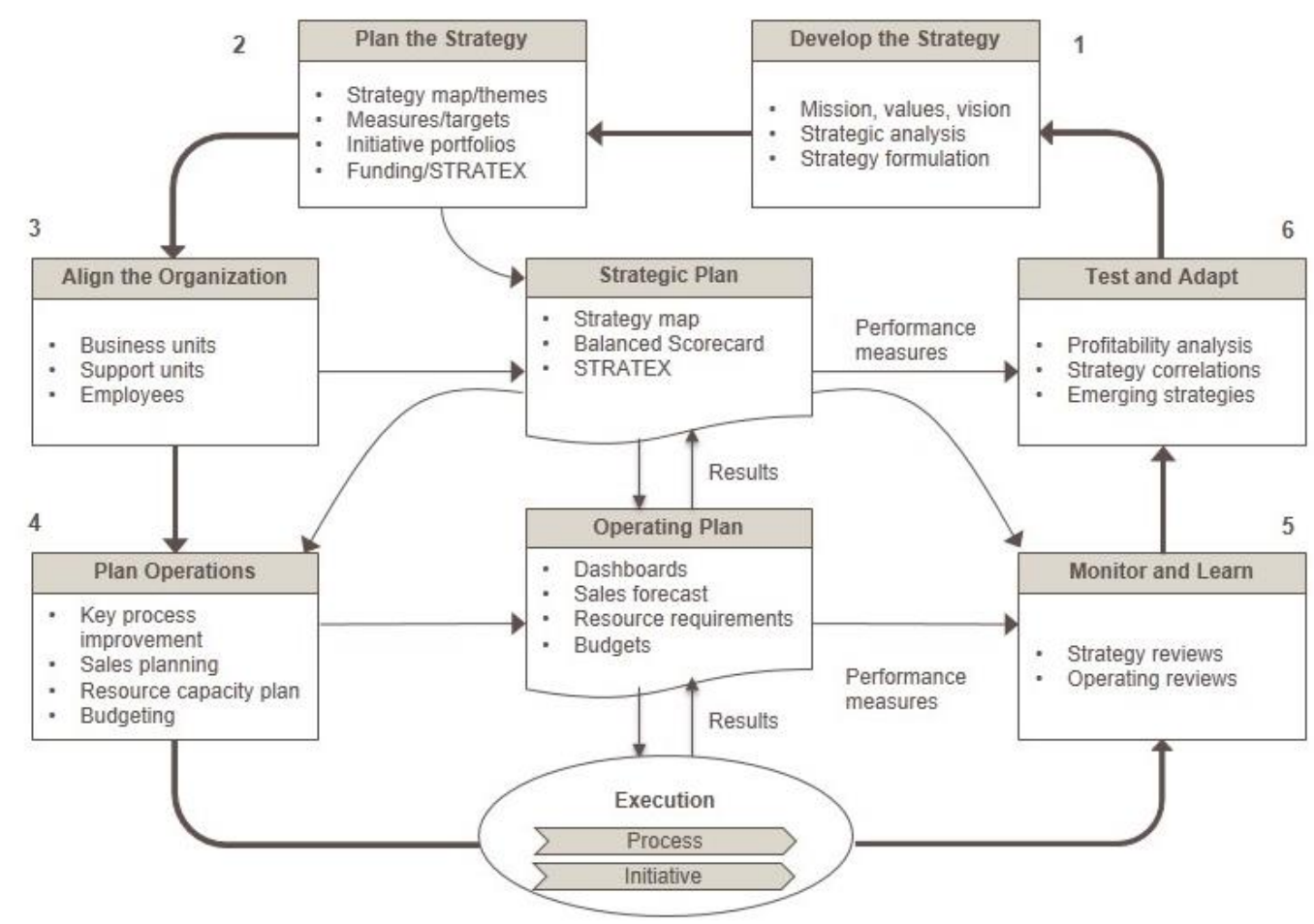

Figure 2: The management system from Kaplan 
Kaplan provides in his "The execution premium" (Kaplan \& Norton, The Execution Premium, 2008) a management system for integrating strategy planning and operational execution. This system has six major steps as shown in the above figure.

Stage 1 - Managers develop the strategy using the strategy tools

Stage 2 - The organization plans the strategy using tools such as strategy maps and Balanced Scorecards.

Stage 3 - align the organization with the strategy by cascading linked strategy maps and Balanced Scorecards to all organizational units.

Stage 4 - plan operations using tools such as quality and process management, reengineering, process dashboards, rolling forecasts, activity-based costing, resource capacity planning, and dynamic budgeting.

Stage 5 - As the strategy and operational plans are executed, the enterprise monitors and learns about problems, barriers, and challenges. This process integrates information about operations and strategy in a carefully designed structure of management review meetings.

Stage 6 - Managers use internal operational data and new external environmental and competitive data to test and adapt the strategy, launching another loop around the integrated strategy planning and operational execution system. (Kaplan \& Norton, The Execution Premium, 2008) 
"The execution premium" has the effort to provide a blueprint for management of strategy in the complete lifecycle of the strategy and the linking to operations. But the authors stated that there is one component they are not able to provide: a visionary and effective leadership.

Kaplan stated the role for leadership very highly at the beginning of his book. The only common element all these diverse successful strategy implements have in common is exceptional and visionary leadership. He declares that leadership is so important to the strategy management system in every single step of the system that he calls it necessary and sufficient. He continues that in every instance, the CEO of the organizational unit implementing the new strategy management system has to lead the process to develop the strategy and oversee its implementation. No organization reporting success with the strategy management system had an unengaged or passive leader. (Kaplan \& Norton, The Execution Premium, 2008)

\subsubsection{Step 1: Development of the strategy}

As shown in figure 2 strategy management is a closed-loop process, with each part of the system influencing every other part. (Kaplan \& Norton, The Execution Premium, 2008)

The first step of the system is the development of the strategy. This includes mainly the three following major processes

a) Definition of Mission, Values and vision

b) Strategic analysis

c) Strategic formulation 


\subsubsection{Definition of mission, values and vision}

Before formulating a strategy, managers need to agree on the company's purpose (mission), the internal compass that will guide its actions (values), and its aspiration for future (vision). (Kaplan \& Norton, The Execution Premium, 2008)

In this step, the mission in form of a mission statement (defining why the organization exists), the values in form of a values statement or core values and the vision in form of a vision statement (long-term goals of the organization) need to be formulated.

The outputs of this first process in developing the strategy are three main results: the value gap, the strategic change agenda and the enhanced vision.

\subsection{The value gap}

The value gap compares the actual formulation of values to the future values formulated in the value statement.

\subsection{The Strategic Change Agenda}

Kaplan provides the thesis that people in the organization may not understand why the vision statement needs a new strategy and why they need to change in order to achieve the target. Creating a sense of urgency and communicating the need for change are critical roles for leadership. (Kotter, 1996)

The Strategic Change Agenda compares the current status of several organizational structures, capabilities, and processes with what they need to become over the next three to five years and this tool provides the motivation for why 
transformational change is necessary. (Kaplan \& Norton, The Execution Premium, 2008)

\subsection{Defining the Enhanced Vision}

Kaplan states that strategy execution requires an architecture that integrates the strategies and operations of divers units scattered throughout an enterprise. The executive team can use a strategy map's four-prospective framework to define an enhanced vision, as shown in figure 3. The enhanced vision statement provides a comprehensive picture of the enabling factors to achieve the vision, including the customer value proposition, key processes, and the intangible assets of people and technology. (Kaplan \& Norton, The Execution Premium, 2008) It is the link to the second step of Kaplan model "Plan the strategy".

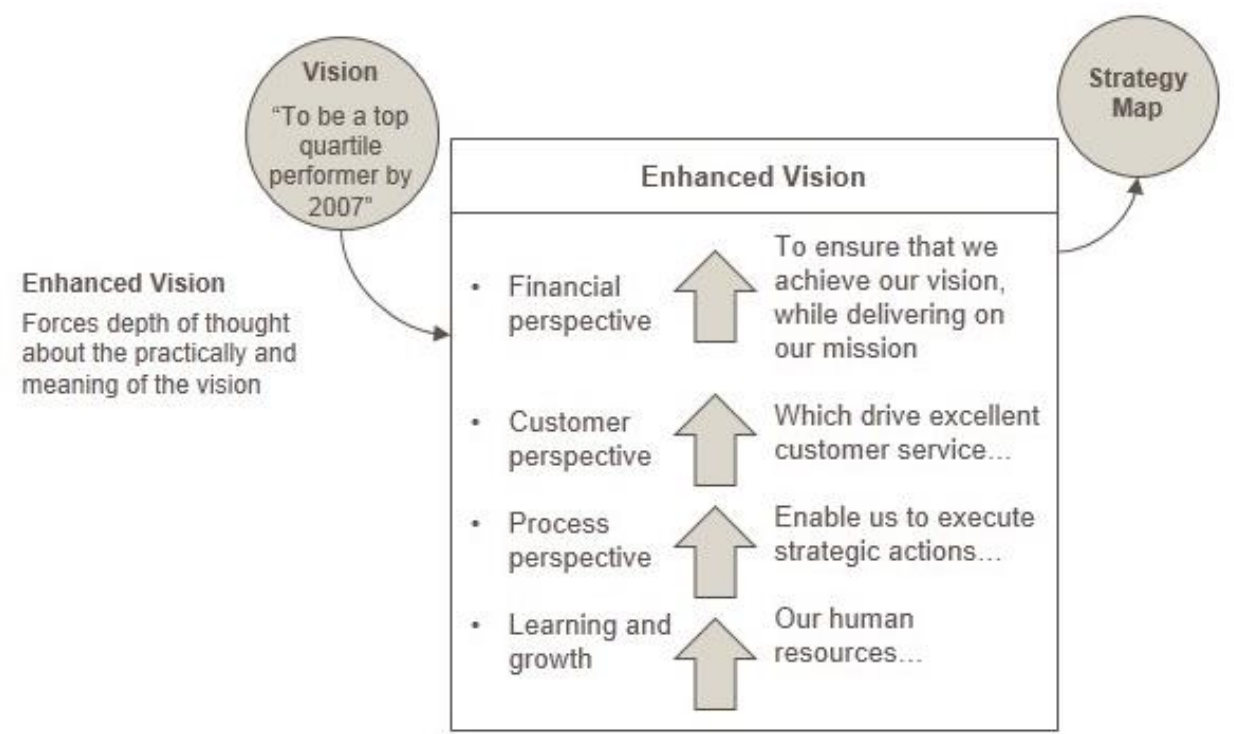

Figure 3: enhanced vision with four prospective framework of strategy maps 


\subsubsection{Strategic analysis}

Once process one is completed the company has a clear picture of what it needs to achieve. The next process is to perform an external and internal analysis that includes a comprehensive assessment of the company's capabilities and performance relative to its competitors and industry trends.

\subsection{External Analysis}

The executive team needs to understand the impact of macro- and industry-level trends on the company's strategy and operations.

The external analysis assesses the macroeconomic environment of economic growth, interest rates, currency movement, input factor price, regulations, and general expectations of the corporation's role in society. A method to fulfill these requirements to the external analysis is the PESTEL method. (Political, economic, social, technological, environmental, and legal). The external analysis includes an industrylevel examination of industry economics and competitor assessments, and finally, includes competitor assessments. (Kaplan \& Norton, The Execution Premium, 2008)

\subsection{Internal Analysis}

The internal analysis delivers results about an organization's own performance and capabilities. The value chain identifies the sequence of processes necessary to deliver a company's products and services to customers. The value chain model helps a firm identify those activities that it intends to perform differently or better than competitors to establish a sustainable competitive advantage. (Kaplan \& Norton, The Execution Premium, 2008) 
A further step is the estimation of an activity-based cost models for each process in the value chain.

\subsection{SWOT Analysis}

The next step is to conduct a SWOT analysis. The SWOT analysis identifies the company's existing strengths and weakness, its emerging opportunities, and the worrisome threats facing the organization. (Kaplan \& Norton, The Execution Premium, 2008)

A SWOT table summarizes these conditions to understand the key issues that the organization must address when formulating its strategy.

\subsubsection{Strategic formulation}

The last process of the development of the strategy is the strategic formulation. It contains three major topics.

a) Formulation of the strategy

b) Selection of the strategy

c) Preparing the communication of the strategy

\subsection{Formulation of the strategy}

The literature on strategy formulation and development is overwhelming and worth its own dissertation. But whatever methodology is used, the outcome from any strategy formulation approach is to develop a direction that differentiates the company's position and offering from those of its competitors so that it can create a sustainable 
competitive advantage that leads to superior financial performance. (Kaplan \& Norton, The Execution Premium, 2008)

\subsection{Selection of the strategy}

The strategic map framework (see figure 4) can support the process of the selection of the various strategic approaches.

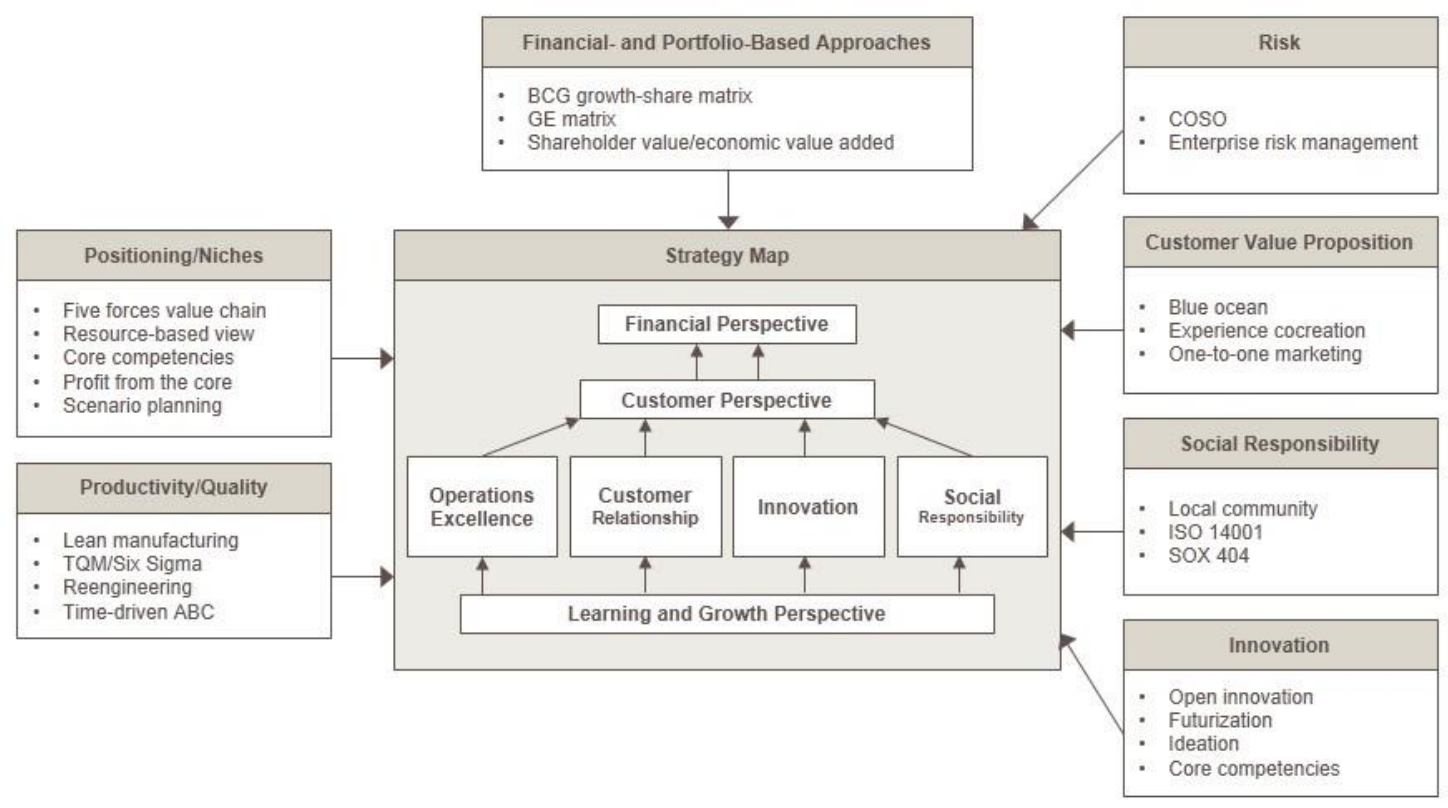

Figure 4: strategic map for strategy selection

\subsection{Preparing the communication of the strategy}

Kaplan mentioned two tools for the preparation of the communication and the preparation of the step 2 "plan the strategy" in his system.

\subsection{OAS Statement}

After selecting the strategy a communication plan needs to be set up to communicate to managers and employees. A good statement of the strategy should 
contain three fundamental elements (Objective / Advantage / Scope) (Collis D. , 2008). The objective is similar to the vision statement and it contains a quantitative goal. Advantage represents what the enterprise will do differently, better, or uniquely compared with competitors. Scope defines the market segment in which the enterprise intends to compete and win. (Kaplan \& Norton, The Execution Premium, 2008)

\subsection{Strategy Direction Statement}

The executive team can capture the creativity of the strategy development process and carry it forward using a strategy direction statement, before moving to the planning process (Kaplan \& Norton, The Execution Premium, 2008). The strategy direction statement spawns three components that are critical to the subsequent development of detailed plans. (Strategic objectives, Do-wells and Preliminary measures) (see figure 5) (Kaplan \& Norton, The Execution Premium, 2008)

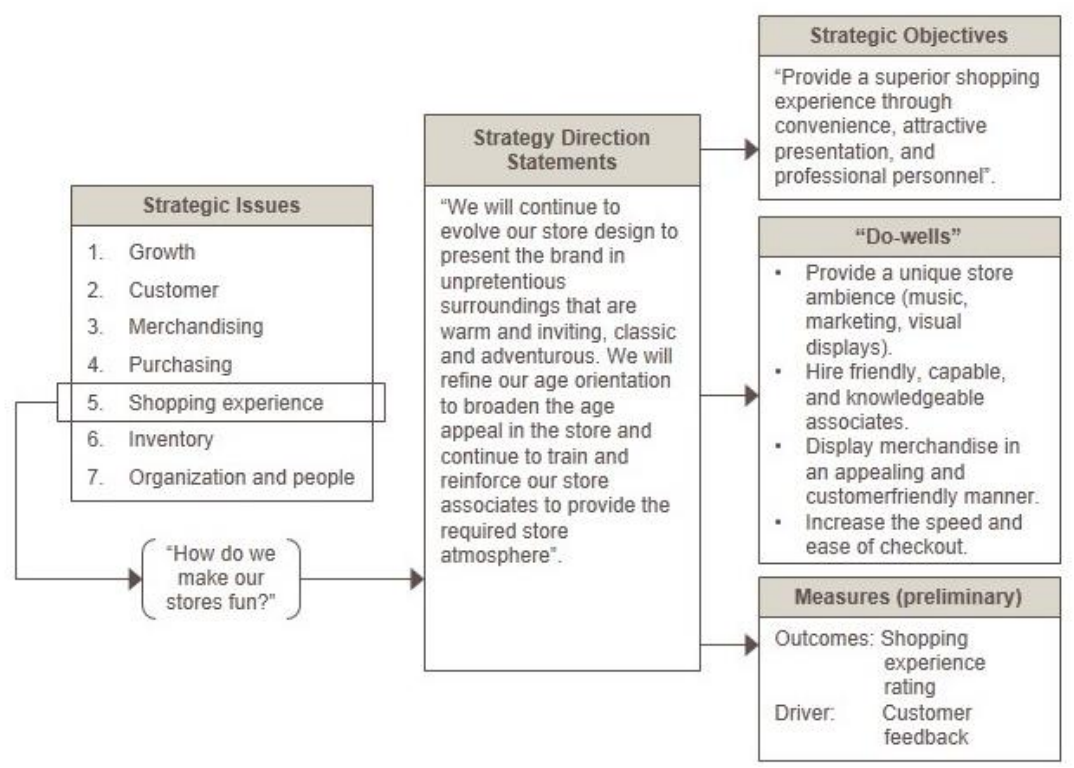

Figure 5: Strategic Formulation Guidelines 


\subsubsection{Step 2: Plan the strategy}

The next step in Kaplan's system is planning the strategy. This process converts statements of strategic direction into specific objectives, measures, targets, initiatives, and budgets that guide actions and align the organization for effective strategy execution. (Kaplan \& Norton, The Execution Premium, 2008)

It is based on two main processes.

a) Setting the strategic map including the definition of measures and targets

b) Launching the strategy into motion in form of strategic initiatives portfolios including the funding of the strategies and establishing the accountability. Therefore the second step is the entry into strategy execution.

\subsubsection{Strategy Maps}

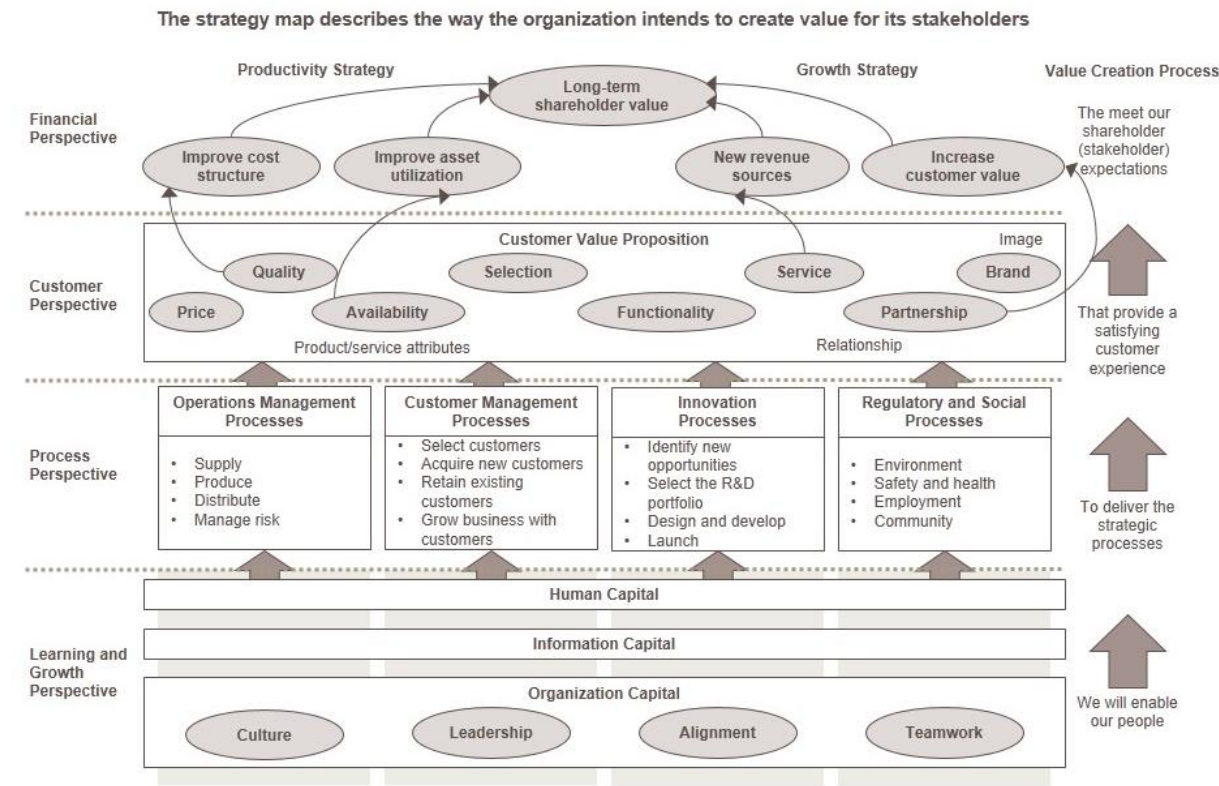

Figure 6: Strategy map

The strategy map as shown in figure 6 provides an architecture for integrating the strategies and operations. Kaplan constructed strategy maps upon strategic themes, collections of related strategic objectives within the map. Most of the strategic themes 
are vertical combinations of objectives that originate in the process perspective, where the strategy is executed. A process-based strategic theme can connect upward to customer and financial outcomes, as well as downward to the enabling objectives in the learning and growth perspective. (Kaplan \& Norton, The Execution Premium, 2008) This construction from Kaplan is based on his experiences with integrating balanced score cards into companies. The concept of the BSC method perfectly fits as a basis for his theory about setting up the strategy map.

Strategic themes split a strategy into several distinct value-creating processes. (Kaplan \& Norton, The Execution Premium, 2008)

A strategy map, organized by several parallel strategic themes, which generally deliver their benefits over different time periods, enables companies to simultaneously manage short, intermediate, and long-term value-creating processes. Strategy maps provide a clear picture of both the desired outcomes of the strategy (in the financial and customer perspectives) and the critical processes and enabling infrastructure (people, systems, and culture) required to achieve those outcomes.

The themes more clearly indicate the causal hypotheses within the strategy and also provide a powerful structure for resource allocation, accountability, alignment, and reporting. (Kaplan \& Norton, The Execution Premium, 2008)

\subsubsection{Measures and targets}

\subsection{Selecting Measures}

The next step in the strategy planning process establishes measures and targets for each objective. 
The act of measurement reduces the inherent ambiguity of language. Measures and associated targets express the objective in specific terms and enable the tracking of the organization's progress in achieving that strategic objective. (Kaplan \& Norton, The Execution Premium, 2008)

The balanced score card system provides with his methods a best-practice way to define and setup these measures and targets. (figure 7)

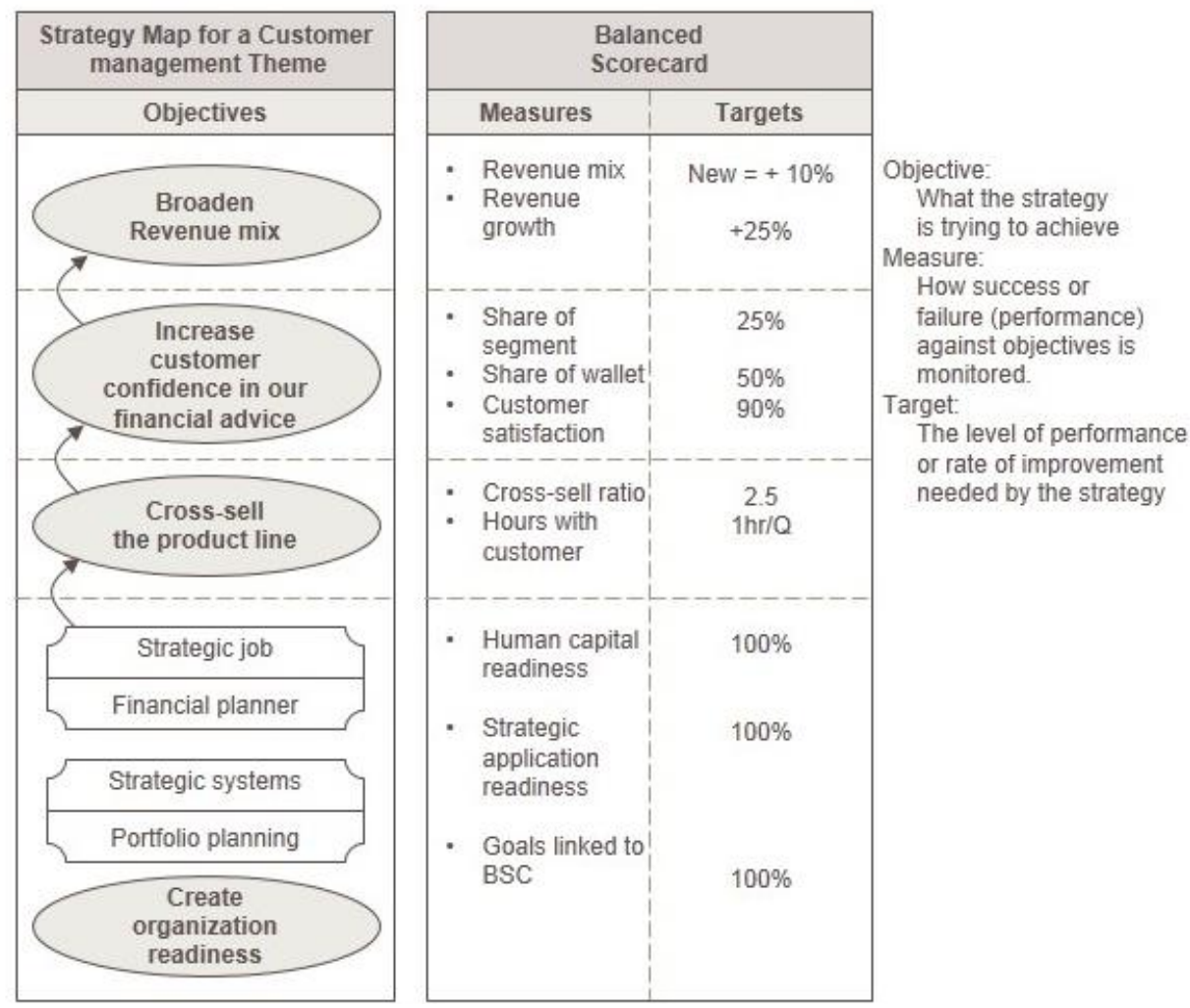

Figure 7: BSC method for definition of measures and targets

\subsection{Selecting targets}

Targets need to focus on closing company value gaps and achieve the overcome specified in its vision. Kaplan provides two techniques facilitate target setting:

Split the overall value gap into targets for each strategic theme, and set targets within each theme based on the cause-and-effect logic of the strategy map. 
2.1.2.2.2.1 Assigning the value gap to strategic themes

In the vision statement the leader sets a high-level target for the organization. The target creates a value gap between aspiration and current situation and the goal of the strategy is to close this value gap. The targets established for each theme reflect the theme's relative impact on helping create and deliver the various components of the strategy. (See figure 8) (Kaplan \& Norton, The Execution Premium, 2008)

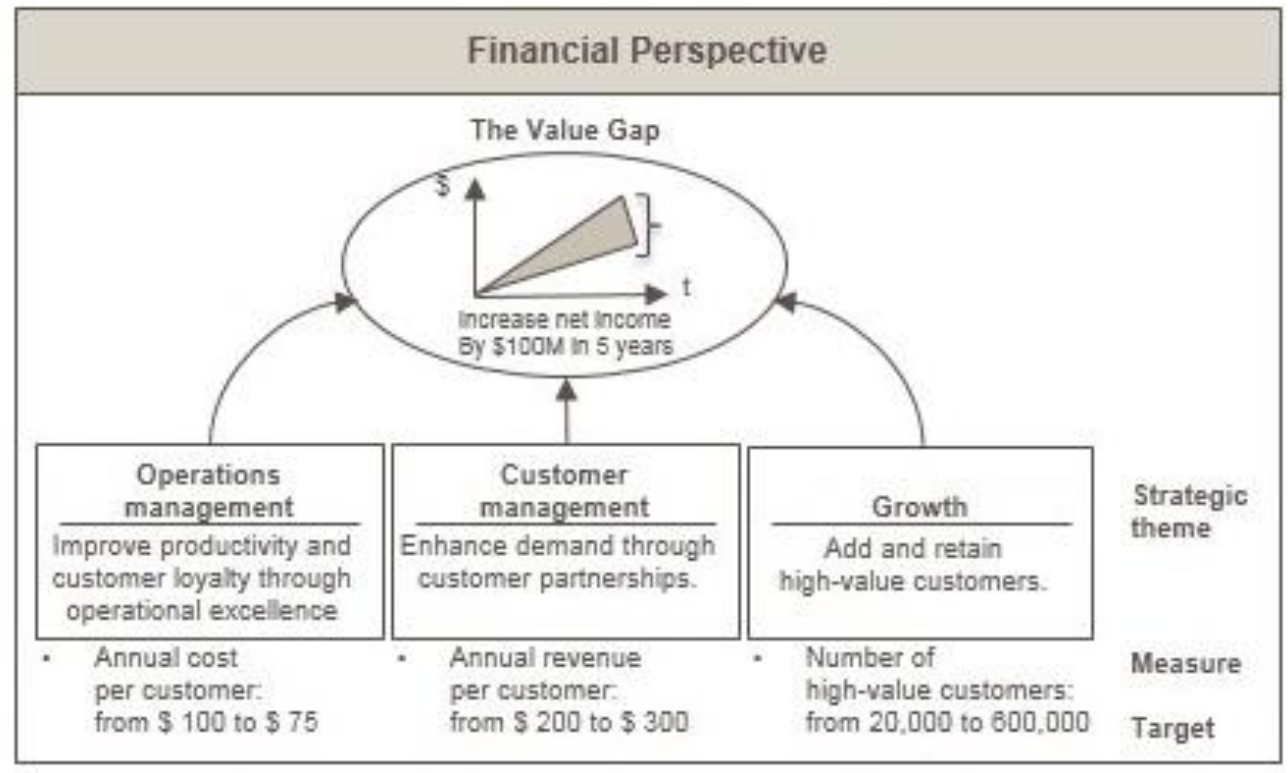

Figure 8: Example at Customer Bank: Value GAP and target setting

\subsection{Using Cause-and-effect logic for setting targets}

The targets for each strategic theme need to be further subdivided into targets for the strategic objectives within the theme. Each target for objective should be related to targets for other theme objectives in a chain of cause-and-effect logic as shown in figure 9. The cause-and-effect provide a bottom-up, clear, logical test of the strategy's feasibility. 


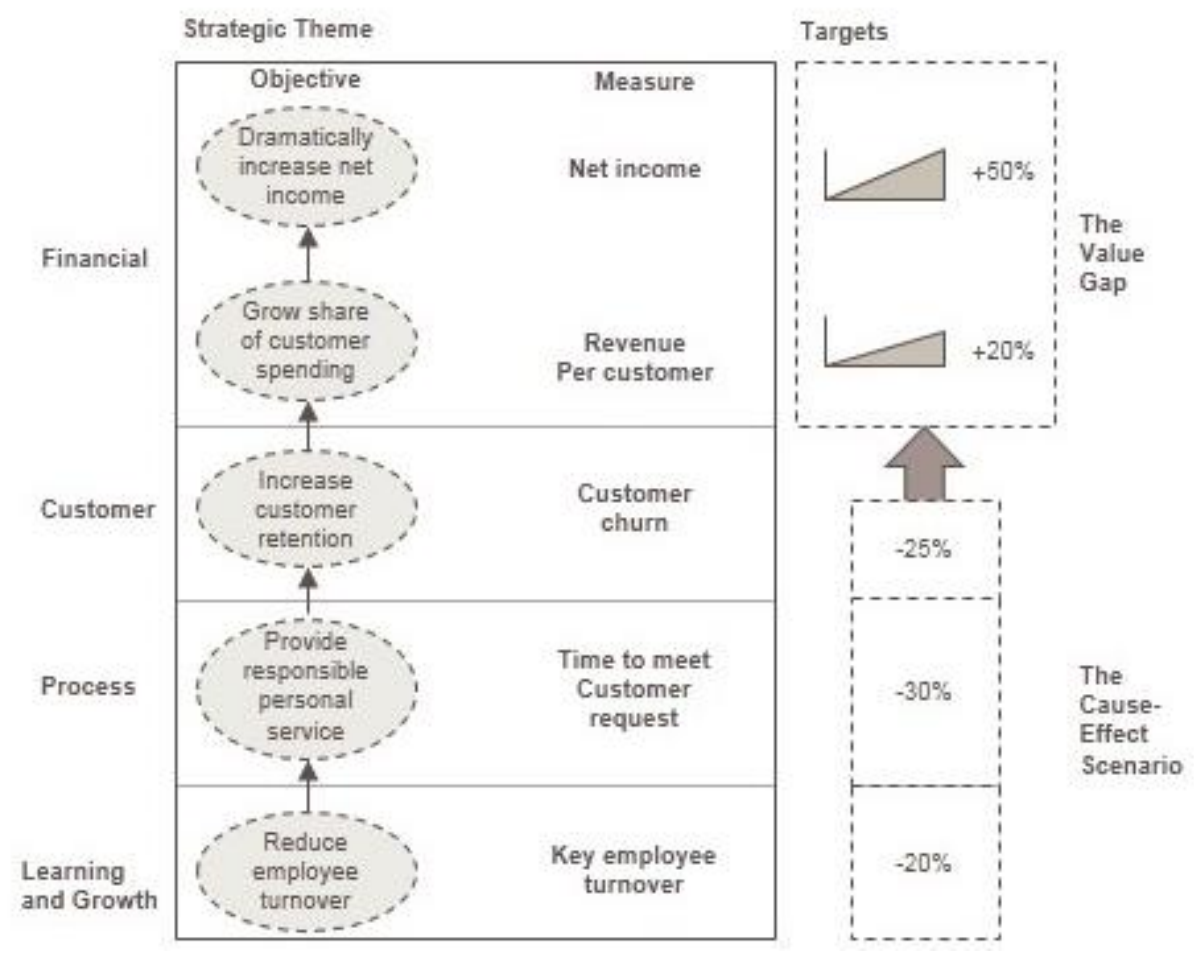

Figure 9: Cause-and-Effect-Logic

\subsection{Benchmarking Targets}

External benchmarks for performance measures can be useful, but they need to be treated with care to ensure that the company's circumstances are comparable to the conditions under which the external performance occurred. (Kaplan, Limits to Benchmarking - Balanced Scorecard Report, 2005) External benchmarks would likely be available for measures in all four perspectives. Internal Benchmarking could be performed by companies with large numbers of homogeneous outlets, such as retail-store chains, hotels, banks, and quick-service restaurants, can use statistical analysis to dentine their targets for processes and employee capabilities. (Kaplan \& Norton, The Execution Premium, 2008) 


\subsubsection{Launching the strategy into motion}

In this chapter Kaplan gets into the first steps of execution. The predefined targets represent what the organization wants to accomplish and strategic initiatives represent the how. Strategic initiatives are the collections of finite-duration discretionary projects and programs, outside the organization's day-to-day operational activities, that are designed to help the organization achieve its targeted performance. Organizations use three processes to manage their portfolios of strategic initiatives, as summarized in

figure 10. (Kaplan \& Norton, The Execution Premium, 2008)

\begin{tabular}{|c|c|c|c|}
\hline $\begin{array}{c}\text { Initiative } \\
\text { Management } \\
\text { Process }\end{array}$ & Objective & Barriers & $\begin{array}{l}\text { Enabling } \\
\text { Tools }\end{array}$ \\
\hline $\begin{array}{l}\text { 1. Choose strategic } \\
\text { initiatives } \\
\text { What action } \\
\text { programs does our } \\
\text { strategy need? }\end{array}$ & $\begin{array}{l}\text { To define the portfolio } \\
\text { of initiatives needed to } \\
\text { close each of the } \\
\text { performance gaps }\end{array}$ & $\begin{array}{l}\text { Strategic investments } \\
\text { are justified on a } \\
\text { stand-alone basis in } \\
\text { different parts of the } \\
\text { organization }\end{array}$ & $\begin{array}{l}\text { Portfolios of } \\
\text { initiatives for each } \\
\text { strategic theme }\end{array}$ \\
\hline $\begin{array}{l}\text { 2. Fund the Strategy } \\
\text { How do we fund } \\
\text { our initiatives? }\end{array}$ & $\begin{array}{l}\text { To provide a source of } \\
\text { funding for strategic } \\
\text { initiatives that is } \\
\text { separated from the } \\
\text { operational budget }\end{array}$ & $\begin{array}{l}\text { Cross-business portfolio } \\
\text { funding is contrary to } \\
\text { hierarchical, } \\
\text { departmental structure } \\
\text { of the budgeting process }\end{array}$ & $\begin{array}{l}\text { - STRATEX } \\
\text { - Prioritized } \\
\text { initiatives }\end{array}$ \\
\hline $\begin{array}{l}\text { Establish } \\
\text { Accountability } \\
\text { Who will lead the } \\
\text { execution of the } \\
\text { strategic initiatives? }\end{array}$ & $\begin{array}{l}\text { To establish } \\
\text { accountability for } \\
\text { execution of cross- } \\
\text { business strategic } \\
\text { themes }\end{array}$ & $\begin{array}{l}\text { Executive team } \\
\text { members are generally } \\
\text { responsible for } \\
\text { managing within } \\
\text { functional or business } \\
\text { unit silos }\end{array}$ & $\begin{array}{l}\text { - Executive theme } \\
\text { owners } \\
\text { - Theme teams }\end{array}$ \\
\hline
\end{tabular}

Figure 10: launching strategy into motion

\subsection{Strategic initiatives}

Kaplan is very clear about the fact that initiatives should not be selected in isolation from each other. Achieving a strategic objective in the customer or financial 
perspective generally requires multiple and complementary initiatives from various parts of the organization. (Kaplan \& Norton, The Execution Premium, 2008)

Kaplan continues to recommend, as shown in figure 11, that each nonfinancial objective has at least one initiative to drive its achievement but also that the initiatives be bundled for each strategic theme and considered as an integrated portfolio.

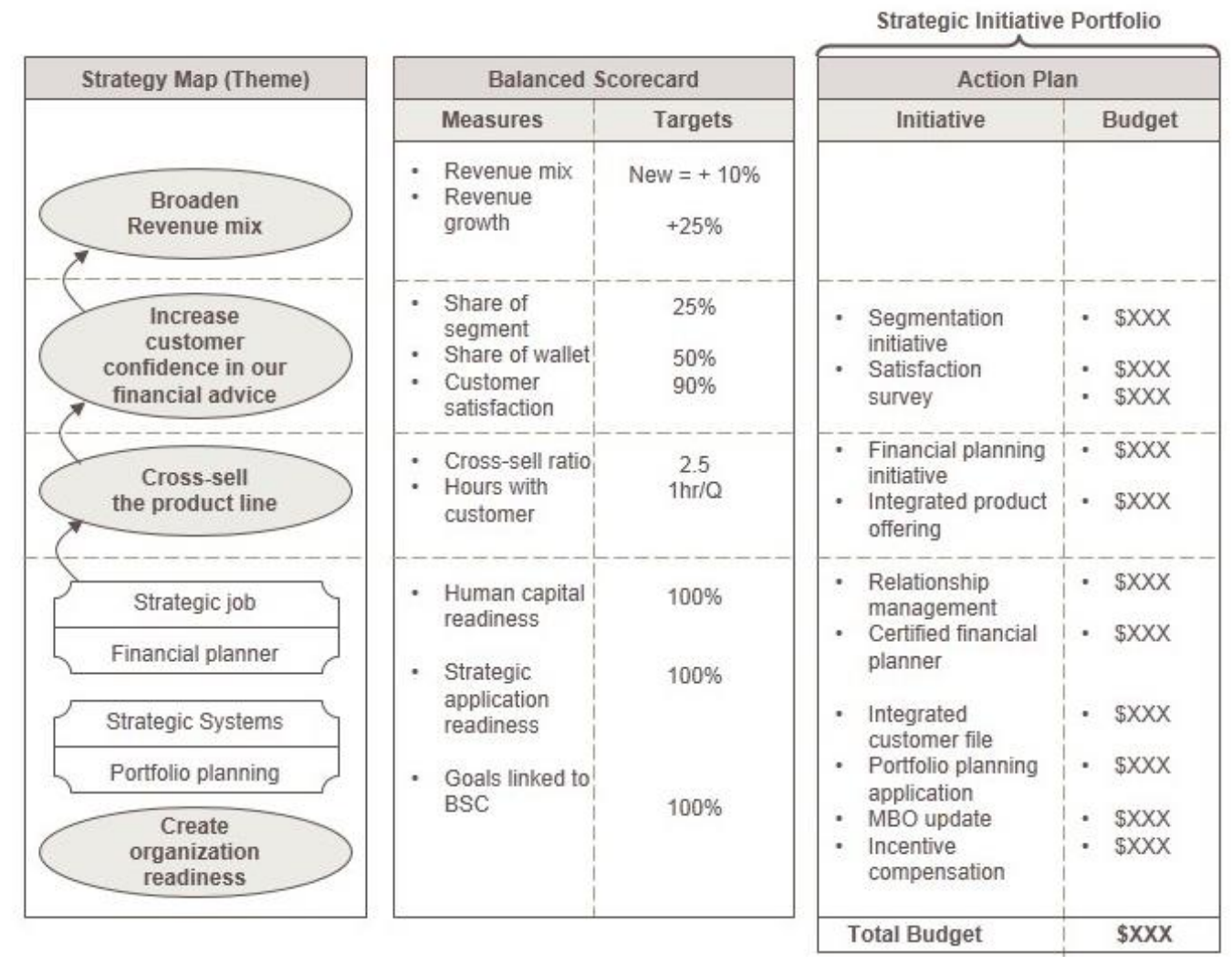

Figure 11: Strategic Initiative Portfolio

A result of Kaplan's experience is that companies get an immediate benefit from creating their first strategy map when they perform an initiative review and rationalization process. Managers should encourage and solicit employees to generate new initiative ideas, because some of the best initiative ideas come from frontline employees. A designated group reviews all the new proposals that have been accumulated and conducts a formal assessment and ranking processes. The team then 
applies a formal process to evaluate and rank the initiatives. The project team refers all the initiatives and their scores to a leadership team for final discussion, debate and selection. The final approved list contains the critical few strategic initiatives that will be funded to drive performance. Strategic initiatives are the short-term actions that launch an organization on a trajectory toward achieving its vision. Each strategic theme requires complete portfolios of strategic initiatives if its ambitious performance targets are to be achieved.

\subsection{Fund the strategy}

Often the funding for strategic initiatives must come from existing budgets, so Kaplan stated that the success of the strategy will be put in jeopardy, because they must compete for resources with other projects. Resources - people and funding - must be provided for each strategic theme's portfolio of initiatives.

Companies classify spending into either operating expenses (OPEX) or capital expenses (CAPEX) and a third category, strategic expenses (STRATEX), should be created to segregate the resources required to implement initiatives that deliver longterm benefits. (Kaplan \& Norton, The Execution Premium, 2008)

STRATEX is designed to enhance the intangible assets that provide organizational capabilities, such as training and customer databases.

Kaplan and his team recommends that senior executive team determine subjectively, from their experience and best judgment, a top-down funding level for all strategic initiatives.

Ideally, the targeted spending on strategic initiatives takes into account the benefits from funding future performance and balancing these against the risk of spending too much on initiatives whose future benefits do not yield an adequate return. 
STRATEX funding for the portfolio or cross-business initiatives is so important that it deserves a separate authorized line item in the company's internal budget or financial forecast. The separate STRATEX line item allows the organization to balance long- and short-term considerations in its financial forecasting and operating processes. (Kaplan \& Norton, The Execution Premium, 2008)

Figure 12 shows the general approach of integrating STRATEX into the budgeting process. Figure 13 shows a detailed view on this process.

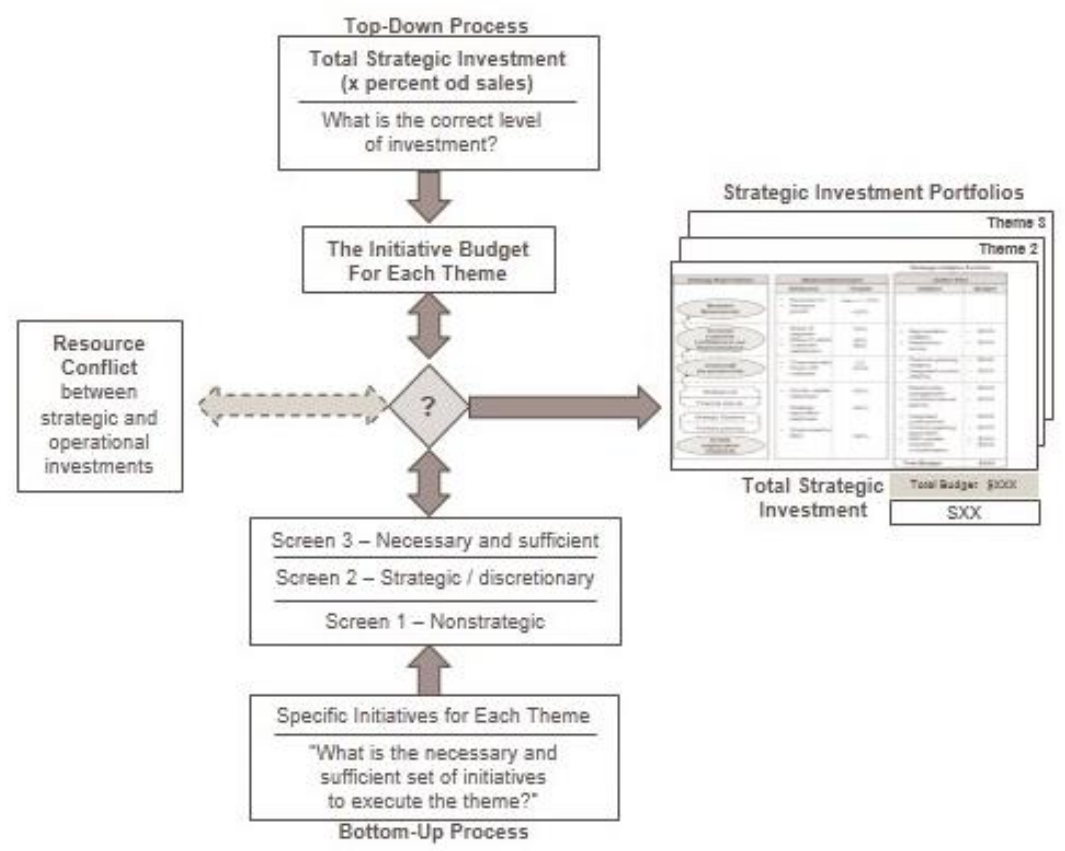

Figure 12: General View of Budgeting with STRATEX 


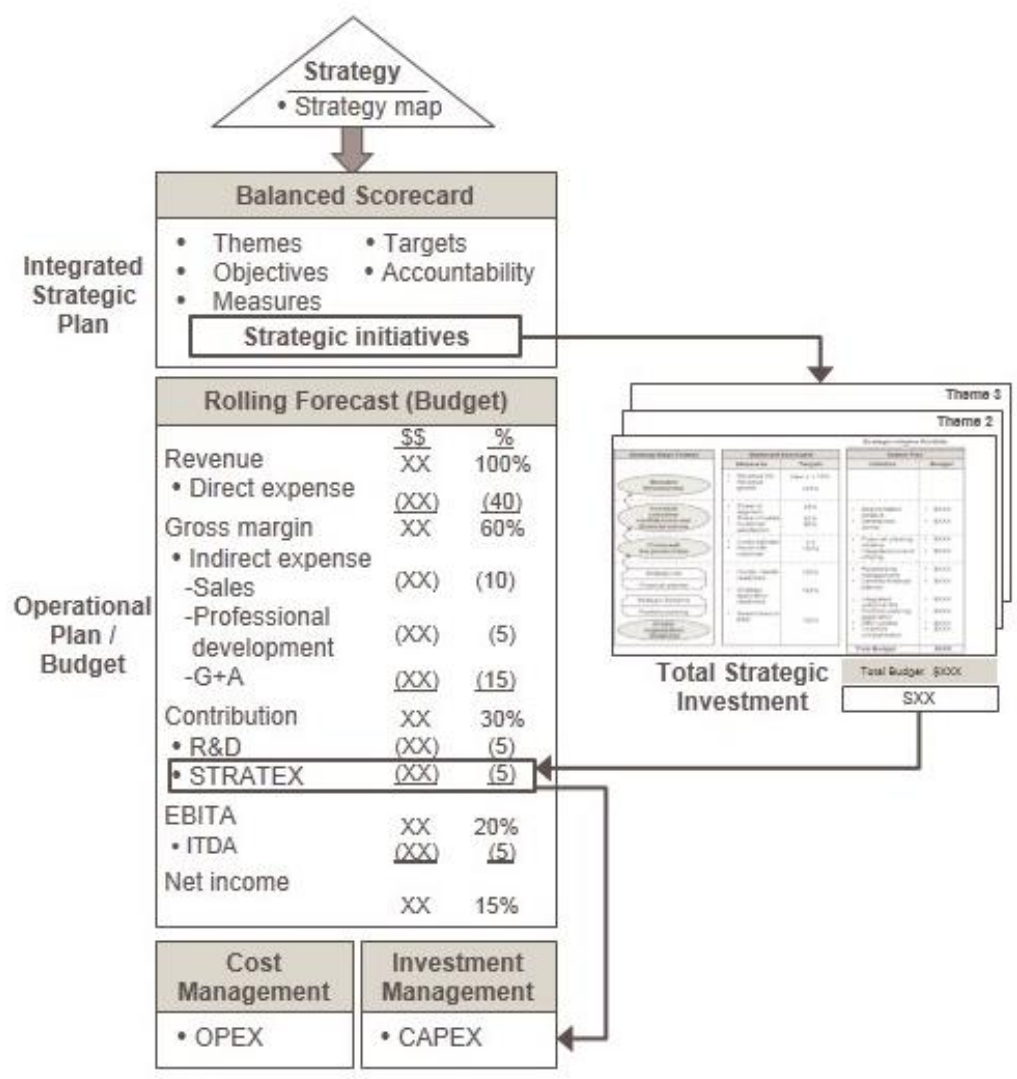

Figure 13: Detailed View of Budgeting with STRATEX

\subsection{Establish Accountability and responsibility}

Finally in the process of getting motion into the strategy the establishment of accountability and responsibility needs to be done. Kaplan stated two factors make this step a challenge: First, they do not fall within the existing responsibility of any senior executive, because most strategic themes cross functions and business units. Second the strategic themes are still plans and they do not produce results until the required changes are executed at the operational and process levels.

Companies assign some members of the executive team to be the owners of each strategic theme, giving the theme owners the "night jobs" of overseeing execution of 
the assigned strategic themes in addition to their day jobs. Kaplan shows in a bestpractice example a way how these challenge can be managed:

Each theme owner leads a theme team whose job is to link the theme's strategic objectives to operational tasks. They don't have authority over functions or businesses. The theme team has primary responsibility for identifying and funding (from the STRATEX allocation) the portfolio of initiatives required to execute the theme's strategy. After the selecting and allocating resources, it identifies who will be assigned the task of accomplishing each initiative. Often, the theme team can assign this responsibility to an existing or organizational unit. The responsibility of some initiatives which are cross functional, remains with the theme team or is assigned to a centralized project management office.

By giving high-level authority and accountability to senior executives (the theme owners), companies can achieve holistic implementation of its portfolio of strategic initiatives. The theme team also can translate the high-level strategic process objectives into detailed and actionable sub processes. The final process of linking strategic themes and short-term initiatives requires that the senior management team periodically review the execution and results of the strategic initiative portfolios.

\subsubsection{Step 3: Align the organization}

After Step one Development of the strategy and step two planning the strategy with step three Kaplan focus on the main issue of his book providing a management system for aligning strategy with business operations. A first issue in doing this is that most organizations consist of multiple business and support units, so the management system must address how strategy is integrated across these diverse organizational units. (Collis \& Montgomery, 1998) In addition to this, the system must align 
employees with the strategy. Summarized aligning the organization needs three main processes as shown in Table 1. (Kaplan \& Norton, The Execution Premium, 2008)

\begin{tabular}{|c|c|c|c|}
\hline $\begin{array}{l}\text { Alignment } \\
\text { Process }\end{array}$ & Objective & Barriers & $\begin{array}{l}\text { Enabling } \\
\text { Tools }\end{array}$ \\
\hline $\begin{array}{l}\text { 1. Align Business } \\
\text { Units } \\
\text { How do we align } \\
\text { business units to } \\
\text { create corporate } \\
\text { synergies? }\end{array}$ & $\begin{array}{l}\text { Cascade and embed } \\
\text { corporate strategy into } \\
\text { business unit } \\
\text { strategies. }\end{array}$ & $\begin{array}{l}\text { Business unit strategies } \\
\text { typically are developed } \\
\text { and approved } \\
\text { independently, without } \\
\text { the guidance of a } \\
\text { corporate perspective: } \\
\text { lack of integration } \\
\text { across business units. }\end{array}$ & $\begin{array}{l}\text { - Cascading of strategy } \\
\text { maps to business units } \\
\text { - Vertical and horizontal } \\
\text { alignment }\end{array}$ \\
\hline $\begin{array}{l}\text { 2. Align Support Units } \\
\text { How do we align } \\
\text { support units to } \\
\text { business unit and } \\
\text { corporate strategies? }\end{array}$ & $\begin{array}{l}\text { Ensure that each } \\
\text { support unit has a } \\
\text { strategy that enhances } \\
\text { the performance of } \\
\text { corporate and } \\
\text { business unit } \\
\text { strategies. }\end{array}$ & $\begin{array}{l}\text { Support units treated as } \\
\text { "discretionary expense } \\
\text { centers," with goals to } \\
\text { minimize costs rather } \\
\text { than to support } \\
\text { enterprise and business } \\
\text { unit strategies. }\end{array}$ & $\begin{array}{l}\text { - Service-level } \\
\text { agreements } \\
\text { - Support unit strategy } \\
\text { maps and scorecards }\end{array}$ \\
\hline $\begin{array}{l}\text { 3. Align Employees } \\
\text { How do we motivate } \\
\text { employees to help } \\
\text { us execute the } \\
\text { strategy? }\end{array}$ & $\begin{array}{l}\text { All employees } \\
\text { understand the } \\
\text { strategy and are } \\
\text { motivated to help } \\
\text { successfully execute } \\
\text { the strategy. }\end{array}$ & $\begin{array}{l}\text { Most employees are not } \\
\text { aware of or do not } \\
\text { understand the strategy. } \\
\text { Their objectives and } \\
\text { incentives focus on } \\
\text { local, typical } \\
\text { performance, not } \\
\text { strategic objectives. }\end{array}$ & $\begin{array}{l}\text { - Formal strategy } \\
\text { communication } \\
\text { program } \\
\text { - Employee objectives } \\
\text { with clear line of sight } \\
\text { to strategic objectives } \\
\text { - Incentive and reward } \\
\text { programs } \\
\text { - Competency } \\
\text { development programs }\end{array}$ \\
\hline
\end{tabular}

Table 1: Align the organization process

Kaplan states that the management of the alignment needs to be done in a process framework because alignment, like the other strategy execution processes, crosses organization boundaries. To be effective, alignment requires the integration and corporation of individuals from different organizational units.

\subsubsection{Align Business Units}

Corporations achieve synergies from their collection of operating and business units in a variety of ways. The four perspectives of the BSC provide a useful taxonomy for describing the various sources of corporate synergies. (see Figure 14) (Kaplan \& Norton, The Execution Premium, 2008) 


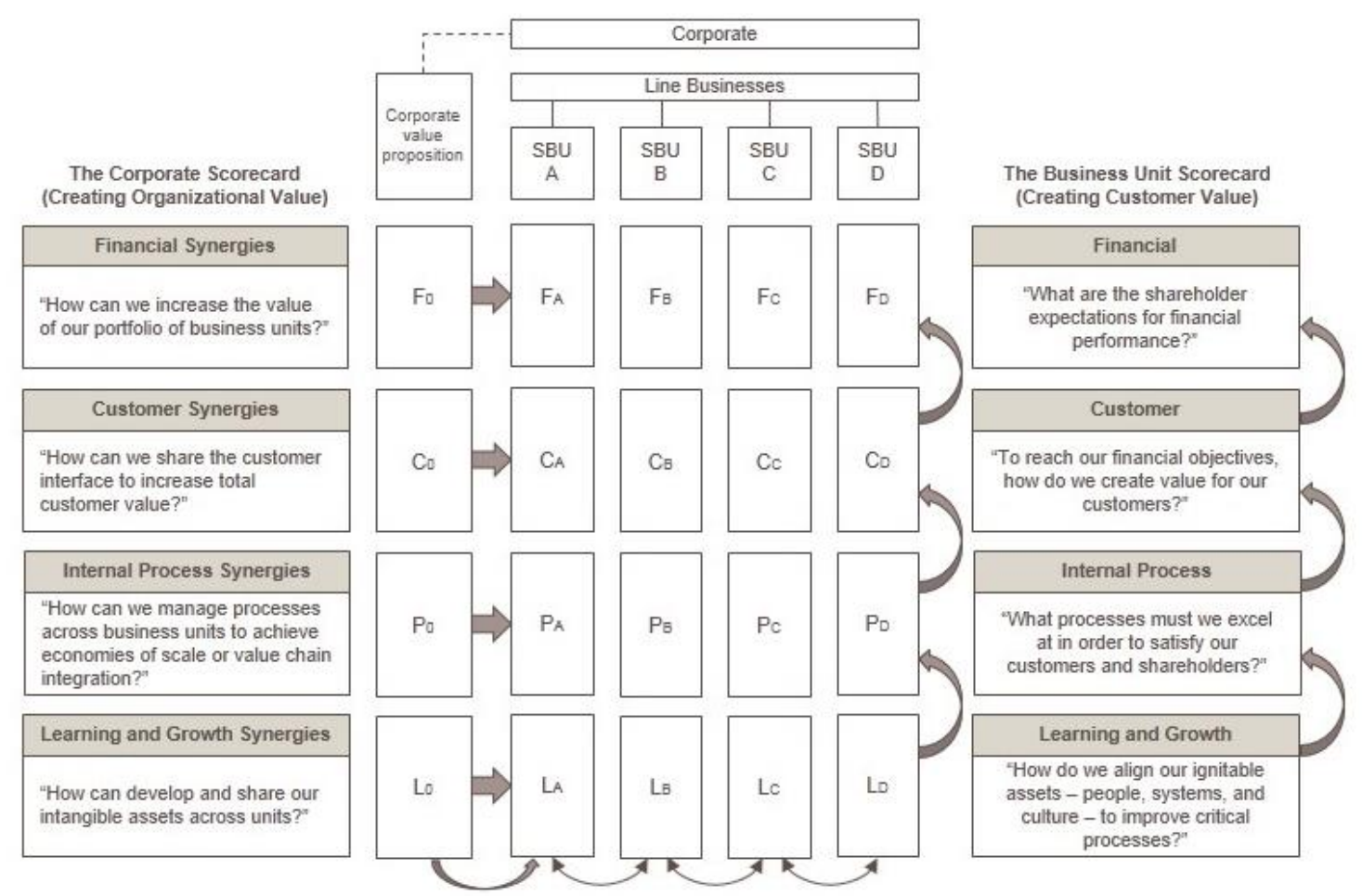

Figure 14: BSC for aligning the organization

In the strategy map and scorecard the theory in form of how to generate additional value by having business units operate together is documented.

Once defined, the corporate strategy map can be cascaded to divisions, business and support units, and departments to coordinate the value-creating activities at all these organizational units as shown in Figure 15. (Kaplan \& Norton, The Execution Premium, 2008) 


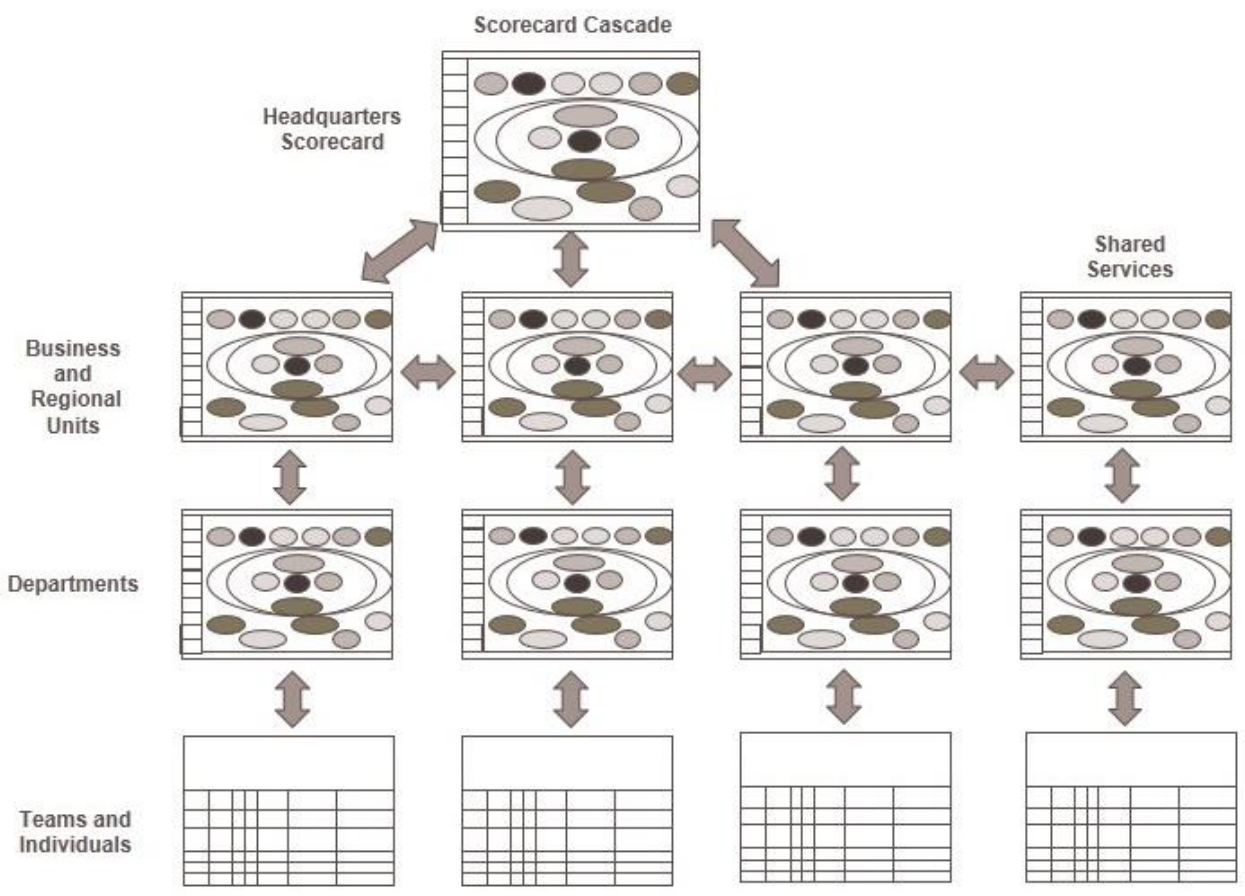

Figure 15: vertical and horizontal alignment

Kaplan stated, that between these two polar situations - complete operating unit autonomy and complete adherence to corporate-determined strategy and metrics - are the majority of other companies. Their strategy maps and scorecards of such operating units contain many objectives that are unique to local operations, but they also contain several that reflect corporate-level priorities and objectives shared with other operating units. The operating unit head must maintain a balance between local optimization, as if the unit were an autonomous company, and the unit's contribution to corporate and other business unit's objectives that generate the corporate synergies.

\subsubsection{Align Support Units}

Kaplan describes the framework for the aligning of support units as "Support and shared-service units, such as human resource, information technology, finance, and 
planning, develop their strategy maps and BSC to enhance the strategies of the operating units they support."

Support units follow a systematic set of processes to create alignment: First internal support units must understand the corporate and operating unit strategies. Next, they align their strategies with the business unit and corporate strategies by determining the set of strategic services to be offered. Often this is formulized with a service-level agreement, a performance contract between the support and business units.

The support units' financial perspective contains objectives that reflect how the unit contributes to the company's costs reduction, revenue growth, or asset utilization objectives.

In crafting the objectives on its strategy map and BSC, the support unit must identify how it contributes to the value-creating strategies of its business unit partners and any other constituencies it services. (See figure 16) (Kaplan \& Norton, The Execution Premium, 2008)

\subsubsection{Align Employees}

Ultimately, effective strategy execution requires that employees be personally committed to helping their enterprise and unit achieve strategic objectives. The process to align employees with the strategy requires three steps:

a) Communicate and educate employees about the strategy.

b) Link employee's personal objectives and incentives to the strategy

c) Align personal training and development programs to provide employees with the knowledge, skills, and competencies they need to help implement the strategy. 


\subsection{Communicate and Educate About the Strategy}

Communication of mission, values, vision, and strategy is the first step in creating motivation among employees. Executives can explain with using a Strategy map and BSC what the organization wants to accomplish and how it intends to realize its strategic outcomes. (Kaplan \& Norton, The Execution Premium, 2008)

Communication also helps share the culture. Cultural massages might include a commitment to performance and accountability, a focus on customers, and a relentless passion for continuous improvement, or creativity and innovation.

Communication by leaders is critical. Employees cannot follow if executives do not lead. Managers' report that they must communicate seven times, in seven different ways. The communication best practices in the most successful enterprises have certain characteristics, in which senior executives personally lead the communication process. (Johnson, 2007)

\subsection{Link Personal Objectives and Incentives to the Strategy}

Kaplan stated that the most successful BSC implementations have occurred, when organizations skillfully melded the intrinsic motivation emanating from its leadership and communication program with the extrinsic motivation created by aligning personal performance objectives and incentive compensation.

After receiving communication, education, and training about the strategies of their unit and enterprise, employees develop personal objectives that are aligned with the strategic objectives.

Annually, employees validate their personal strategic objectives with the help of their supervisors and HR professionals. Typical incentive plans include two or three kinds of awards: 
a) an individual award based on achieving targets established annually for each employee's personal objectives,

b) an award based on the employee's business unit,

c) an award tier for divisional or enterprise performance.

(Kaplan \& Norton, The Execution Premium, 2008)

\subsection{Develop Employee Competencies}

Employees must develop the competencies - the knowledge, skills, and values. The development of knowledge and skills to employees through training and development programs, along with career planning is a proper way to lift up the competency profiles of the employees.

Instilling values requires a combination of taking good inputs through careful recruitment and selection programs to inspire the behaviors that the corporation desires. (Kaplan \& Norton, The Execution Premium, 2008)

\subsubsection{Step 4: Plan Operations}

The next step in Kaplan's management system is planning the operations. This step is the main foundation of the focus of his theories execution premium. It is the link between the strategy and the execution of it in form of operational business. Or otherwise the output of the plan in form of an operational plan is the basis for the execution. This output is strongly linked and influenced to the output of the first three steps, the strategic plan. Planning the operations has two main processes as shown in Table 2. (Kaplan \& Norton, The Execution Premium, 2008) 


\begin{tabular}{|c|c|c|c|}
\hline $\begin{array}{c}\text { Strategy Execution } \\
\text { Process }\end{array}$ & Objective & Barriers & $\begin{array}{c}\text { Representative } \\
\text { Activities }\end{array}$ \\
\hline $\begin{array}{l}\text { 1. Improve Key } \\
\text { Processes } \\
\text { What business } \\
\text { process changes } \\
\text { does the strategy } \\
\text { require? }\end{array}$ & $\begin{array}{l}\text { Ensure that changes } \\
\text { required by the } \\
\text { strategic themes are } \\
\text { translated to changes } \\
\text { in operational } \\
\text { processes }\end{array}$ & $\begin{array}{l}\text { No alignment between } \\
\text { strategic priorities and } \\
\text { quality and continuous } \\
\text { improvement programs }\end{array}$ & $\begin{array}{l}\text { - Total quality } \\
\text { management } \\
\text { - } \text { Business process } \\
\text { improvement } \\
\text { - Key success factors } \\
\text { - KPIs/dashboards }\end{array}$ \\
\hline $\begin{array}{l}\text { 2. Develop the } \\
\text { Resource } \\
\text { Capacity Plan } \\
\text { How do we link the } \\
\text { strategy to operating } \\
\text { plans and budgets? }\end{array}$ & $\begin{array}{l}\text { Ensure that resource } \\
\text { capacity, operational } \\
\text { plans, and budgets } \\
\text { reflect the directions } \\
\text { and needs of the } \\
\text { strategy }\end{array}$ & $\begin{array}{l}\text { Forecasts, budgets, and } \\
\text { operating plans } \\
\text { developed } \\
\text { independently from } \\
\text { strategic plan }\end{array}$ & $\begin{array}{l}\text { - Rolling forecasts } \\
\text { - } \text { Activity-based costing } \\
\text { model } \\
\text { - Resource planning } \\
\text { - Budgeting } \\
\text { (OPEX/CAPEX) } \\
\text { - Pro forma financials }\end{array}$ \\
\hline
\end{tabular}

Table 2: Main process in planning operations

In this chapter Kaplan shows the process for performing these two processes and also highlights the output of these two processes: the operating plan with its four major documents: dashboards, sales forecast, resource requirements and budgets.

\subsubsection{Improve Key Processes}

Strategy execution requires alignment and execution of both strategic initiatives and process improvement programs.

Quality and process improvement programs existed well before the introduction of the BSC. (TQM, lean management, just-in-time, six sigma) The reengineering movement occurred in the early 1990s, almost all enterprises were implementing quality and process improvement initiatives.

Organizations can use the strategic objectives on their strategy map and scorecards to enhance and align their process management program. Quality models often focus on local, tactical, and unlinked process improvement.

The BSC provides explicit causal links from quality and process improvements to successful outcomes for customers and shareholders. 
The cause-and-effect relationships in a strategy map and the strategic objectives on the BSC highlight the process improvements that are most critical for successful strategy execution. Aligning quality and process improvement programs with strategy starts with the value proposition. (Kaplan \& Norton, The Execution Premium, 2008)

\subsection{Identifying Strategic Processes for Improvement}

In Addition to improving existing processes, a newly created strategy map often identifies entirely new processes at which the company must excel. Quality and process improvement projects will generate the highest payoffs when they are selected based on criteria linked to the company's strategic objectives. Kaplan stated that companies should emphasize improving those processes that contribute the most to the success of the company's strategy.

\subsection{Strategic Versus Vital Processes}

\begin{tabular}{l|c|c|}
\multicolumn{2}{c}{ Strategic } & \multicolumn{2}{c}{ Process Classification } \\
\cline { 2 - 3 } $\begin{array}{l}\text { Balanced } \\
\text { Scorecard } \\
\text { assessment }\end{array}$ & $\begin{array}{c}\text { Improve to levels of } \\
\text { quality excellence }\end{array}$ & $\begin{array}{c}\text { Maintain high quality } \\
\text { levels }\end{array}$ \\
\cline { 2 - 3 } \multicolumn{1}{c}{ Vital } & $\begin{array}{c}\text { Improve to minimum } \\
\text { acceptable quality levels }\end{array}$ & $\begin{array}{c}\text { Potential to cut back } \\
\text { current investment }\end{array}$ \\
\cline { 2 - 3 } & \multicolumn{2}{c}{$\begin{array}{c}\text { Needs improvement } \\
\text { Quality assessment }\end{array}$}
\end{tabular}

Figure 16: Link between process improvement and BSC strategic priorities

Figure 16 shows the link between process improvement and BSC strategic priorities. The columns classify the organization's existing processes as either "excellent" or "need improvement" and the rows distinguish between processes identified on the BSC as "strategic" - contributing to the differentiation of the 
company's strategy - and those that are "vital" - necessary for the company's success but not creating a strategic difference.

The strategic processes will receive continual review and attention from senior management in their monthly strategy review meetings. These reviews are important component of what Bob Simons calls the company's interactive system.

The vital processes are also important, and the reporting and feedback on them with respect to the performance are included in Simon's diagnostic system. The diagnostic system conserves management attention by operating under management by exception.

\subsection{Define Priorities for process management}

First step of setting the priorities is to identify the gap between the existing process capabilities, developed to support the previous strategy, and the process performance required for the new offering. It is the goal to close this strategy gap by enhancing existing processes and introducing some entirely new ones.

The next step is to drill down to process management by identifying the key process objectives on the strategy map as shown in Figure 17. (Kaplan \& Norton, The Execution Premium, 2008) 


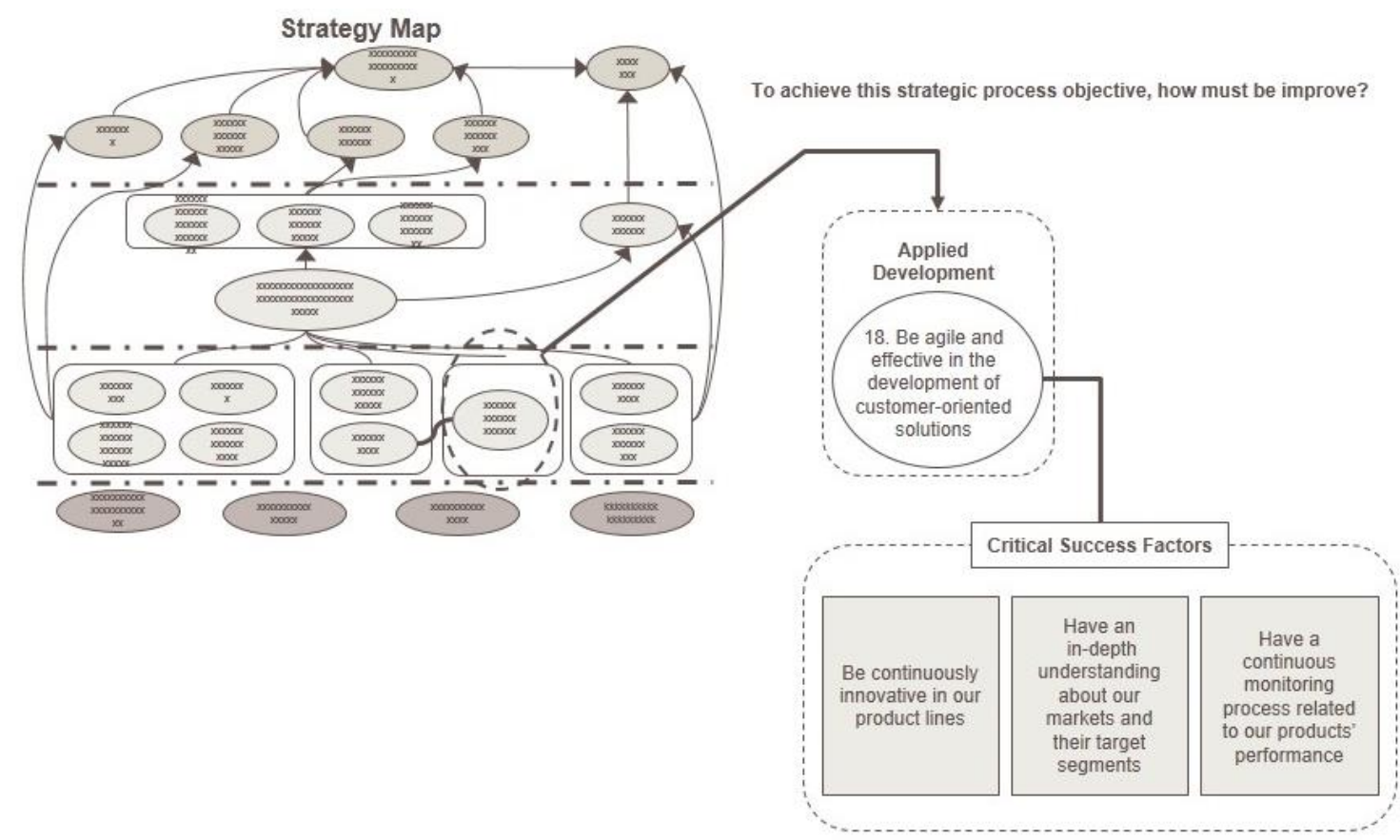

Figure 17: linking process management to BSC strategic processes

After that, the key performance (process) indicators (KPIs) that drive process excellence, needs to be identified. The BSC metrics are outcome (or lagging) indicators, which provide feedback.

In the next step, the critical success factors (CSFs) will be set up. Selecting the CSFs along with metrics to make the CSFs operational is the major focus in this process. The metrics can be displayed on a process dashboard to improve the performance of subprocesses. Dashboard metrics are the operational performance indicators that lead, via a cause-and-effect relationship, to process excellence. This complete process is shown in Figure 18. (Kaplan \& Norton, The Execution Premium, 2008) 


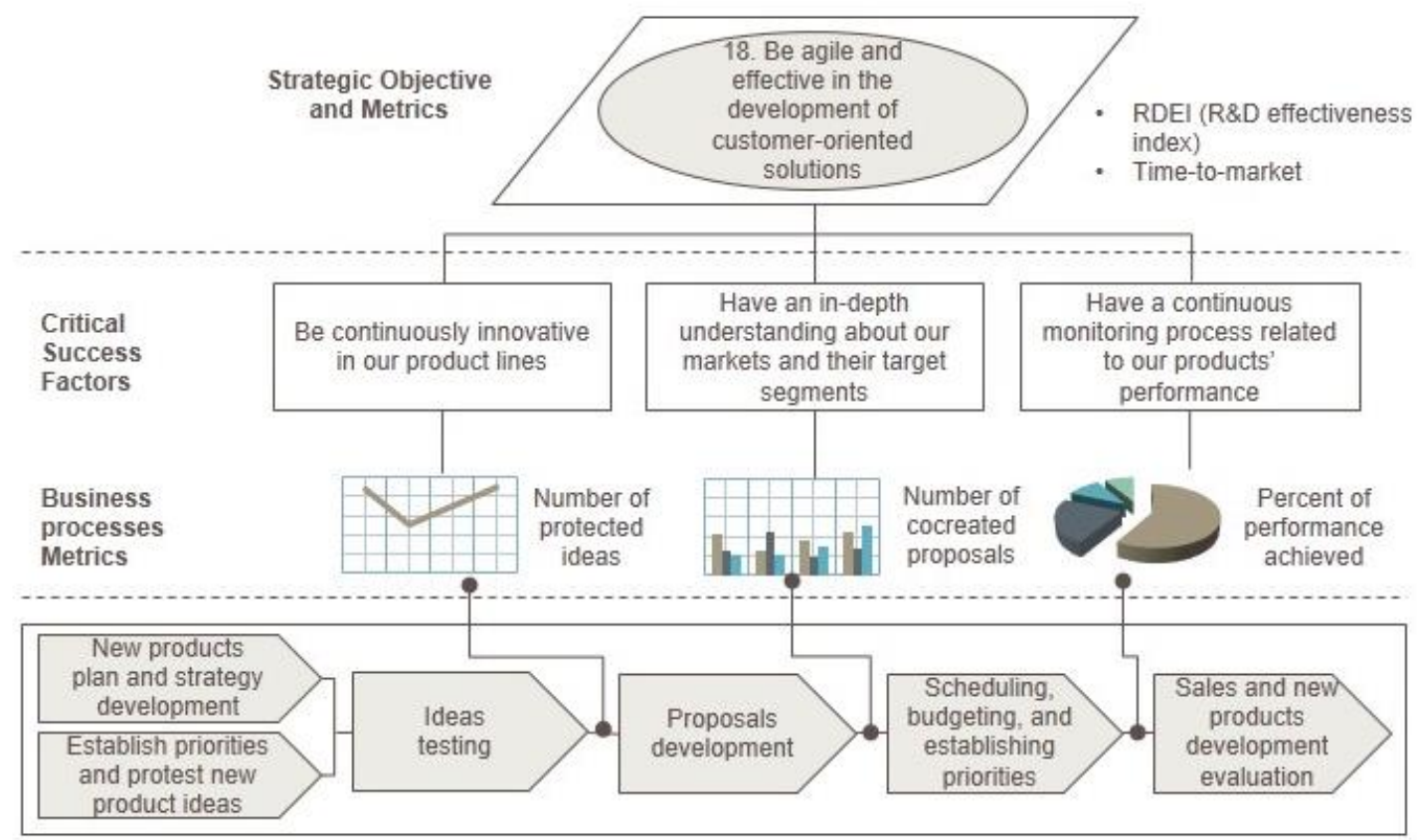

Figure 18: BSC linked with CSF and metrics

\subsection{Dashboards}

Enhancing the process improvement by designing and deploying local operational dashboards is a proper way for monitoring and visualization of the improvement status in process management. Dashboards are a collection of key indicators that provide feedback on local process performance. Although all processes benefit from systematic measurement and reporting, dashboards are most effective when they highlight the processes from the unit’s BSC process perspective. Dashboards differ from BSC in several ways. Dashboards are operational, not strategic. They focus on process metrics that employees can affect in their daily actions. BSC metrics are outcomes, which are updated monthly or quarterly, dashboards can reflect daily and even hour-by-hour performance. (see Figure 19). (Eckerson, 2006) 


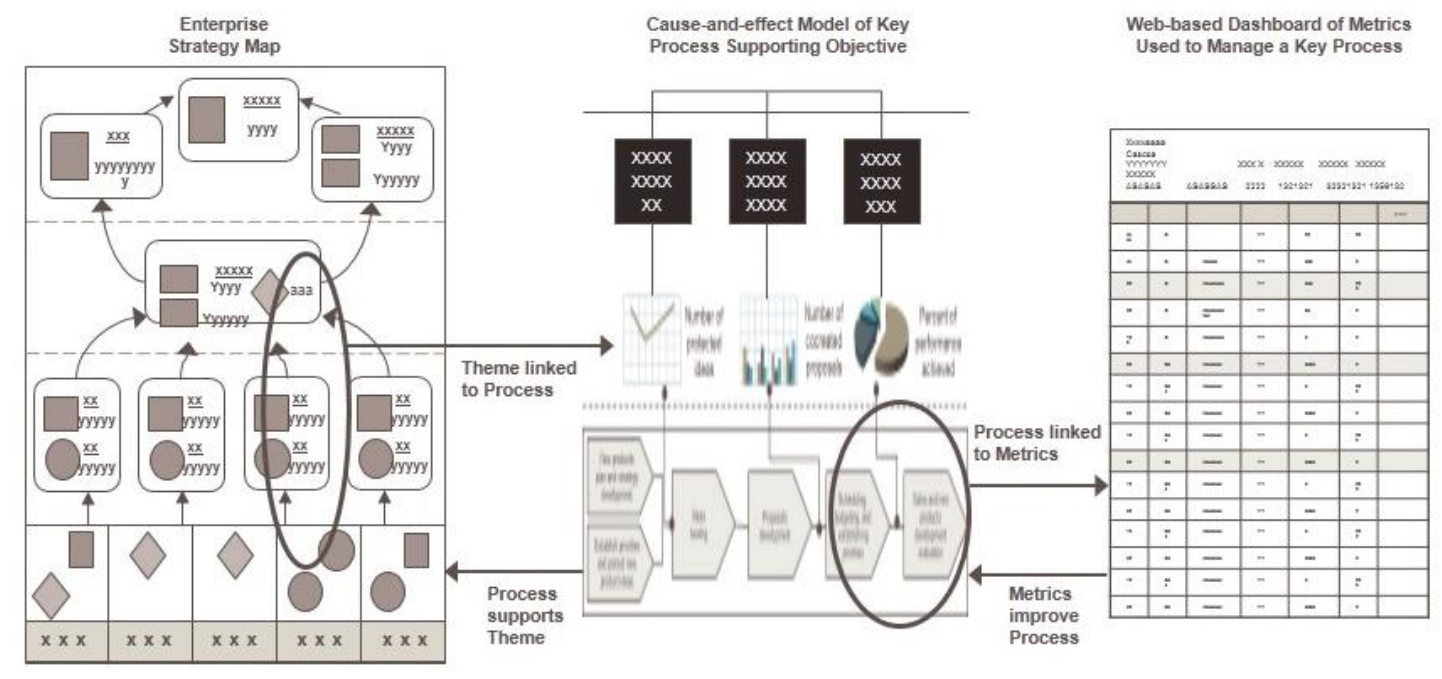

Figure 19: Link between Strategy Map, cause-and-effect model and dashboards

Such rapid feedback helps employees learn from their experience. Dashboards also focus on local departmental, functional, and process performance, in contract to the cross-business and cross-functional outcome indicators on the BSC. Dashboards data also are prime informational input for focused operational review meetings.

Finally and additional to the dashboards process improvement activities are no local projects. A leverage of the process improvement capabilities by sharing bestpractice experiences across all organizational unit is needed for an optimal overview.

\subsubsection{Develop the resource capacity plan}

In this chapter Kaplan presents an integrated approach for linking the strategic plan to forecasts for spending on operating and capital resources.

This process ensures that resource capacity, operational plans, and budgets reflect the direction and needs of the strategy.

Kaplan stated that the classic way of the budgeting process to coordinate and control the diverse business units has the following fatal weakness. 
- Creating a budget takes excessive time and money.

- A budget motivates managers to make lowball estimates of revenues and income for fear of the consequences from managers if they fall short on any budget target.

- It stifles innovation.

- It quickly becomes obsolete in a rapidly changing, globally competitive business environment.

\subsection{Targeted management control process}

Bogsnes and Boesen replaced the budget with an integrated suite of four targeted management control processes (Figure 20). The new management system delivered the capabilities of the traditional annual budget and also providing a much broader set of capabilities at lower cost and without budgeting's dysfunctional aspects. (Jorgenson, 2001)

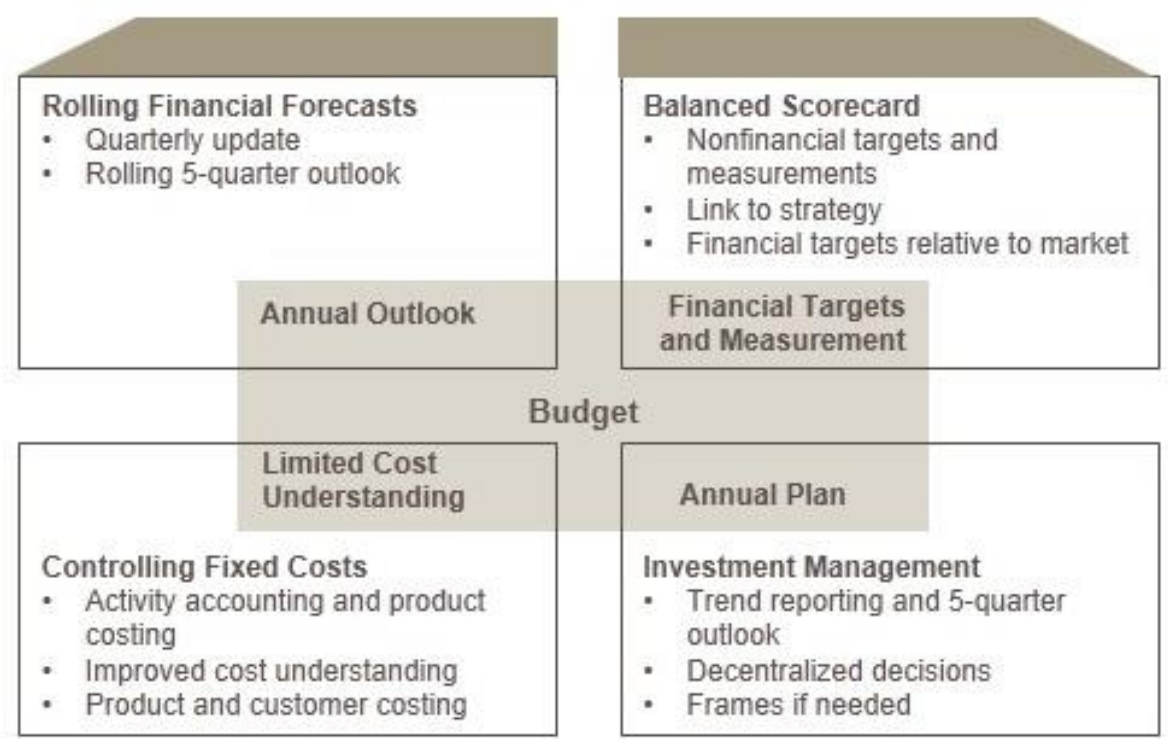

Figure 20: Integrated suite for targeted management control processes 


\subsection{Rolling Financial Forecast}

The forecasts were intended to provide an unbiased estimate of future sales and expenses and had no implications for the measurement of managerial performance. The forecasts were basically back-of-the-envelope calculations, including updates of the mail profitability drivers: volumes and prices.

\subsection{Balanced Scorecard}

BSC is used to communicate strategic objectives and measures to employees. It encouraged employees to set personal objectives that would be linked to corporate strategy. Performance of business units on the key indicators was benchmarked internally and externally. (Kaplan \& Norton, The Execution Premium, 2008)

\subsection{Controlling Fixed Costs}

In the Case Study of Borealis the budgeted line-item expense and departmental cost controls were replaced with activity-based costing (ABC), a cost management tool. The ABC model traced and accumulated line-item operating expenses into process costs and then to product and customer costs. ABC provided a common language for describing costs and for benchmarking process costs across plants and with other companies.

\subsection{Investment Management}

Kaplan refers to the model of Borealis. They eliminated centralized capital budgets and gave decision making and control to the managers and employees who 
were closest to the marketplace and customers. They segregated investment project approval by size of project. Then they tracked the cost of these small investments as a component of the twelve-month moving average of ABC. Medium-sized investments had to exceed a hurdle rate, and the executive board approved centrally the largest investment projects.

\subsection{Linking the strategy plan to a resource capacity plan and operating budget}

A comprehensive framework integrates strategic planning with resource allocation, financial forecasting, and ultimately, a dynamic budgeting process. The framework's key innovation is a time-driven activity-based cost (TDABC) model to link strategic planning to operational and capital budgeting. The framework consists of five following five steps. The basis for the model is Time-driven Activity-based costing by R.S. Kaplan and S.R. Anderson. (Anderson \& Kaplan, 2007)

\subsection{Step 1: Use driver-based revenue planning to obtain sales forecasts}

Companies need updated forecasts for several purposes. Public companies want to avoid unfavorable surprises with their investing and analyst communities. An unhappy surprise leads to loss of confidence in senior executive boards. So Kaplan stated, at a minimum, companies should continually reforecast their results to keep market expectations in line with the most likely reported financial performance.

Valid forecasts are vital for short-term financial planning. Changes in sales and expenses affect the receipt and disbursement of cash. The treasury office needs accurate forecasts of near- and intermediate-term cash receipts and expenditures. 
The quarterly rolling forecast update is not a budget done four times a year. Managers do not have to forecast line-item expenses. They can drive costs and expense forecasts directly from detailed revenue forecast.

Forecasting revenues remains a difficult process, much more complex than forecasting costs. Several companies get excellent results from an approach called driver-based planning, in which managers build a structural model, typically using extensive nonfinancial data, to predict sales.

To produce a driver-based revenue model, each company must develop its own analytic capabilities. The company develops its sales forecast from the following six key drivers:

1. New product performance

2. Advertising performance

3. Sales promotion

4. Price performance

5. Sampling performance

6. Distribution

While the process described above works well for a moving consumer goods company, a company in a different industry will have a completely different revenue model, a different supply chain, and different causal and macroeconomic factors that influence customer's purchasing decisions. Thus, driver-based revenue planning is far from trivial.

Kaplan recommends that managers drive the cost and expense estimates directly from the sales forecast. Once a sales and production forecast are produced, they can enter the forecast into a time-driven activity-based (TDABC) model that analytically 
forecasts the supply, and hence the costs, of internal resources that will provide the capacity to deliver on the sales and production forecasts.

In summary, the first step in the planning operations stage concludes with managers producing a high-level sales forecast for upcoming periods. This forecast drives the operating plan in the next steps.

2.1.4.2.2.2 Step 2: Translation of sales forecast into sales and operating plans

The next step is to translate the aggregate sales forecast into a more detailed expected operating plan for its next period of operations.

A detailed operating plan provides the essential input into a resource capacity planning model. An ERP-equipped (enterprise resource planning) company can use a baseline of recent experience from which to project into the future. To reflect the inherent uncertainly in forecasting a detailed ordering, production, and delivery schedule, managers should embrace scenario planning by developing optimistic, most likely, and pessimistic.

\subsection{TDABC Model for Forecasting Resources Capacity}

This step is the key innovation in linking a strategic plan to an operating plan. It requires that a company has a time-driven activity-based costing model in operation. TDABC assigns costs to products, services and customers based on two fundamental parameters:

First, the cost of supplying resources capacity in each operating department and process, measured as the costs of resources supplied to the department divided by the 
practical capacity (measured typically by the time available for productive work each period).

Second: the capacity (time) required from each department or process to handle the product or customer transaction.

Managers realize a major additional benefit of the company's TDABC model in form of the ability to quickly forecast and budget the needed supply of resource capacity.

Assuming that a TDABC model exists, the planning group modifies the model to reflect process improvements expected to occur in the forecasted period.

This step links the quality and process improvement activities to the planning and budgeting process.

Kaplan stated that in this way, the company's continuous improvement activities become embedded in the budgeting process. After the model's resource consumption estimates have been adjusted for the forecast process improvements, the planners enter the detailed sales and operating plan for the forecasting period into the model. By feeding forecast sales and operations data into the TDABC model, planners transform $\mathrm{ABC}$ from a snapshot-taking exercise to a management tool for influencing future costs and profitability.

Kaplan provides an example from TFS that shows how the TDABC model has enabled the company to translate its sales and operating plan into forecast demand for capacity (time) for all its personnel and computing resources. 
Time Utilization (hours)

\begin{tabular}{|c|c|c|c|c|c|}
\hline Resource Category & $\begin{array}{l}\text { Stock } \\
\text { trading }\end{array}$ & $\begin{array}{l}\text { Mutual fund } \\
\text { trading }\end{array}$ & $\begin{array}{l}\text { Investment } \\
\text { management }\end{array}$ & $\begin{array}{l}\text { Financial } \\
\text { planning }\end{array}$ & $\begin{array}{l}\text { Total } \\
\text { hours }\end{array}$ \\
\hline Brokers & $24,702^{*}$ & 4,593 & & & 29,295 \\
\hline Account managers & & & 793 & & 793 \\
\hline Financial planners & & & & 1,500 & 1,500 \\
\hline Principals & 2,391 & 451 & 187 & 90 & 3,119 \\
\hline Customer service representatives & 4,086 & 1,007 & 82 & 107 & 5,282 \\
\hline Peak MIPS utilized & 420,000 & 56,200 & 28,800 & 11,500 & 516,500 \\
\hline Off-peak MIPS utilized & 89,500 & 198,000 & 26,000 & 12,200 & 325,700 \\
\hline \multicolumn{6}{|c|}{$\begin{aligned}{ }^{*} \text { Total hours of broker usage for stock trading }= & 5 \text { minutes } \times \text { (\# transactions on existing accounts) }+ \\
& 60 \times \text { (\# accounts opened) }+20 \times \text { (\# meetings with existing } \\
& \text { customers) } \\
= & {[5 \times 275,000+60 \times 595+20 \times 3,570] / 60=24,702 \text { hours } }\end{aligned}$} \\
\hline
\end{tabular}

Table 3: Example of TDABC - step 1

In the next step (Table 3) the process continues by dividing the total demand for capacity of each resource by the quantity of capacity supplied by each unit of the resource each month.

\begin{tabular}{lrrrrrr}
\hline Resource Category & $\begin{array}{c}\text { Total } \\
\text { hours }\end{array}$ & $\begin{array}{l}\text { Available } \\
\text { hours/month } \\
\text { per resource unit }\end{array}$ & $\begin{array}{c}\text { Resource } \\
\text { units } \\
\text { required }\end{array}$ & $\begin{array}{c}\text { Resource } \\
\text { units } \\
\text { supplied }\end{array}$ & $\begin{array}{c}\text { Capacity } \\
\text { utilization }\end{array}$ \\
\hline Brokers & 29,295 & 130 & 225.3 & 230 & $98 \%$ \\
\hline Account managers & 793 & 130 & 6.1 & 7 & $87 \%$ \\
\hline Financial planners & 1,500 & 130 & 11.5 & 12 & $96 \%$ \\
\hline Principals & 3,119 & 130 & 24.0 & 25 & $96 \%$ \\
\hline $\begin{array}{l}\text { Customer service } \\
\text { representatives }\end{array}$ & 5,282 & 140 & 37.7 & 40 & $94 \%$ \\
\hline Peak MIPS utilized & 516,500 & 8.800 & 58.7 & 60 & $98 \%$ \\
\hline
\end{tabular}

Table 4: Example of TDABC - step 2

In this way, the TDABC model forecasts the quantity of resource units required to implement a future period's operating plan. "Resource Units required" in the column represent the resources demanded by the operating plan. In effect, it is the "bill" that the company must pay to deliver on its sales plan.

The calculations in the last two figures use a single-point forecast of the operating plan, but the company's planners should explore a variety of possibilities, not 
just a single forecast, to give them a sense of the range of resources required to meet a likely range of outcomes.

In general, companies should supply somewhat more capacity than the forecast by the deterministic TDABC model. To avoid queuing and delays, some buffer amount of resource capacity may be desirable.

The planning group translates each quarter's forecast into a detailed sales and operating plan, update the TDABC model for expected efficiency improvements in that quarter, and run the structural TDABC model to predict resource demand for that quarter.

In this way, the company gets an advanced look at where resource shortfalls may occur (personnel) and can also start the capital acquisition process to ensure adequate levels of physical capacity (space, servers, bandwidth, and production and distribution equipment).

This is the process by which almost all organizational costs became, as economists say, "variable in the long run". The incentives seem to be aligned for managers to generate unbiased revenue forecasts in this process so that they can make good decisions about the quantity of resource capacities to supply into future period.

In summary, a company, in step 3, uses projected sales and operating plans for the upcoming period to forecast the demand for time from employees and the demand of time and space from tangible resources, such as property, plant, and equipment. The resource demand model comes from updating the historical TDABC model for known and forecast process improvements so that the resource forecast incorporates the most contemporary thinking about future sales, operations and process efficiencies. Company planners then run their detailed sales and operating plan through the TDABC model to predict and adjust the level of supplied resources for future periods. 


\subsection{Develop the forecast of OPEX and CAPEX}

Kaplan refers to the estimated financial spending in a future period as the budget for that period, using the word budget to describe an estimate of future expenses rather than its connotation as a fixed performance target.

The result is a budget that has been derived quickly and analytically from the sales and operating plan, rather than imposed by fiat or through power negotiations. The process described here is exactly analogous to material resource planning (MRP) introduced to manufacturing companies in the 1980s. The resource capacity planning process extends the MRP model to forecast all resource capacity demand. It explodes the detailed sales and operating plans into the total demand for all resources. The spending to supply employees and to operate equipment and facilities is generally classified as OPEX and to acquire space to support growth in future operations as CAPEX.

\begin{tabular}{lrrr} 
& $\begin{array}{c}\text { Resource } \\
\text { units supplied }\end{array}$ & $\begin{array}{c}\text { Monthly resource } \\
\text { cost per unit }\end{array}$ & $\begin{array}{c}\text { Total monthly } \\
\text { resource cost (000) }\end{array}$ \\
\hline Brokers & 230 & $\$ 6.800$ & $\$ 1.561$ \\
Account managers & 7 & 9.000 & 63 \\
Financial planners & 12 & 8.400 & 106 \\
Principals & 25 & 12.200 & 323 \\
Customer service representatives & 40 & 4.000 & 168 \\
Servers & 60 & 3.200 & 190
\end{tabular}

Table 5: Example of TDABC - step 3

The company needs one additional set of estimates: the forecasts of the level of discretionary spending in items such as research, development, advertising, promotion, training, and strategic initiatives (STRATEX). The forecast spending on these discretionary items does not bear a tight causal relationship with sales and operating levels, and therefore it requires a parallel calculation along with the quarterly update of 
revenues. The spending on such discretionary items remains a judgment call by experienced executives.

\subsection{Step 5: calculate profitability}

The TDABC model supplies, essentially for free, the detailed profit-and-loss statement (P\&L) for each product (see Table 6), customer, and region. By going back to the detailed sales and operating plan, the model automatically attributes the supply and cost of each resource type to the transaction, product, or customer that triggered the demand.

\begin{tabular}{|c|c|c|c|c|c|c|c|}
\hline & $\begin{array}{l}\text { Stock } \\
\text { trading }\end{array}$ & $\begin{array}{l}\text { Mutual fund } \\
\text { trading }\end{array}$ & $\begin{array}{c}\text { Account } \\
\text { management }\end{array}$ & $\begin{array}{l}\text { Financial } \\
\text { planning }\end{array}$ & \multirow[t]{2}{*}{$\begin{array}{l}\text { Total } \\
\text { used }\end{array}$} & $\begin{array}{l}\text { Unused } \\
\text { capacity }\end{array}$ & \multirow[t]{2}{*}{$\begin{array}{c}\text { Total } \\
\text { supplied }\end{array}$} \\
\hline Average price per transaction & $\$ 13.25$ & $\$ 41.45$ & & & & & \\
\hline Sales & $\$ 3,644$ & $\$ 2,031$ & $\$ 113$ & $\$ 169$ & $\$ 5,956$ & & $\$ 5,956$ \\
\hline Brokers & 1,290 & 240 & & & 1,529 & 32 & 1,561 \\
\hline Account managers & & & 55 & & 55 & 8 & 63 \\
\hline Financial planners & & & & 102 & 102 & 4 & 106 \\
\hline Principals & 238 & 45 & 19 & 9 & 310 & 13 & 323 \\
\hline Customer service representatives & 122 & 30 & 2 & 3 & 158 & 10 & 168 \\
\hline Computer server expenses & 128 & 39 & 11 & 5 & 184 & 6 & 190 \\
\hline Total costs & 1,778 & 354 & 87 & 119 & 2,338 & 73 & 2,411 \\
\hline Margin & 1,866 & 1,677 & 26 & 50 & 3,618 & (73) & 3,545 \\
\hline Margin \% & $51 \%$ & $83 \%$ & $23 \%$ & $30 \%$ & $61 \%$ & $-1 \%$ & $60 \%$ \\
\hline $\begin{array}{l}\text { S, G \& A } \\
\text { (unallocated corporate expenses) }\end{array}$ & & & & & & & 1,300 \\
\hline Operating income & & & & & & & 2,245 \\
\hline Operating margin & & & & & & & $38 \%$ \\
\hline
\end{tabular}

Table 6: Example of TDABC - step 4

Summarizing Kaplan’s 5-step method starts with quarterly sales forecasts for the next several periods. In the next step, planners translate high-level sales forecasts into detailed sales and operating plans. In a third step, the detailed sales and operating plans are converted, through a time-driven activity-based cost model, into the forecast demand for capacity of the company's primary resources. In step 4, planners simply and accurately translate the authorized level of resource supply into budgeted operating and capital expenses for the upcoming periods. In step 5, the pro forma profit-and-loss 
statement, is aggregated for the business unit or company and by product, service, customer, channel, and region.

This series of logical and tightly linked steps provides a mechanism for translating high-level sales growth targets into detailed plans for authorizing resource capacity, and in step 5, estimating the near-term operating profitability, by products, customers, and regions, from the strategic plan.

\subsubsection{Step 5: Monitor and Learn}

In this chapter Kaplan's provides concepts how to monitor the execution and the linking of the strategy and operations.

The enterprise needs to continually monitor and adjust its performance to achieve strategic objectives. Managers' aim is to review the strategy and to adjust or transform it as needed.

In the language of total quality management, the various management meetings are the check and act portions (from PDCA cycle) of the strategy implementation process. Companies need to clearly separate the agendas and participants at their management meetings. (see Table 7) (Kaplan \& Norton, The Execution Premium, 2008) 


\begin{tabular}{|c|c|c|c|}
\hline $\begin{array}{l}\text { Feedback } \\
\text { and Learning } \\
\text { Process }\end{array}$ & Objective & Barriers & $\begin{array}{c}\text { Representative } \\
\text { Activities }\end{array}$ \\
\hline $\begin{array}{l}\text { 1. Operational } \\
\text { Review Meetings } \\
\text { Are our operations } \\
\text { in control? }\end{array}$ & $\begin{array}{l}\text { To monitor and manage } \\
\text { short-term financial and } \\
\text { operational performance }\end{array}$ & $\begin{array}{l}\text { KPIs and dashboards } \\
\text { that managers review } \\
\text { not central to the strategy }\end{array}$ & $\begin{array}{l}\text { - } \text { Driver models } \\
\text { - } \text { Variance analysis } \\
\text { Review of KPI } \\
\text { dashboards } \\
\text { - } \text { Team problem solving } \\
\text { - } \text { Follow-up program }\end{array}$ \\
\hline $\begin{array}{l}\text { 2. Strategy Review } \\
\text { Meetings } \\
\text { Are we executing our } \\
\text { strategy well? }\end{array}$ & $\begin{array}{l}\text { To monitor and manage } \\
\text { the strategic initiatives } \\
\text { and the Balanced } \\
\text { Scorecard }\end{array}$ & $\begin{array}{l}\text { - Inadequate time at } \\
\text { management meetings for } \\
\text { discussions about strategy } \\
\text { implementation } \\
\text { - Strategic., cross-business } \\
\text { initiatives are not monitored } \\
\text { or managed for results }\end{array}$ & $\begin{array}{l}\text { - Theme monitoring } \\
\text { - Initiatives portfolio } \\
\text { monitoring } \\
\text { - Theme teams } \\
\text { - Agenda management }\end{array}$ \\
\hline $\begin{array}{l}\text { 3. Strategy Testing } \\
\text { and Adapting } \\
\text { Meetings } \\
\text { Is our strategy } \\
\text { working? }\end{array}$ & $\begin{array}{l}\text { To periodically assess } \\
\text { whether the results } \\
\text { hypothesized in cause- } \\
\text { effect diagrams are } \\
\text { occurring as anticipated }\end{array}$ & $\begin{array}{l}\text { Data not available to review } \\
\text { and test the hypotheses } \\
\text { underlying the strategy } \\
\text { - Inadequate capability in } \\
\text { strategy analytics to test } \\
\text { the strategy } \\
\text { - Employees not encouraged } \\
\text { to propose new strategic } \\
\text { options }\end{array}$ & $\begin{array}{l}\text { - Analytic studies } \\
\text { - ABC studies of product } \\
\text { and customer profitability } \\
\text { - Cause-effect testing and } \\
\text { analysis } \\
\text { - Review of emergent } \\
\text { strategies }\end{array}$ \\
\hline
\end{tabular}

Table 7: Overview of Monitor and Learn Meetings

Operational review meetings examine recent departmental, functional, and financial performance and address immediate problems that must be solved.

Strategy review meetings examine indicators and initiatives from the unit's BSC to assess the progress, barriers, and risks associated with the successful implementations of the strategy.

Strategy testing and adapting meetings discuss whether the strategy is working and whether its fundamental assumptions remain valid in light of data that have been collected on strategic measures. Details to this topic are presented in the last step six of Kaplan's management system. (Kaplan \& Norton, The Execution Premium, 2008)

\subsubsection{Operational Review Meetings}

Operational review meetings assess short-term performance and respond to problems that have arisen recently and need immediate attention. 
The frequency of these meetings should be determined by the operating cycle of the department and business and by how quickly management wants to respond to sales and operating data as well as to the myriad of other tactical issues that continually emerge.

The attendees of most operational review meetings come from a single department, function, or process. Operational meetings should be short, highly focused, and action oriented. Many companies' operational review meetings devote too much time to distributing and presenting data, best-practice organizations distribute reports in advance or make the underlying data accessible through Web-enabled information technology. The meetings should be based on valid operational data. The meetings focus on near-term operational issues and generate actions that can be taken immediately to address the problems. Operational review meetings focus on departmental and process performance and provide opportunities for feedback, problem solving, and learning. (Kaplan \& Norton, The Execution Premium, 2008)

\subsubsection{Strategy Review Meetings}

In strategy review meetings, the members of a business unit's leadership team come together to monitor and discuss the progress of the unit's strategy. The discussion focuses on whether strategy execution is on track, identifies the risks of successful strategy execution, detects where problems are occurring in the implementation, attempts to determine why the problems are occurring, takes actions to correct the cause, and assigns responsibility for achieving the targeted results. Strategy review meetings require mandatory attendance and a commitment to start and end meetings on time. 
Executive committee members should be core participants in the strategy review meetings, with people added over time who have either a comprehensive strategic perspective or in-depth knowledge of an important function.

Assigning responsibility for individual strategic themes to new committee members is an excellent way to give them legitimacy comparable to that of the traditional members, who have an existing power base. (Kaplan \& Norton, The Execution Premium, 2008)

To differentiate the focus of this body, Kaplan refers to it as the strategy council. As with operational review meetings, the strategy council's time should not be spent listening to report presentations. Strategy council members should discuss issues, solve problems, and propose action plans.

One current best practice is for the agenda to include a quick overview of the entire scorecard. In this way, the executive leadership team can identify any strategic issue requiring its immediate attention, devote some time to discussion of monthly financial performance, and spend the bulk of the time in a focused deep dive into one of the other three BSC perspectives or a single strategic theme.

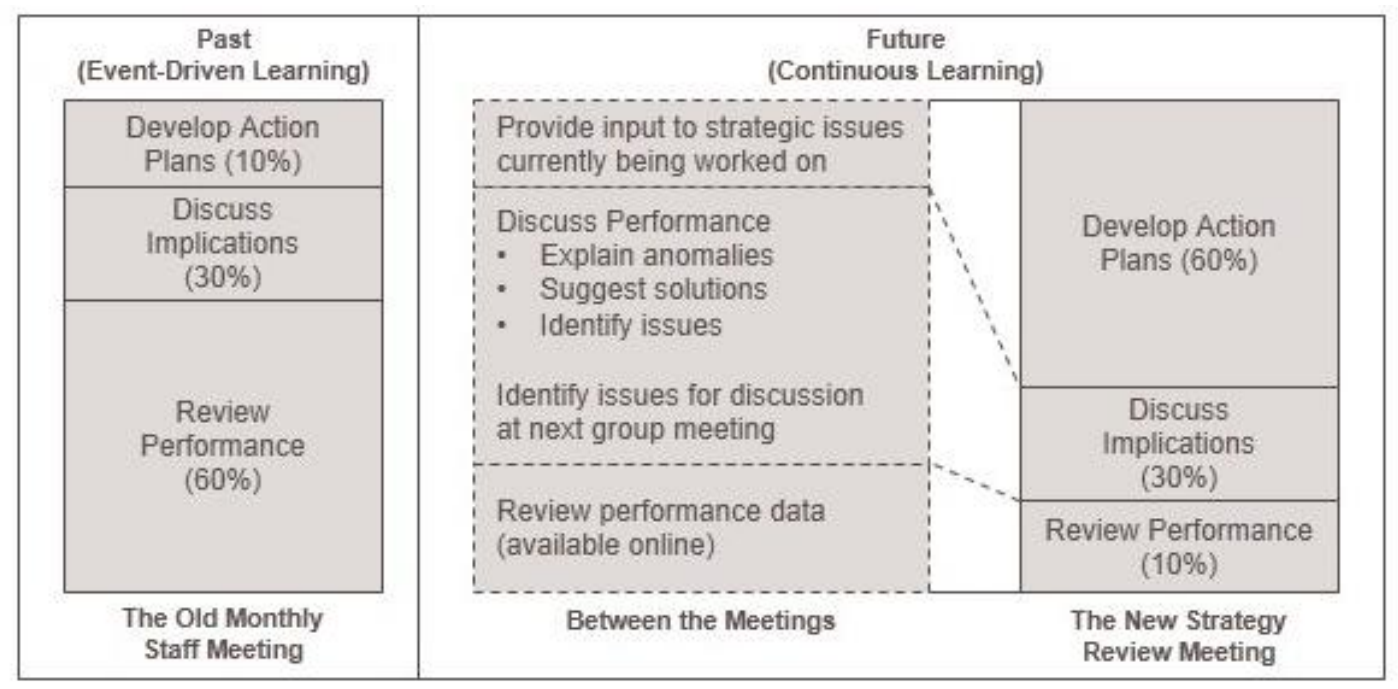

Figure 21: structure for a strategy review meeting 


\subsubsection{Step 6: Test and Adapt}

The last step of Kaplan's management system for linking strategy to operations is dedicated to the topic of testing and adapting the strategy in the context of operational execution.

A strategy map and BSC make explicit the linked hypotheses underlying an organization's strategy, but apart from a company's ability to execute its strategy, it cannot be certain that the assumptions and hypotheses underlying the strategy are valid. A principal benefit of implementing a strategy with a BSC is that company can use the scorecard data to periodically assess whether its strategic hypotheses are valid. (Kaplan \& Norton, The Execution Premium, 2008)

\subsubsection{Strategy testing and adapting meetings}

Kaplan stated that strategy testing and adapting meetings are designed for the executive team to learn about the validity of the strategy - not only its execution - and to modify and adapt the strategy over time. A well-formulated strategy map, with its accompanying BSC, represents a linked and comprehensive set of assumptions about how the strategy will create and sustain long-term shareholder value. Kaplan stated that every company should, at least annually - and perhaps as often as quarterly - conduct a separate meeting to assess the performance of its strategy and consider the consequences of recent changes in its external environment. This meeting can and should be the same meeting described in the first step of his system for developing a new strategy. The output of the strategy testing and adapting meeting can be to reaffirm the existing strategy, in which case the executive team updates targets, reprioritizes strategic initiatives, and transmit new expectations to business units and functions. The 
current strategy meeting participants must also consider changes in external conditions. The executive team needs to assess whether such changes require abandoning or modifying the strategy in significant ways.

The strategy testing and adapting meeting provides an ideal time for the executive team to consider ideas about strategy visions and initiatives that have emerged from within the organization. Companies should actively solicit and assess ideas for new strategic options so that they can benefit from the awareness of the strategy by all employees in the enterprise and their motivation to help it succeed.

\subsubsection{Operational feedback for testing the strategy}

The strategic planning department conducts a PESTEL analysis to bring together external data, which need to be updated to reflect changes that have occurred since the last strategy update meeting in political and external macroeconomic conditions. The executive team also needs detailed data on the company's current performance. Granular P\&L data give companies much more visibility into the strengths and weakness of their current performance.

Companies can enhance their strategy review process by examining the existing microeconomics of their individual products and customers, along with the statistical correlations between the assumed drivers of their strategies and the outcomes they are experiencing. (Kaplan \& Norton, The Execution Premium, 2008)

\subsubsection{TDABC models of product and customer profitability}

The ultimate test of any strategy is whether it makes more money for the company. But rather than working only with a highly aggregated income statement to 
determine whether it is making money, the company should calculate individual product, customer, segment, channel, and regional P\&L statements. Computer-based TDABC models deliver individual P\&Ls accurately and at low cost, facilitating such strategy reviews. It targets those areas where profit enhancements are most needed and are most likely to be realized. (Kaplan \& Norton, The Execution Premium, 2008)

\subsubsection{Statistical testing of operational linkages}

Measuring whether the company's value proposition and cost structure have produced profitable customer relationship is one powerful test of a strategy. Another test, complementary to the $\mathrm{ABC}$ test, is to examine statistically the linkages among improvements in the BSC metrics. The strategy map hypothesizes that improvements in learning and growth metrics should lead to improvements in process metrics, which, in turn, should lead to improvements in customer and financial metrics. With data collected from the strategy's BSC, statistical analysis can test whether a variable, assumed to have a strong positive connection to a customer or financial outcome, actually has zero or a negative correlation with these strategy outcome indicators. Such a finding would signal to the executive team that some of the assumed logic in its strategy may be invalid.

The requirements for formal statistical testing are:

- The companies had multiple observations per time period.

- The companies had disciplined processes for collecting data from each site about customer satisfaction and loyalty, process characteristics, and employee attitudes and skills. 
- Having the capability to perform the statistical analysis in a valid and credible manner

Companies that want to use their BSC data to test strategic hypotheses should have an internal group or external consultants who are well trained and experienced in designing, estimating, and testing statistical models.

\subsubsection{Emergent strategies}

Several strategy scholars emphasize the limitations of top-down strategic direction. (Mintzberg \& J. Waters, 1985). They argue that some of the best ideas for new strategies come from employees within the organization. The role of senior management is to be ever alert to innovative ideas that employees, who are close to technologies, processes, and customers, can suggest even when these suggestions originate outside the official strategy planning and review process. (Kaplan \& Norton, The Strategy-Focused Organization, 2000)

Employees who understand about the strategy are in an excellent position to see where gaps exist either in strategy implementation or in an underlying hypothesis. They may even identify where a new strategic approach might yield better performance.

\subsubsection{Back loop from operations to strategy}

Strategy maps and BSC help organizations link strategy to operations and managers to communicate the strategy in both visual and quantitative terms, however less well celebrated, is the link from operations back to strategy. Table 8 summarizes 
the three management meetings which provide the feedback from operations to strategy.

\begin{tabular}{|c|c|c|c|}
\hline & Operational Review & Strategy Review & Strategy Testing and Adapting \\
\hline $\begin{array}{l}\text { Information } \\
\text { requirements }\end{array}$ & $\begin{array}{l}\text { Dashboards for key } \\
\text { performance indicators; } \\
\text { weekly and monthly } \\
\text { financial summaries }\end{array}$ & $\begin{array}{l}\text { Strategy map and } \\
\text { Balanced Scorecard } \\
\text { reports }\end{array}$ & $\begin{array}{l}\text { Strategy map, Balanced } \\
\text { Scorecards, ABC profitability } \\
\text { reports, analytic studies of } \\
\text { strategic hypotheses, external } \\
\text { and competitive analyses, } \\
\text { emergent strategies }\end{array}$ \\
\hline Frequency & $\begin{array}{l}\text { Daily, twice weekly, } \\
\text { weekly, or monthly, } \\
\text { depending on business } \\
\text { cycle }\end{array}$ & Monthly & $\begin{array}{l}\text { Annually (perhaps quarterly for } \\
\text { fast-moving industries) }\end{array}$ \\
\hline Attendees & $\begin{array}{l}\text { Departmental and } \\
\text { functional personnel; } \\
\text { senior management for } \\
\text { financial reviews }\end{array}$ & $\begin{array}{l}\text { Senior management } \\
\text { team, strategic theme } \\
\text { owners, strategy } \\
\text { management officer }\end{array}$ & $\begin{array}{l}\text { Senior management team, } \\
\text { strategic theme owners, } \\
\text { functional and planning } \\
\text { specialists, business unit heads }\end{array}$ \\
\hline Focus & $\begin{array}{l}\text { Identify and solve } \\
\text { operational problems } \\
\text { (sales declines, late } \\
\text { deliveries, equipment } \\
\text { downtime, supplier } \\
\text { problems) }\end{array}$ & $\begin{array}{l}\text { Issues in strategy } \\
\text { implementation, } \\
\text { progress of strategic } \\
\text { initiatives }\end{array}$ & $\begin{array}{l}\text { Test and adapt strategy based } \\
\text { on causal analytics, product-line } \\
\text { and channel profitability. } \\
\text { changing external environment, } \\
\text { emergent strategies, and new } \\
\text { technology developments }\end{array}$ \\
\hline Goal & $\begin{array}{l}\text { Respond to short-term } \\
\text { problems and promote } \\
\text { continuous improvements }\end{array}$ & $\begin{array}{l}\text { Fine-tune strategy; } \\
\text { make midcourse } \\
\text { adaptations }\end{array}$ & $\begin{array}{l}\text { Incrementally improve or } \\
\text { transform strategy; establish } \\
\text { strategic and operational plans; } \\
\text { set strategic targets; authorize } \\
\text { spending for strategic initiatives } \\
\text { and other major discretionary } \\
\text { expenditures }\end{array}$ \\
\hline
\end{tabular}

Table 8: Overview of Reviews, Testing and Adaption

\subsubsection{The office of strategy management}

\subsubsection{The need of the OSM}

The six management processes have many moving parts and interrelationships, and it requires simultaneous coordination among all line and staff units (see Figure 22). On top the organizations face a complex task to implement such a complex, interrelated system of mature and newly introduced management processes. 


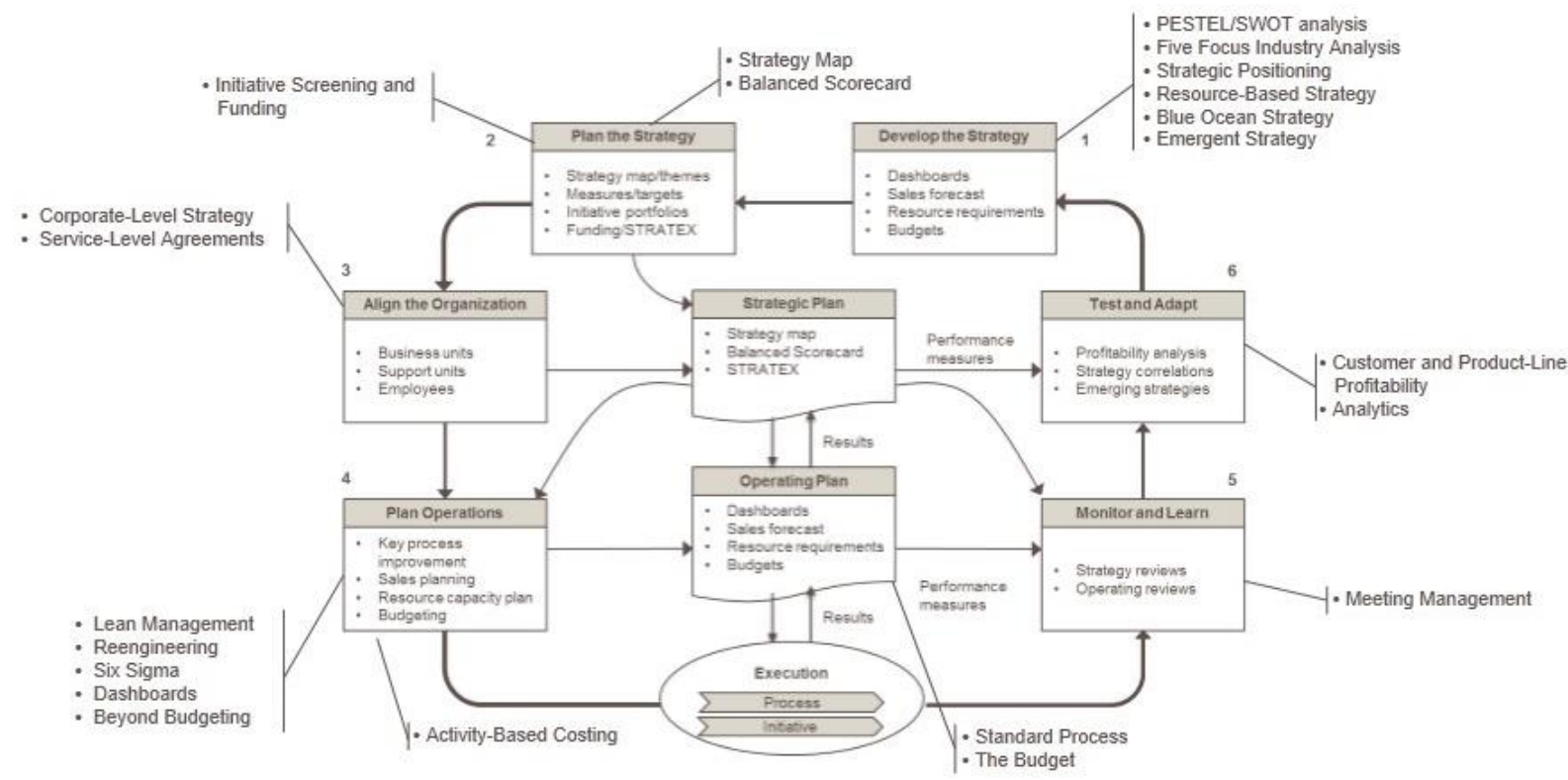

Figure 22: overview of tasks in the management system

For that reason Kaplan and his team identified the need for a new organizational function, which they call the office of strategy management (OSM), to be the process owner of the strategy execution system, because few organizations identify an individual or department to run the multiple linked processes of the strategy execution system.

\subsubsection{Roles of the OSM}

The new office of strategy management plays three generic rolls. First, the OSM, as architect, designs the new strategy and operational management processes. Second, the OSM is the owner of many of the key processes in the management system.

Third, the OSM serves as an integrator to align all diverse processes with the strategy. Figure 23 gives an overview and shows the relations of these three roles. (Kaplan \& Norton, The Execution Premium, 2008) 


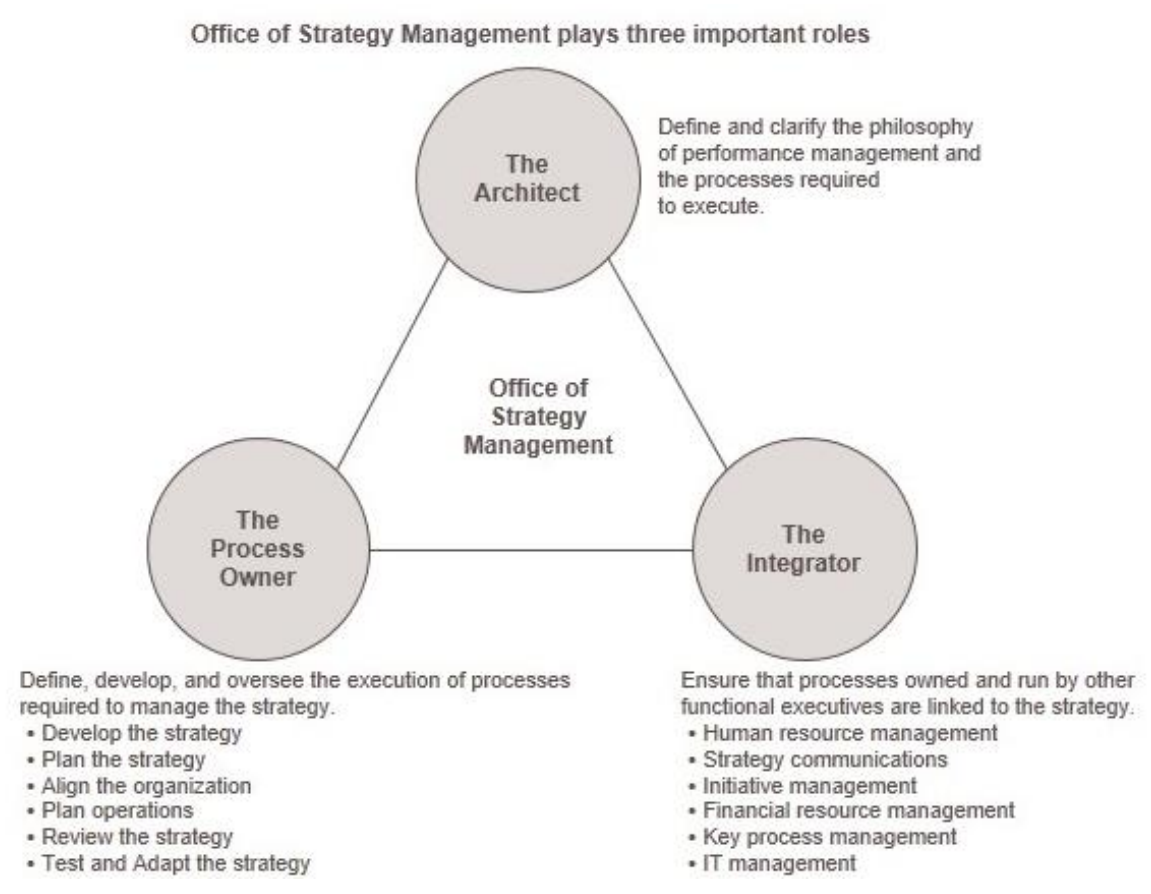

Figure 23: Roles of the OSM

\subsection{The OSM as Architect}

The OSM is the designer of the framework and processes for a single, integrated, closed-loop strategy planning and operational execution system its tasks include introducing the missing strategy execution processes and bringing order to an otherwise incomplete and fragmented collection of management processes. The OSM creates the design for the sequence and linkage of strategy execution processes shown in Figure 24. (Kaplan \& Norton, The Office of Strategy Management, 2005) 


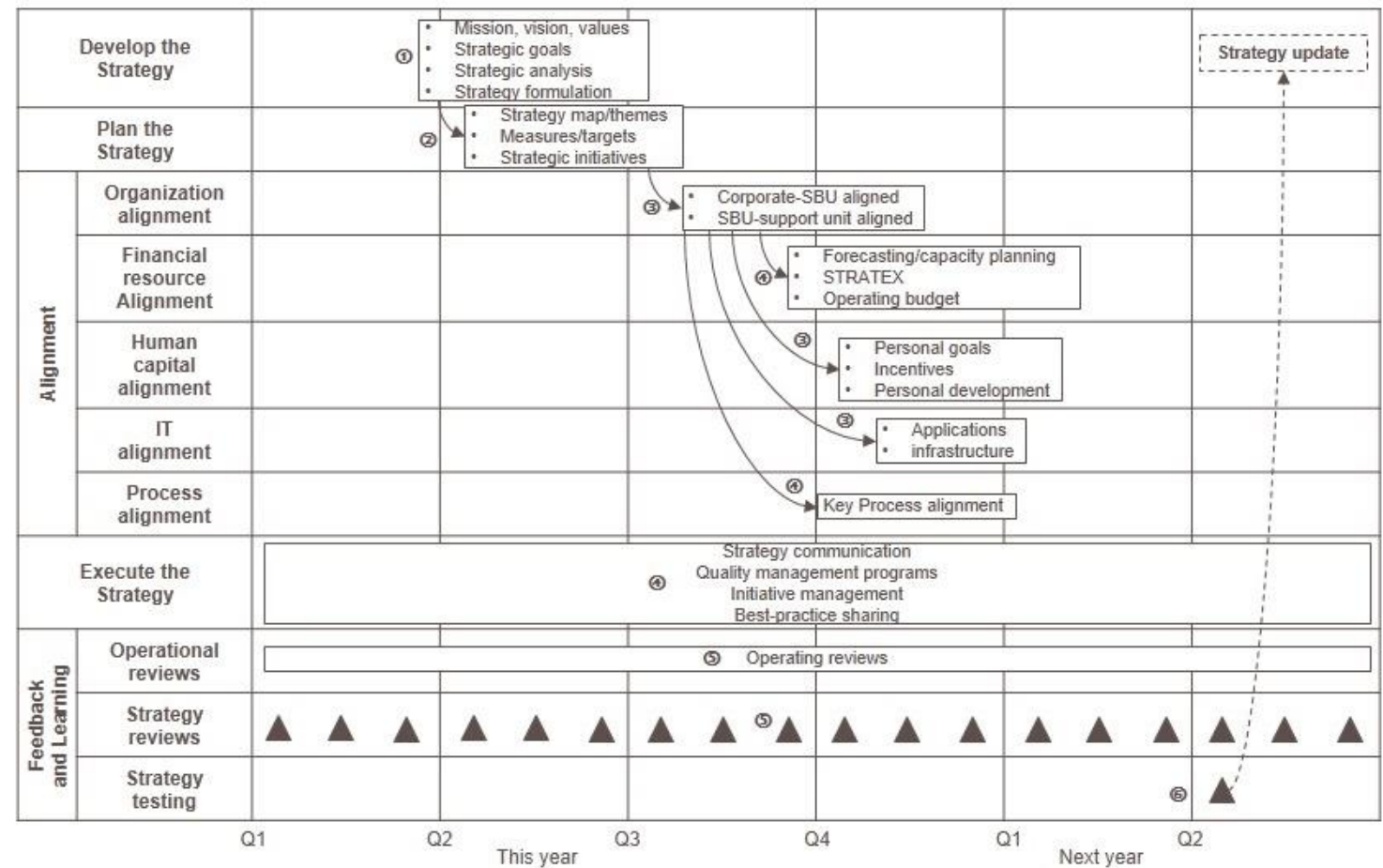

Figure 24: Sequence of strategy execution

In parallel with sequencing these annual processes, the OSM oversees several continual control and learning processes: communicating strategy, reviewing operations and strategy, managing strategic initiatives, and sharing best practices. The OSM monitors all these components to ensure that they are in place, introducing any missing ones and establishing the links that must exist between them.

\subsection{The OSM as Process Owner}

On an ongoing basis, the OSM should have primary ownership of the following strategy execution processes. Kaplan describes the Roles with the following main thesis.

Developing the strategy - Encourage an expansion of the strategic planning department into a more comprehensive office of strategy management that has responsibility for facilitating both strategy development and its execution. 
Planning the Strategy - By owning the scorecard process, the OSM ensures that any changes made at the annual strategy planning meeting are translated into the company's strategy map and BSC. The OSM coaches the executive team in selecting performance targets on the scorecard measures and identifying the strategic initiatives, and then standardizes the terminology and measurement definition, and selects and manages the scorecard reporting system, and monitors the integrity of the scorecard data. The OSM serves as the central scorecard resource, consulting with units on their scorecard development and conducting training and education on building strategy maps and scorecard.

Aligning the Organization - The OSM oversees the processes to cascade strategies and scorecards vertically and horizontally throughout the organization.

Reviewing the Strategy: Managing the new strategy review meeting is a core function of the OSM.

Adapting the Strategy - An analysis which strategy testing and adapting meeting requires, is that the sophisticated analytics to statically estimate and test strategic linkages. The OSM is a natural hole for building a corporate capability to analyze data coming from BSC.

\subsection{The OSM as Integrator}

The OSM ensures that near-term planning and budgeting are aligned with strategic priorities and the strategy is communicated and internalized by the workforce. In detail the following fields are in scope for the role as an integrator:

Linking Strategy to Financial Resource Planning and Budgeting - The OSM integrates with finance to ensure that business unit profit plans, resource capacity planning, and performance targets are aligned with strategic objectives. 
Aligning Plans and Resources of Important Functional Support

Departments - The OSM plays a consulting and integrating role with these functional departments to help them align their strategies and plans with enterprise and business unit strategy.

Communicating the Strategy - If the communication task is assigned to an existing communication department, the OSM plays an editorial role and if not, becomes the process owner for communicating both strategy and the scorecard to employees. The OSM coordinates with HR department to ensure that education about the scorecard and employees' role in delivering performance is included in employee training programs.

Managing Strategic Initiatives - When the organization uses theme owners and theme teams to manage selection and management of strategic initiatives, the OSM monitors the process, soliciting information about initiative status and performance and reporting this information to the executive team, when the organization doesn't use them, the OSM is the default mechanism for running the team process to select and rationalize strategic initiatives.

Linking Strategy to Key Operating processes - The OSM works with theme teams, local line management, and the quality management department to see that necessary resources and organizational support have been provided to improve the performance of the strategic processes.

Sharing Best Practices - The OSM must take the lead in transferring ideas and best practices throughout the organization. (Kaplan \& Norton, The Execution Premium, 2008) 


\subsection{Balanced Score Card: Translating strategy into action}

Since the reference Balanced Score Card is a basis for the assumptions of Kaplan's Execution Premium, the main issues of the reference will be described in the following chapter for a better understanding, even though it is not a focus topic of this dissertation

The Balanced Scorecard relies on four perspectives. It is a management tool for planning strategies and link them to operational measurements.

\subsubsection{Perspective One: "Financial Perspective"}

Kaplan stated that building a balanced scorecard should encourage business units to link their financial objectives to corporate strategy or wise worse. The financial perspective can be defined within the following measures:

"Revenue growth and mix" - measured by sales growth rates of the company and market share for target regions.

"New products" and "new applications" - measured by the percentage of revenue from new products and services introduced in a special time period versus the percentage of existing products and services. New applications is a measurement of the number of evaluating existing products to new designs.

"New customers and markets" - measured by the percentage of revenue with new customers in a defined time period or won market share within a new defined market segment.

"New relationships" - measured by the amount of revenue from cooperative relationships with partner companies. 
"New pricing strategy" - measured by the part of revenue earned by changing the pricing strategy e.g. cut discounts.

“Increased revenue productivity" - measured by two different scenarios: first for companies or business units in the growth stage the measurement should be the revenue enhancement, companies with stabile business should measure cost reductions.

"Reduced operating expenses" - measured by the amount of operating expenses per product, service or process.

"Cash-to-cash cycle" - measured by the ratio between getting revenues paid by customers and paying vendors.

(Kaplan \& Norton, The Balanced Scorecard, 1996)

\subsubsection{Perspective Two: "Customer Perspective"}

The second perspective Kaplan describes is the customer perspective. This perspective describes the link of strategic objectives to customer and market values. As organizations invest in acquiring these new capabilities, their success (or failure) cannot be motivated or measured in the short run by the traditional financial accounting model. (Kaplan \& Norton, The Balanced Scorecard, 1996). Or otherwise customer needs in form of product and service requirements are a long-run success-factor for the company.

Typical measurements Kaplan pointed out in this area are

- market share

- customer retention

- customer acquisition

- customer satisfaction

- customer profitability. 


\subsubsection{Perspective Three: "Internal Business-Process Perspective"}

In this chapter Kaplan focuses on internal operations processes and how companies design their process for producing products or serving services. Also business processes like sales and administration processes need to be measured. Typical measures are:

- the capability of the production line

- time to market for the development of products or services

- process times for acquisitions.

\subsubsection{Perspective Four: "Learning and Growth Perspective"}

The fourth perspective is dedicated to the HR-sector. Without optimal skilled workers all other strategy goals cannot be achieved. Kaplan stated that beyond investments into new products, production lines, research and development, the investment in employee capabilities, IT systems and infrastructure and in an environment of motivation is the basis for successful companies and therefor an own strategic perspective. Typical measures named by Kaplan are:

- assessing worker satisfaction

- productivity levels

- training and skill levels

- level of performance-improvement

- level of individual performance goals reached 


\subsection{5 "Feedback and the Strategic Learning Process"}

Kaplan and his team stated that the setting of a "shared strategic framework" need to be performed. Meaning that companies need to develop systems encouraging organization-wide strategic learning and feedback loops and move away from hierarchical management systems. Employees deserve to know the strategy and the role they play. (Kaplan \& Norton, The Balanced Scorecard, 1996)

\subsection{The strategy-focused organization}

The reference strategy-focused organization is no direct focus topic of the dissertation, but a main basis for the assumptions of Kaplan's Execution Premium. For that reason the main issues out of the reference will be described.

As described in chapter 2.2. the balanced scorecard is a very useful instrument to plan strategy and make it measureable. Kaplan stated in his book the strategy-focused organization that beyond using the tool the need for a change in the organizational structure is needed to succeed the operationalization of strategies. These changes to a strategy focused organization are described with respect of using the balanced scorecard within a framework of five principals as shown in the below figure. 


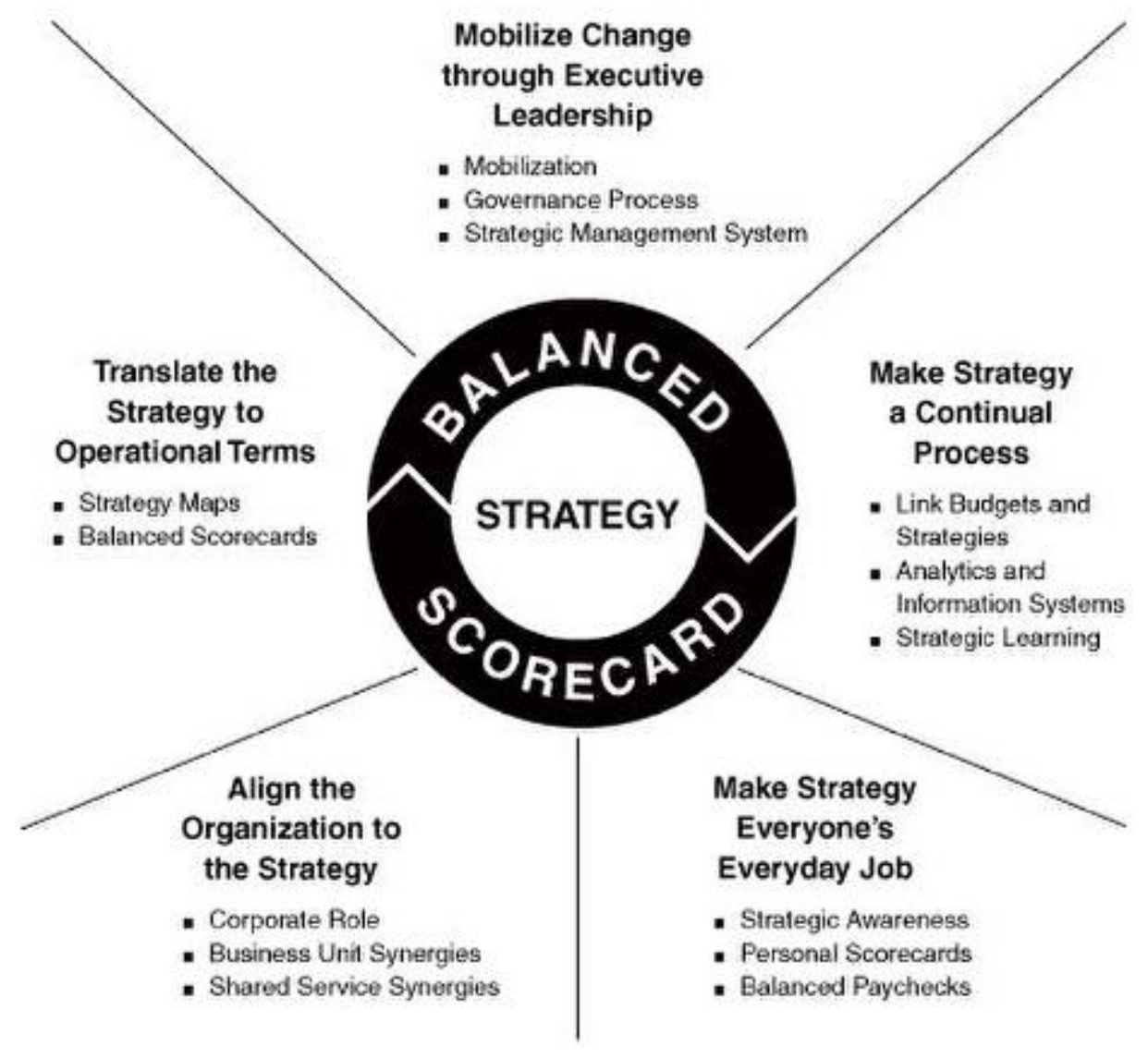

Figure 25: Five principles of strategy-focused organization

\subsubsection{Principle 1: "Translate the Strategy to Operational Terms"}

The Balanced Scorecard provides a framework to describe and communicate strategy in a consistent and insightful way. (Kaplan \& Norton, The Strategy-Focused Organization, 2000). This definitions are the basis for company-leaders to break down strategy goals to operational goals. Kaplan provides the tool of strategy maps for the transfer of strategic goals to tangible and non-tangible assets. Tangible assets are much easier to measure than intangible assets like knowledge or process improvement. The value of intangible assets mostly rise by bundling them with other assets and streamline them to an overall strategy. 


\subsubsection{Principle 2: "Align the Organization to the Strategy"}

Synergy is the overarching goal of organization design. For organizational performance to become more than the sum of its parts, individual strategies must be linked and integrated. (Kaplan \& Norton, The Strategy-Focused Organization, 2000)

Organizations based on functional departments are a major barrier for strategy implementation and with the transformation to a strategy focused organization this barrier needs to be broken.

Kaplan states that the main issue within this principle is to break down the functional structure (hierarchy, reporting, goal-setting) and replace them with strategic themes and priorities. He defines two possible ways performing this break down. First "The strategic partner model" - where business and shared units work under partnership conditions and develop corporate balanced score cards. Second "The business-in-abusiness model" - business units don't develop and execute their own balanced score part but are part of other scorecard goals coordinated by shared service units. (Kaplan \& Norton, The Strategy-Focused Organization, 2000)

\subsubsection{Principle 3: "Make Strategy everyone's Everyday Job"}

Strategy-Focused Organizations understand well the importance of engaging and aligning all of their employees to the strategy. (Kaplan \& Norton, The StrategyFocused Organization, 2000). Kaplan provides three major steps for getting strategy everyone's everyday job.

1. Communication and education: Workers must understand and learn about the strategy 
2. Developing personal and team objectives: Breaking down the strategy goals to personal goals strength the will to execute them, especially connecting the goals with

3. Incentive and reward systems.

\subsubsection{Principle 4: "Make Strategy a Continual Process"}

For most organizations, the management process is built around the budget and operating plan. The successful balanced scorecard companies introduce a process to manage strategy. (Kaplan \& Norton, The Strategy-Focused Organization, 2000) Kaplan refers to a "double-loop process" - one that integrates the management of tactics and the management of strategy into a seamless and continual process. Three main steps are described by Kaplan:

1. Link strategy to the budgeting process with STRATEX

2. Management meetings for strategy review

3. Learning and adapting the strategy.

This chapter is a first step and the bases for the execution premium.

\subsubsection{Principle 5: "Mobilize Change through Executive Leadership"}

The first four principles focus on the balanced scorecard tool, the needed framework and the supporting processes. (Kaplan \& Norton, The Strategy-Focused Organization, 2000) Kaplan is very clear about the topic that there is more than tools and processes getting to a strategy focused organization: Strategy requires change from 
every part of the organization. (Kaplan \& Norton, The Strategy-Focused Organization, 2000). He mentions three major steps.

1. Mobilization

2. governance

3. Strategy management system 


\section{EXPERIMENT}

The Experiment chapter shows the execution of the theoretical concepts from execution premium in a practical business case. It contains a detail description how and with which methods and approaches the several steps are performed in the experiment. The experiment is a real life case in the energy industry executing the setup and execution of a new sales strategy with respect to the changes in the energy market in Germany. The experiment was performed before the development of the ISOL-M. Therefore it was the basis for realizing the concepts of Kaplan's premium execution in a real world case.

In the upcoming chapter 4 the GAP's by doing the experiment are described and in chapter 5 a best-practice approach filling these GAP's is provided.

\subsection{Environment for the experiment}

The German energy market was government controlled till 2005. An EU novella from 2003 brought the end of the monopolism in the energy market (energy, gas) and therefor an extreme change for the energy market need to be done. The change from a government controlled monopolist to a free-market company with the awareness of customers and competitors.

With this change the need for strategic management came up very quickly. The management of these energy companies need to set up very quickly a managerial system for defining and executing all the core fields a free-market company needs to 
exist. Questions like: What is our vision, what is our USP, how do we earn money and other essential question come up.

Therefore the board launches a 20 month long initiative called "strategic excellence 12 " to setup a framework for strategic realization in the sales department which was the driver for the overall strategic roadmap of the company.

\subsection{Step 1 and 2: Develop and plan the strategy}

Within the strategic management the development and the planning of the strategy was performed. To define visions and missions top management workshops have been done and from this point the overall strategy was development with respect to the results of a PESTEL and SWOT analysis.

In the next process step possible strategy approaches for the sales department are collected and formulated. In a second step a strategy map with respect to the four perspectives of the balanced score card was developed.

In the third step the breakdown of the overall map to department maps was performed and existing and new initiatives where defined. The last process was to calculate the strategic budget (STRATEX) for the initiatives and evaluate them in form of a cost-benefit analysis, which was the basis for the selection of the to-be operated initiatives.

\subsection{Step 3: Align the organization}

The next step was to prepare the organization. A first approach was to segment the sales department into three levels. 
Level 1 - Strategic Management, which is dedicated to step 1 "develop the strategy" and step 2 "plan the strategy" from Kaplan’s system.

This level is linked to the organizational level of the CMO (Chief of Marketing and Sales) and the new generated Office of Strategy Management (OSM).

Level 2 - Tactical Management, dedicated to step 3 to 6 in Kaplan's system, was linked to the mid-management level (department leaders)

Level 3 - Operational Management, dedicated to execute the initiatives was linked to the operational units, controlled by the team leaders.

Above that every project for initiates gets a project organization with project lead, project members and line managers dedicated to every project.

\subsection{Step 4-6: Plan Operations, Execution, Monitor and Learn, Test and Adapt}

In the tactical management process the following steps of Kaplan's system were done:

- Plan Operations

- Control and learn

- Test and adapt

The output of step 1 was a tactical plan in form of revenue- and budget plans (overall, department driven), resource- and capacity plans connected to a RASIC model for the alignment of the organization. 
For step 2 and 3 a setting of several meetings on different levels with different tools for collecting and assessing information of the strategic initiatives (Time, Budget and Quality) have been rollout.

\subsection{Conclusion}

In the experiment the first three steps were quiet a success. Strategy and strategy maps could be performed well, the OSM has been installed and the new organizational setup was performed. After that the projects get started and with that step, execution of the strategy, problems appeared. The main issue was, that the interaction, the interfaces and the integration of the strategy management level to the tactical and operational level showed major GAP's. These GAP's are described in the next chapter and the solution for closing these GAP's are provided in chapter 5 . 


\section{GAP-ANALYSIS: KAPLAN'S THEORY AND PRAXIS EXPERIMENT}

The GAP-Analysis chapter will show on a researching level where the theories out of Kaplan's thesis have GAP's or are not an appropriate approach to solve concrete business case and execution problem fields.

Before getting into the detailed analysis of gaps per chapter from Kaplan's management system "the execution premium", the most obvious GAP in his book is the fact that there is no designated chapter for "execution". Therefore step 1 and 2 are the development and the planning of the strategy, step 3 to 6 are about how to plan the operations (with respect to organizational issues) and how to monitor, learn and adapt from the execution. But HOW do we execute strategic initiatives, what is an appropriate methodology in form of processes, roles and responsibilities and tools for that part are poorly announced. And how can the interfaces from the methods linked optimal for an integrated system.

\subsection{Step 1 and 2 - development and plan the strategy}

Kaplan is very clear about the definition and formulation of vision, mission and strategy.

In the reality the clear understanding of this three terms are not common and very often mixed up on different levels of the organization. This leads to the problem that everybody in the organization understands something different under these three 
terms. This circumstances make it very difficult to find a formulation which is accepted by all needed parties in the company.

Another question that arises concerns the scope of the business: "Can a single strategy be formulated if the complexity of the business and its related operations is extremely heterogeneous?" For that reason the output of the phase 1 and phase 2 is almost surely provided with a wide variety of different streams of strategy settings.

Another sticking point is the question, which method of strategic analysis should be used. Today there are various from 5 Forces to PESTEL.

The topic of strategic formulation leads to a simple problem. What is strategy? Is it an external view of customers and markets, or an internal view of the marketing mix (or the extended marketing mix on $6 \mathrm{P}$ ) of the company. Do old strategy methods like BCG or Ansoff work out for a solid basis for further planning or are rather complex strategy methods needed?

The results of the experiment show that three main tasks need to be performed within the first phase.

\section{First: Communication Concept}

A clear communication concept needs to be set up. Main scope of the concept should be clearing the terms of mission, vision and strategy in the company's context. After that the content of the three topics (vision, mission, strategy) need to be clearly formulated in a way it can be understand on every single level of the organization.

\section{Second: strategy analysis methods}

As already mentioned there is a great variety of possible methods for strategic analysis. So there needs to be a selection of the best methods providing the optimal data and solutions for all further steps. After performing these methods the last step should 
be the choice of one or a combination of generic strategy approaches. This helps to concentrate on possible planning options within the defined approach.

\section{Third: strategy formulation with respect and linking point to strategy map}

The strategy formulation should be done in the mainframe of the strategic maps as a linking point between strategy development and strategy planning to get seamless integrated findings and an optimal basis for the next phases.

Kaplan describes that strategy planning is the overall planning of initiatives (programs or projects) that closes the gap between the vision and the status quo.

The main issue in performing the experiment was how to prioritize differ strategies roadmaps with respect to limit resources. For example: is closing the gap in the field of market and product positioning and therefore the development of marketrelated services more needed or is it better to contribute to the internal structures gap. This is the balancing act between innovation and efficiency, and therefore a main strategic decision which need to be done in step 1 . But in step 1 not all relevant data is available, especially factor costs for strategic initiatives and programs is in this phase underdeveloped. So there is the need for a main decision: Top-Down costing with a fixed STRATEX budget, which can be assigned to the divers initiatives or setting a feedback loop out of phase 3 and 4 getting reliable data for a prioritization process.

Next GAP in Kaplan's theories is how to manage the big amount of measures that arise with breaking down the strategy map and its initiates to the organizational structure. How are the resources allocated to the many activities and which resources will be distributed. How can initiative programs and projects stuffed with resources that allow an efficient way of managing it? How can I plan the projects without getting the operational management on board? 
The same questions needs to be asked for the task of funding strategic activities. In the experiment and real world the top-down approach of providing a budgeting pool for strategic realization was not given. The Top Management wanted to decide on aggregated numbers with a bottom-up approach. But a look on the process steps from Kaplan shows that these number are in the phase 2 - plan the strategy - not available.

Button Line: the experiment has shown, that the provided methods from Kaplan for these phase: strategy map and BSC were the optimal tools for planning the strategy. STRATEX without any button-up tool from later coming phases was not appropriate in the real world. There need to be a linking element between capacity planning and the tools of the execution phase developed.

\subsection{Step 3 - align the organization}

The alignment of the organization in Kaplan’s system is focused on four main topics:

- Align Business Units

- Align Support Units

- Align Employees

- Install Office of strategy management.

The problem with the mythology in the experiment was that the organization wasn't ready in case of its capacities, structure and culture.

The analysis of the experiment's organization was that the implementation of even a good strategy today is not possible, that there is no appropriate organization of management processes (preparation of decisions, making decisions, communication of 
decisions). This is precisely the reason why the development of the strategy has also to reflect the given organizational environment in step 1 or in the first place a change management projects needs to be performed to develop and implement an organizational model, which fits to the strategic visions and to the fact of operational execution of this visions.

Second issue is that the culture of organizations is an enormous vulnerability. Some organizations are not used to lead to an open discussion of contrary decisions and define a shared decision. There maybe is an organizational form that is initiated in the decisions, but ultimately, all leaders do not act according to the decision, since it has no effects to them. Organizations must learn to make decisions under strategic conditions.

The analysis of the experiment show that the provided steps from Kaplan are fully valid. The realization of these organizational settings need to be made visible and understandable for the complete organization. A dedicated collaboration concept and flanking change management projects need to be developed and realized for an optimal output.

\subsection{Step 4-6 - Plan Operations, Execution, Monitor and Learn, Test and Adapt}

After formulating the strategy and the breakdown and alignment to structure and process organization, the individual measures are planned. But what happens, if the operating budget, the rough planning in relation to the resources that are essential before the alignment of the organization, were far too optimistic and more resources are needed. In this case, there must be a feedback and monitoring strategy and optimal tools, since strategy may need to be adjusted. 
Essential is also the question, how strategy processes with operational planning processes can be synchronized and can be simultaneously anchored in target agreements with employees. Every manager should ultimately from both perspectives have an objective, which is usually but not obvious at all the case. The whole issue of liability of strategies due to the transient nature of staff conditions of senior executives was a big problem. How can I control that the person who has made the strategy two years ago, is also responsible for it now, even though he already has a different role within the company.

The main issue with the monitor and learn and test and adapt steps in Kaplan's system are, that the basis for monitoring, therefore for learning, testing and adaption are information out of the "executing" phase. So the executing phase needs to work with methodologies which are appropriate to perform these two steps. As mentioned in the beginning of chapter 3 the main validated GAP in the system is the "not-workedout" section about execution and its methods. The information of this model are the basis for monitor, learn, test and adapt.

Kaplan concentrates in these phases mostly on budgeting and meeting tools. The experiment shows that an integrated system is needed to react on changes in the plan and develop solid data for re-planning and adjusting the strategic decisions.

\subsection{Conclusion}

Taking a holistically look on the experiment and its analysis within the first two steps a concretization and selection of the provided methods needs to be done. Step three needs a front-up change management project and collaboration model to prepare the organization. Step four to six does not provide necessary methods for execution like 
initiative, program and project management solutions for realizing the strategy. Overall the experiment shows the need of an interacting and integrated model for execution. 


\section{APPROACH FOR BEST-PRACTICE SOLUTION: ISOL-M}

This chapter will focus on developing an integrated model for closing the GAP's provided in chapter 4 and is therefore the main part of this dissertation.

The main focus will be on providing the ISOL-M as a solution closing the GAP's coming from Kaplan's System step "Execution” (process, initiative).

The ISOL-M includes also a solution for the three front-up phases "strategy development", "strategy planning" and "aligning the organization" because of two main reasons. First to show a solution closing the discussed GAP's in these phases, second to show the needed output and interaction from these phases within the ISOL-M.

The chapter will first show an overview of the developed ISOL-M including defined processes, tools and organizational settings.

In the second step all phases of the model will be described. Within these descriptions the evaluation and selection of the best method for every phase and the construction of an integrated realization method system with interacting interfaces will be provided.

\subsection{General approach - PTO}

The PTO (Processes, Tools, Organization) approach is a best-practice approach which aggregates knowledge and proven tool-settings from a bunch of mythologies from process management and organization management as well as from IT management. 
The idea for PTO is that by developing and describing models for companies three levels and the interaction between the levels always need to be considered.

Processes - A process is a sequence of interdependent and linked procedures which, at every stage, consume one or more resources (employee time, energy, machines, money) to convert inputs (data, material, parts, etc.) into outputs. These outputs then serve as inputs for the next stage until a known goal or end result is reached. (http://www.businessdictionary.com/definition/process.html, 2013) With respect to the ISOL-M processes are described as steps to perform the methods within the model.

Tools - A tool in the context of the ISOL-M is a piece of software, a template, or a mixture of both with respect to a method in the ISOL-M.

Organization - The organization level describes who performs the processes or who operates with the tools. The organizational settings are described in the collaboration model. Organization units and organizational roles are connected to processes.

\subsection{ISOL-M - the model}

The ISOL-M model landscape (Figure 26) shows the complete framework for the ISOL-M performed under the conditions of the PTO approach and with defined interfaces and interactions between the phases. 


\section{Phase 1: ISOL-M}
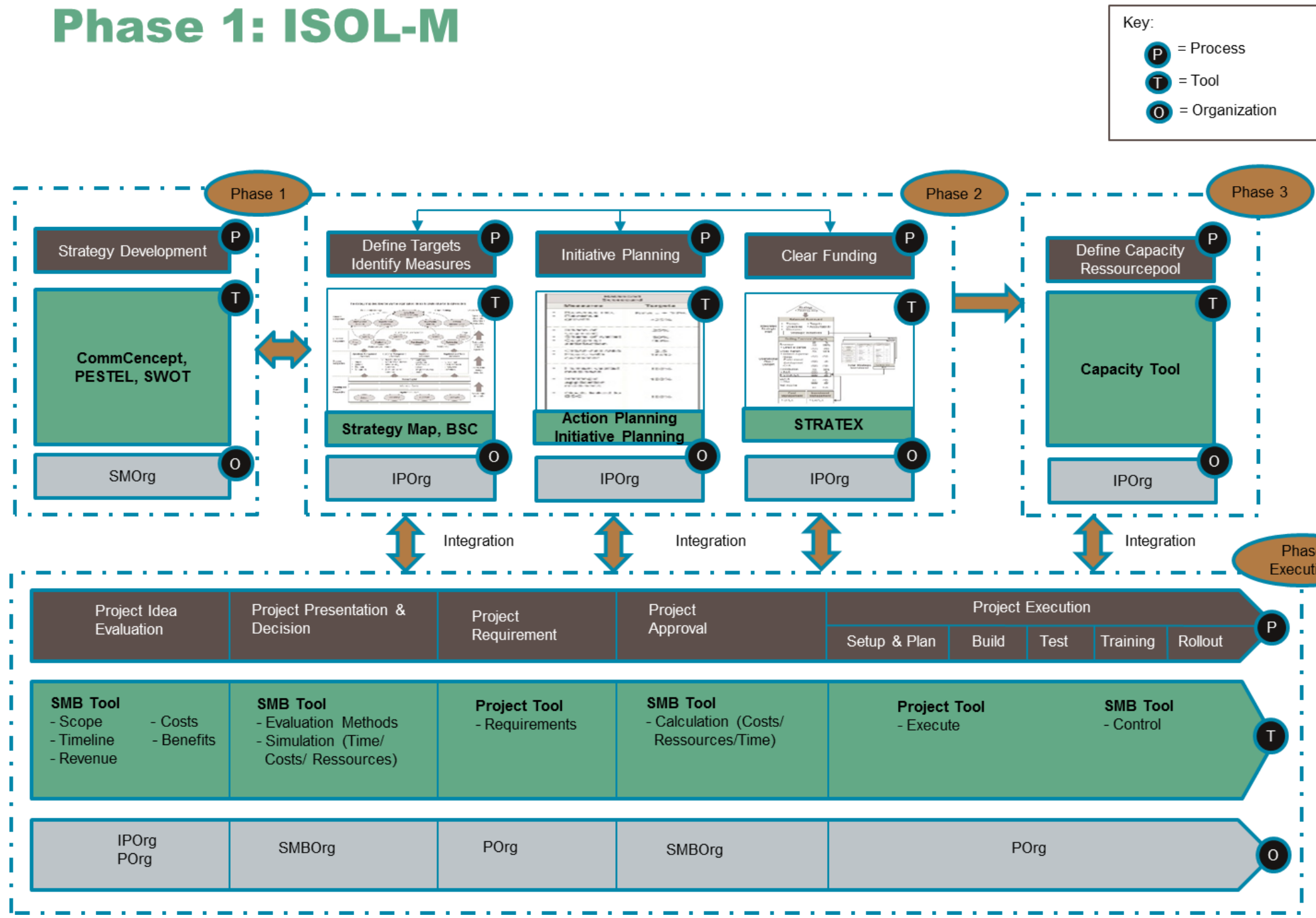

Figure 26: ISOL-M model landscape 


\subsection{Organizational Requirements for ISOL-M}

The ISOL-M model needs a special organizational set-up, which is barely developed at the actual state-of-art company. Even though different studies have shown that getting directors involved in strategy can enhance a company's financial performance and boost stock value. (Strategic Direction, 2008) Strategy execution is often a so called night job, where managers have to fulfill their task in that area besides their normal line work packages. (Kaplan \& Norton, The Execution Premium, 2008)

Therefore the organizational setup is a major topic for a successful implementation of the ISOL-M and that in two ways:

First the described roles must be in place before starting with the implementation of the model. All roles must be aligned to a person. Some roles are explicit designated for only ISOL-M processes. Above that the people must be trained on the ISOL-M processes and tools to get the planned and wanted results with that model.

Second: The organization and its workers and managers must be ready for the ISOL-M regarding their mindset. There must be an open culture for the structure of ISOL-M, a culture which is totally strategy-focused, a culture which has existing structures for process driven models, an efficient meeting culture and is open for change taking over business unit boundaries.

It is recommendable to perform a pre-project to ensure an environment, which is able to handle this change of working line business into strategy-focused, project oriented work. Because converting the strategic vision and high-level goals into implementable actions, is the big challenge of an organization change. (Pellegrinelli, 1997) 
In the following sub-chapters of chapter 5.3 all needed organizational units and roles for the ISOL-M are defined. At the end the connection between processes, roles and responsibilities are presented in form of a RACI.

\subsubsection{Strategic Management Organization (SMOrg)}

The SMOrg needs to have the following members:

Members from the Board Management - Depending on which level of strategy realization the execution should be done one or more members from the board need to be assigned to be part of the SMOrg. If the strategy is a company-wide strategy the CEO needs to be part of it, if it is a strategy related to a special area (e.g. sales, HR) the responsible board member for the area is needed.

Strategy Management Office (SMO) - The strategy Management Office is a new unit, which is essential for the success of the ISOL-M and needs to be performed the way Kaplan describes the setting, tasks and responsibilities. Within the SMOrg the tasks for SMO is to ensure the processes and use of tools and to be the connector between all organizational units within the ISOL-M.

\subsubsection{Initiative and Program Organization (IPOrg)}

The IPOrg is needed to manage and control all activities around initiatives and programs. It is the linking part between project organization and the top-level management.

The IPOrg needs to have the following members:

Initiative/Program Manager - Initiative and program managers are dedicated to manage their programs. They don't have any line responsibility or tasks. 
Line Managers - Line managers need to be in the IPOrg to ensure the "view of reality" is not out of sight within the construct of strategy focusing.

Strategy Management Office (SMO) - Within the IPOrg the tasks for SMO is to ensure the processes and use of tools and to be the connector between the top management level and the IPOrg.

\subsubsection{Project Organization (POrg)}

Project Manager - Project managers are dedicated to manage their programs. They don't have any line responsibility or tasks.

Project Members - Project members are line members or specialist which are needed in the context of the project to deliver sub-work packages with their special know-how.

Project Steering Committee - The project steering committee is an organizational tool from project management theories. It has the function of an escalation forum for problems which cannot be solved in the project team itself and the project manager needs to report to the committee. Normally the initiative manager, the program manager, the project manager are members of the steering committee.

\subsubsection{Strategy Management Board Organization (SMBOrg)}

The SMBOrg is the organization unit, which is responsible for the SMBCouncil. Part of the SMBOrg is the complete IPOrg. With respect to strategic movements and size of projects there could be the need of getting the SMOrg and project managers into this organizational unit. Main organizational driver in the SMBOrg is the SMO. 


\subsubsection{Process and RACI}

The RACI matrix is a common method to show high-level processes and connect them with needed roles. RACI stands for:

- $\mathrm{R}$ - Responsible

- A - Accountable

- $\mathrm{C}-$ Consult

- I - Information

Table 9 shows a generic RACI Model for the ISOL-M.

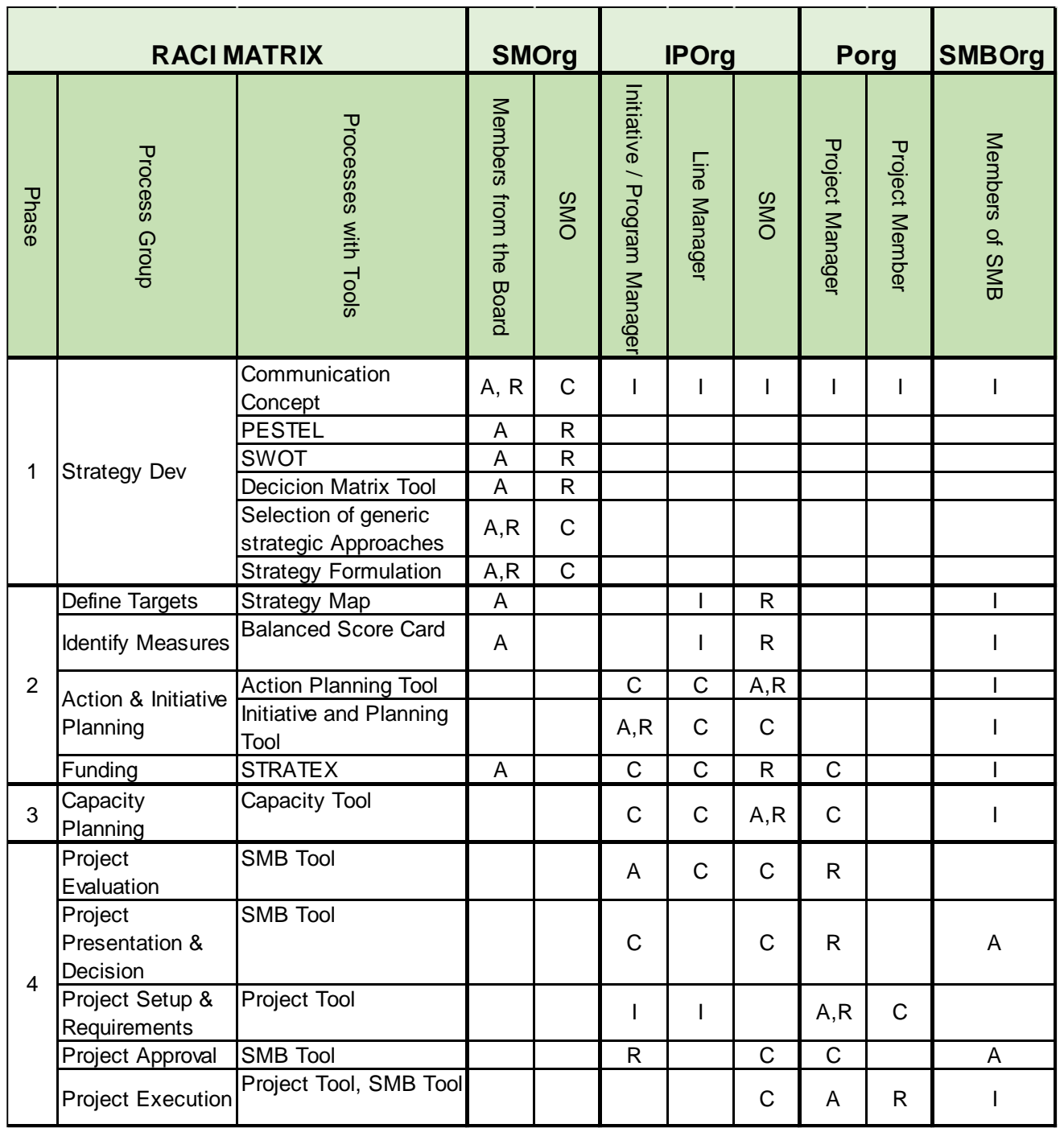

Table 9: RACI 


\subsection{Phase 1: Strategy Development}

As Kaplan stated the main focus of this phase is to perform three main process steps.

a) Definition of mission, values and vision

b) Strategic analysis

c) Strategic formulation

The definition of the mission, company values and vision is an activity defining long-term values for the company. This procedure is done firstly by grounding the company and there should be a yearly review of these three topics. With respect to growth and several external and internal factors there may be the need of adjustment of these topics. However, a main problem of companies is to communicate these values. The external communication to customers and investors is mostly done by providing the information on websites and in annual reports. The internal communication to employees is often neglected or underdeveloped because companies use the same channels and formulations for the internal communication as for external. But there is the need of an extremely more detailed and deep understanding of these terms for internal receivers. Employees need to fully understand the company values for their daily business to act in union with these values. And they need to get a deep understanding of the mission and vision to get on the same train as the management. There is the absolute need of this understanding on the way to a strategy-focused organization and to rise the chances for successful realization of the strategy.

For that reason one of the main issues in the phase of strategy development is providing the tool communication concept. 


\subsubsection{Communication Concept}

\section{Phase 1: Communication Concept}

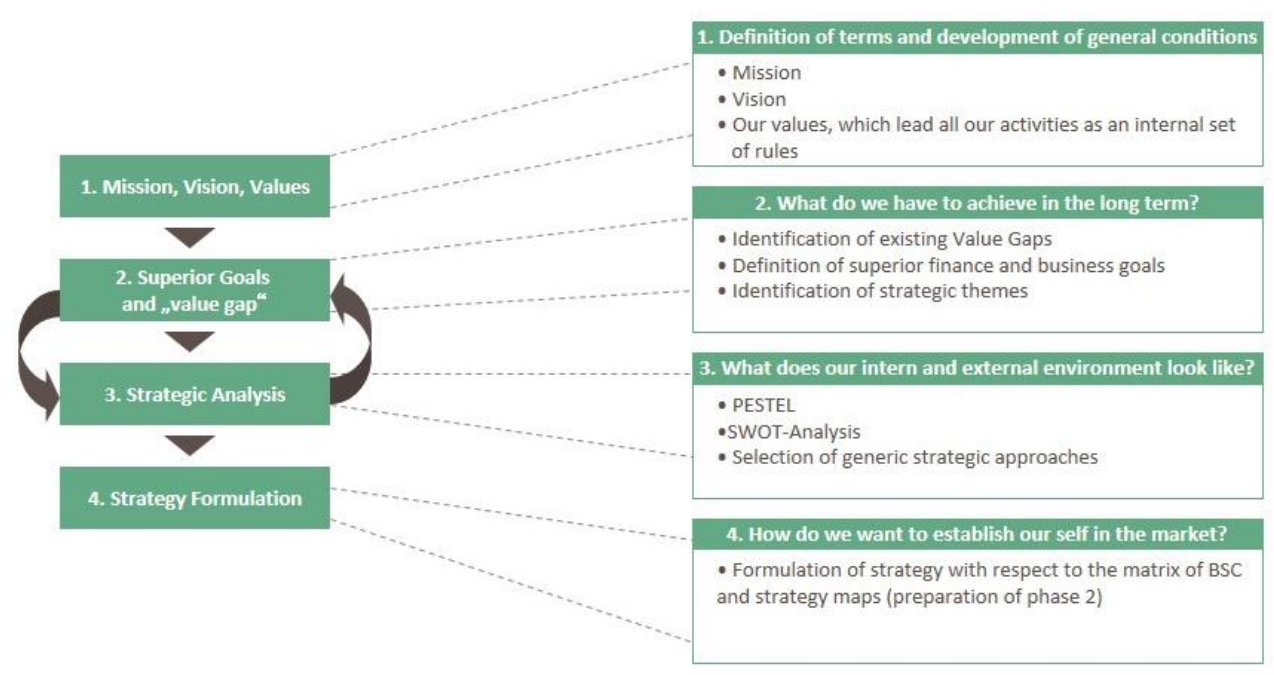

Figure 27: Communication Concept Tool

The communication concept has the following goals:

a) Define the terms of mission, vision and values in a way that every level in the company has the same understanding and state the company's mission, vision and values,

b) Provide the main goals for the future, the actual situation and the GAP's between these two conditions,

c) Provide the results out of strategic analysis and the decision for one or a mix of generic strategic approaches,

d) Provide the results of strategy formulation on a BSC and Strategy Map basis.

\subsubsection{Selection of strategy analysis methods}

As already mentioned there is a great variety of possible methods for strategic analysis. So there needs to be a selection of the best methods providing the optimal data 
and solutions for all further steps. Generally two main aspects need to be covered: External and internal Analysis.

A review of the literature reveals that different approaches and techniques were used for the analysis of macro environment (external analysis). (Lynch, 2009)

With respect to the processes of phase 2 the PESTEL (Table 10) for external analysis seems to be most appropriate.

As Yüksel stated in his article PESTEL analysis mainly provides a general idea about the macro environmental conditions and situation of a company. (Yüksel, 21.11.2012). Lynch provides the following main and sub-factors for PESTEL as shown in below figure.

\section{Phase 1: PESTEL}

\begin{tabular}{|c|c|}
\hline Main factors & Sub-factors \\
\hline (P) POLITICAL & $\begin{array}{l}\text { Relations to countries } \\
\text { Regional Relations } \\
\text { Democratization process } \\
\text { Political stability }\end{array}$ \\
\hline (E) ECONOMICAL & $\begin{array}{l}\text { Net income } \\
\text { Investments } \\
\text { Monetary policy } \\
\text { Fiscal policy } \\
\text { Current deficit } \\
\text { Energy costs } \\
\text { Unemployment }\end{array}$ \\
\hline (S) SOCIAL & $\begin{array}{l}\text { Life style } \\
\text { Level of education } \\
\text { Awareness of citizenship } \\
\text { Obey the rules } \\
\text { Will to work }\end{array}$ \\
\hline (T) TECHOLOGICAL & $\begin{array}{l}\text { Technological investment } \\
\text { New patents } \\
\text { R\&D support }\end{array}$ \\
\hline (E) ENVIRONMENTAL & $\begin{array}{l}\text { Transportation infrastructure } \\
\text { Traffic safety } \\
\text { Public health } \\
\text { Green issues }\end{array}$ \\
\hline (L) LEGAL & $\begin{array}{l}\text { Competition law } \\
\text { Law system } \\
\text { Consumer rights }\end{array}$ \\
\hline
\end{tabular}

Table 10: PESTEL Tool

For the internal analysis the SWOT Tool seems to be appropriate. Helms and Nixon review the SWOT analysis techniques and their deployment over the last decade in the article "exploring SWOT analysis" and state that the SWOT Analysis is one of the major tools for strategy planning. (Nixon\&Helms, 2010). Even if there are critical 
voices like "the SWOT framework, with its vagueness, oversimplified methodology and numerous limitations (Panagiotou, 2003) is a victim of its own success. (Pickton \& Wright, 1998)" Lee and Ko suggest that the SWOT Analysis combined with the BSC make a systematic and holistic strategic management system better. (Lee \& Ko, 2000).

\section{Phase 1: SWOT}

\begin{tabular}{|l|l|l|l|l|}
\hline Business & Strengths & Weaknesses & Opportunities & Threads (Risks) \\
\hline $\begin{array}{l}\text { Processes (Sales, Logistic, } \\
\text { Finance, commercial services) }\end{array}$ & & & & \\
\hline IT & & & & \\
\hline $\begin{array}{l}\text { Innovation Management \& } \\
\text { Products }\end{array}$ & & & & \\
\hline Human Resources & & & & \\
\hline Sales & & & & \\
\hline Price development & & & & \\
\hline Promotion & & & & \\
\hline Logistic & & & & \\
\hline Performance Management & & & \\
\hline Quality Management & & & \\
\hline Risk Management & & & & \\
\hline Customer Service and support & & & & \\
\hline Energy purchase & & & \\
\hline Finances/Controlling & & & \\
\hline Business infrastructure & & & \\
\hline
\end{tabular}

Table 11: SWOT Tool 
These two methods follow the track to an optimal output in form of a decision matrix (Figure 28).

\section{Phase 1: Results of the strategic analysis}

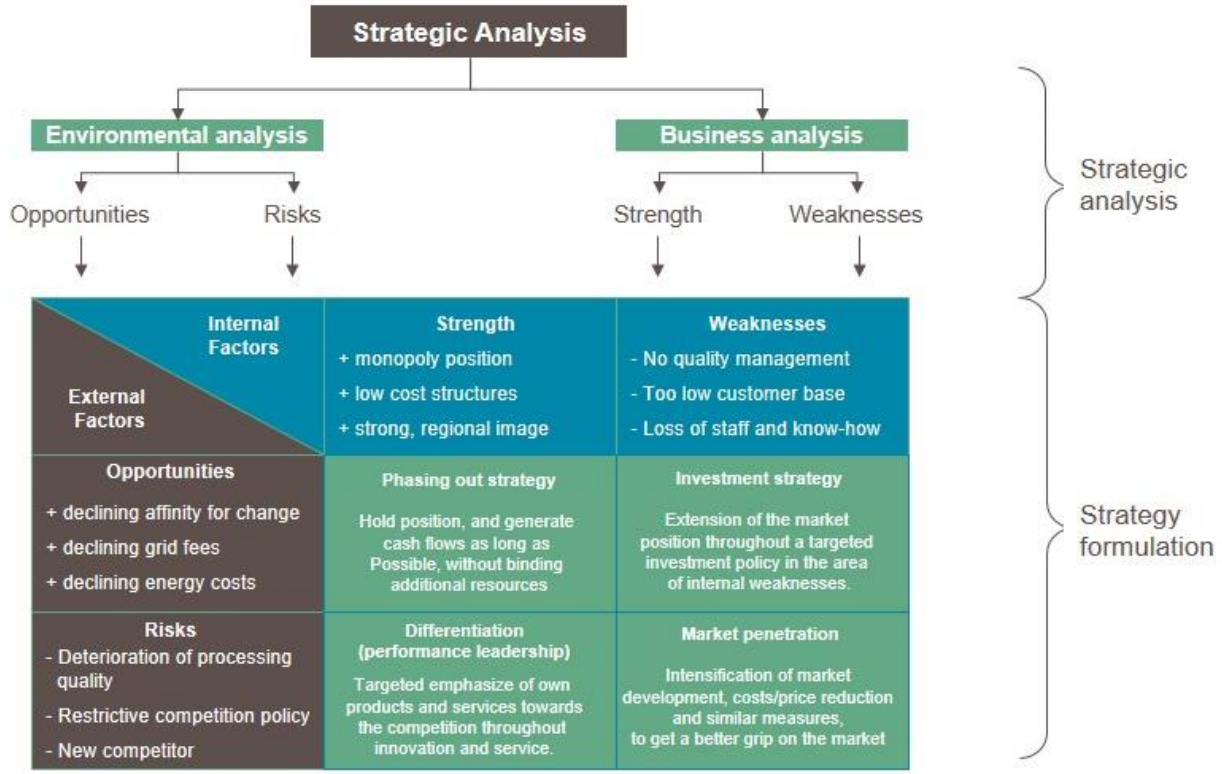

Figure 28: Decision Matrix Tool

\subsubsection{Strategic formulation}

The last step of the strategy development phase is the strategic formulation. This step should provide the clear output for phase 2 and is therefore the interface between these two phases.

The strategic formulation should be built on the results of the strategic analysis and should be performed in a framework that is already a linking element to the strategy maps and BSC in phase 2. The figure below shows the tool which provides optimal interface connection to mentioned tools (strategy map and BSC). 


\section{Phase 1: Strategy formulation}

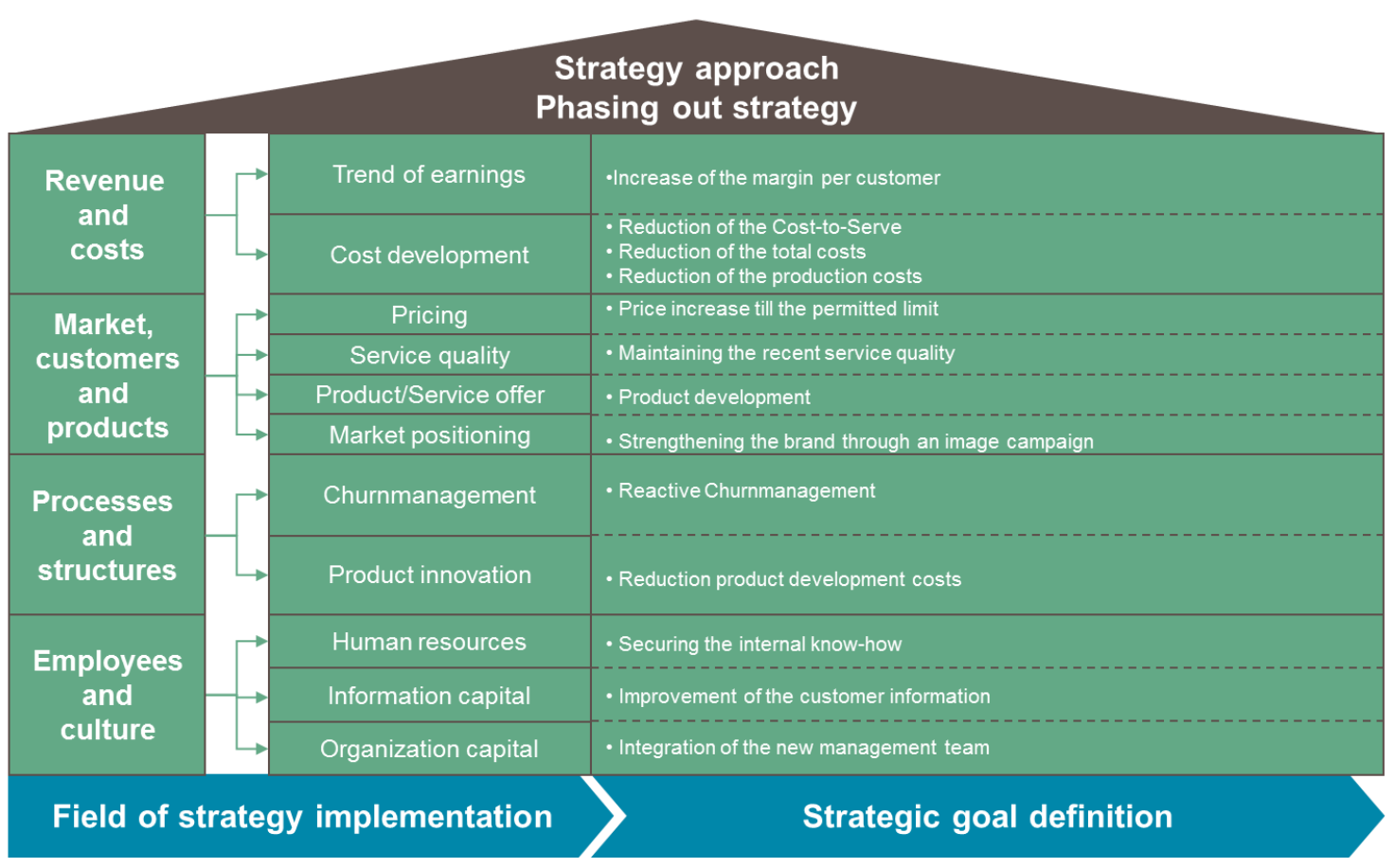

Figure 29: strategy formulation tool

\subsubsection{Organizational responsibility}

All processes and tools within this first phase need to be performed by the organizational unit of SMOrg, because the results of these steps are trendsetting and visionary for the whole company and the responsibility for that is definitely on topmanagement level.

The communication is a top-down communication and there is the need for quality gates to ensure, that everybody understood definitions and content. 


\subsection{Phase 2: Strategy Planning}

In the strategic planning phase two main tasks need to be performed. First: Transferring the strategic goal definition out of phase 1 into realization programs and initiatives, second, clear the funding of these initiatives by calculating STRATEX. The used methodology follows mainly the theories from Kaplan, especially provided in the balanced score card.

\subsubsection{The way to strategic initiatives and programs}

Basis for setting up the strategic initiatives is the strategy formulation from phase 1. As this step was already performed within the matrix of BSC and strategy maps it is obvious that the use of these two tools is appropriate for phase 2 strategic planning.

The first step is to transfer the strategic goals into a strategy map which is build up on the four factors of the BSC (Figure 30).

\section{Phase 2: Strategy map}

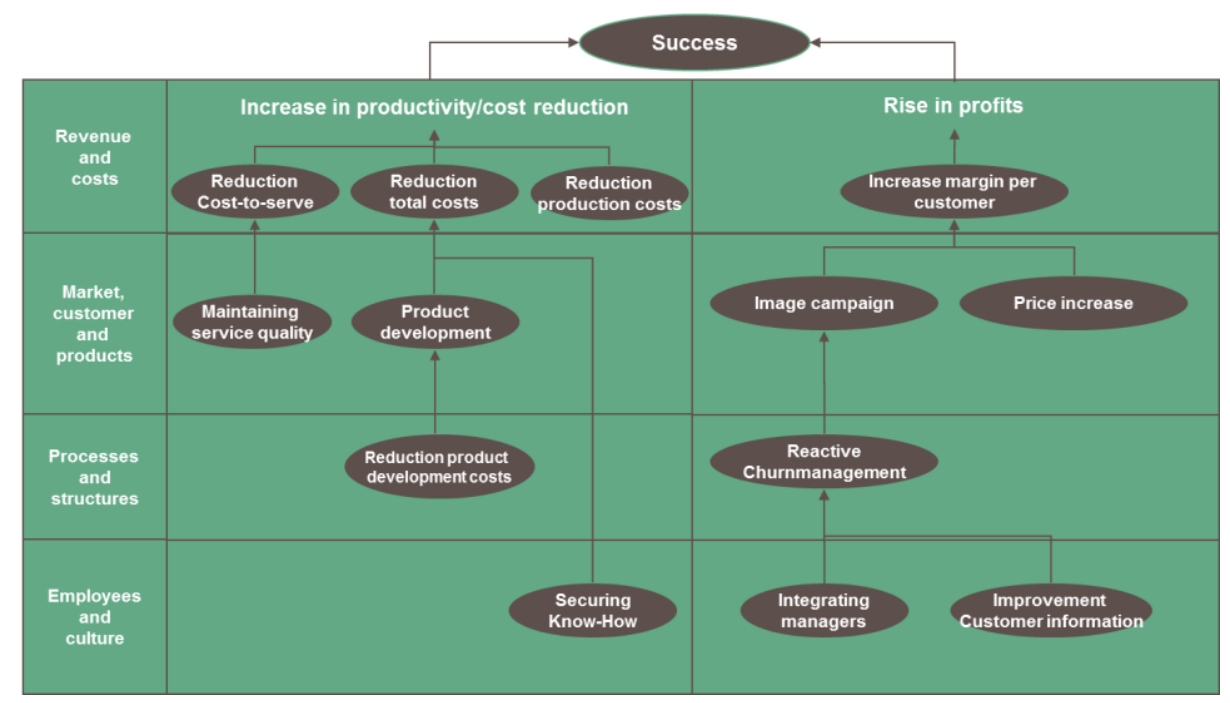

Figure 30: strategy map tool 
In the next step the strategic goals from the strategy map are transmitted to a Balanced Score Card. Within this tool (Table 12) the measurement for the goal needs to be defined as well as the target. In the last step the BSC Index needs to be calculated. For that there is the need of aggregating all planned goals and their targets to a countable BSC Field goal. What is the expected financial output by realizing the goals? This process can sometimes be really tricky, especially if the goals are driven by soft-facts. Kaplan discovers that the data are not available for at least $20 \%$ of the measures on the scorecard. (Kaplan \& Norton, The Balanced Scorecard, 1996). For the ISOL-M there is the absolute need of getting this data and transfer them into "only-Euro"-goals. The last step is to define the BSC Index. This index is an indicator how much value each single goal contributes to the BSC Field goal. The BSC index is a simple percentage indicator. $100 \%$ means the goal takes fully care of the overall BSC Field goal.

\begin{tabular}{|c|c|c|c|c|c|c|}
\hline \multicolumn{7}{|c|}{ BALANCED SCORE CARD } \\
\hline BSC Field & Strategic goal & Measure & Target form & \begin{tabular}{|c|} 
Target \\
value (from \\
actual \\
value)
\end{tabular} & BSC field goal & BSC Index \\
\hline \multirow{4}{*}{$\begin{array}{l}\text { Revenue and } \\
\text { costs }\end{array}$} & Increase of the margin per customer & gross margin per cust. & Increase & $2 \%$ & \multirow{4}{*}{$5.000 .000,00 €$} & $50 \%$ \\
\hline & Reduction of the Cost-to-Serve & Cost-to-serve & Decrease & $5 \%$ & & $20 \%$ \\
\hline & Reduction of the production costs & procurement costs & Decrease & $5 \%$ & & $20 \%$ \\
\hline & Reduction of the total costs & Total costs & Decrease & $2 \%$ & & $10 \%$ \\
\hline \multirow{4}{*}{$\begin{array}{l}\text { Market, } \\
\text { customer and } \\
\text { products }\end{array}$} & Price increase till the permitted limit & gross margin per cust. & Increase & $10 \%$ & \multirow{4}{*}{$1.000 .000,00 €$} & $30 \%$ \\
\hline & $\begin{array}{l}\text { Maintaining the recent service } \\
\text { quality }\end{array}$ & $\begin{array}{l}\text { SLA Terms - Process } \\
\text { Costs }\end{array}$ & Decrease & $5 \%$ & & $30 \%$ \\
\hline & Product development & $\begin{array}{l}\text { Number new products- } \\
\text { new revenue }\end{array}$ & Increase & $2 \%$ & & $30 \%$ \\
\hline & $\begin{array}{l}\text { Strengthening the brand through an } \\
\text { image campaign }\end{array}$ & $\begin{array}{l}\text { Number of campaigns- } \\
\text { new revenue }\end{array}$ & Increase & $1 \%$ & & $10 \%$ \\
\hline \multirow{2}{*}{$\begin{array}{l}\text { Processes and } \\
\text { structure }\end{array}$} & Reactive Churnmanagement & $\begin{array}{l}\text { Churnrate - costs for } \\
\text { new customers }\end{array}$ & Decrease & $10 \%$ & \multirow{2}{*}{$1.000 .000,00 €$} & $60 \%$ \\
\hline & $\begin{array}{l}\text { Reduction of product development } \\
\text { costs }\end{array}$ & $\begin{array}{l}\text { Developed Products - } \\
\text { costs }\end{array}$ & Decrease & $5 \%$ & & $40 \%$ \\
\hline \multirow{3}{*}{ Staff and culture } & Securing the internal know-how & $\begin{array}{l}\text { documentation - } \\
\text { reusability - costs }\end{array}$ & Decrease & $10 \%$ & \multirow{3}{*}{$50.000,00 €$} & $60 \%$ \\
\hline & $\begin{array}{l}\text { Improvement of the customer } \\
\text { information }\end{array}$ & $\begin{array}{l}\text { Know How Index - new } \\
\text { asset revenue }\end{array}$ & Increase & $2 \%$ & & $20 \%$ \\
\hline & $\begin{array}{l}\text { Integration of the new management } \\
\text { team }\end{array}$ & $\begin{array}{l}\text { Quality of processes - } \\
\text { costs }\end{array}$ & Decrease & $5 \%$ & & $20 \%$ \\
\hline
\end{tabular}

Table 12: BSC Tool

The next process is to develop actions in form of an action planning tool (Table 13), which helps the company to achieve the defined goals. These actions should be developed on a single goal basis. For every action an action index must be calculated. This action index is an indicator how much value the action brings to the goal. Probably 
there is the need for more than one action to fulfil a goal so a set of actions is needed. The action index is a simple percentage indicator. $100 \%$ means the action takes fully care of the target.

\begin{tabular}{|c|c|c|c|c|c|c|}
\hline \multicolumn{5}{|c|}{ BALANCED SCORE CARD } & \multicolumn{2}{|c|}{ ACTION PLANNING } \\
\hline BSC Field & Strategic goal & Measure & Target form & $\begin{array}{c}\text { Target } \\
\text { value (from } \\
\text { actual } \\
\text { value) } \\
\end{array}$ & Action & Action Index \\
\hline \multirow{4}{*}{$\begin{array}{l}\text { Revenue and } \\
\text { costs }\end{array}$} & Increase of the margin per customer & gross margin per cust. & Increase & $2 \%$ & Action 1 & $100 \%$ \\
\hline & Reduction of the Cost-to-Serve & Cost-to-serve & Decrease & $5 \%$ & Action 2 & $100 \%$ \\
\hline & Reduction of the production costs & procurement costs & Decrease & $5 \%$ & Action 3 & $100 \%$ \\
\hline & Reduction of the total costs & Total costs & Decrease & $2 \%$ & Action 4 & $100 \%$ \\
\hline \multirow{4}{*}{$\begin{array}{c}\text { Market, } \\
\text { customer and } \\
\text { products }\end{array}$} & Price increase till the permitted limit & gross margin per cust. & Increase & $10 \%$ & Action 5 & $100 \%$ \\
\hline & $\begin{array}{l}\text { Maintaining the recent service } \\
\text { quality }\end{array}$ & $\begin{array}{l}\text { SLA Terms - Process } \\
\text { Costs }\end{array}$ & Decrease & $5 \%$ & Action 6 & $100 \%$ \\
\hline & Product development & $\begin{array}{l}\text { Number new products- } \\
\text { new revenue }\end{array}$ & Increase & $2 \%$ & Action 7 & $100 \%$ \\
\hline & $\begin{array}{l}\text { Strengthening the brand through an } \\
\text { image campaign }\end{array}$ & $\begin{array}{l}\text { Number of campaigns- } \\
\text { new revenue }\end{array}$ & Increase & $1 \%$ & Action 8 & $100 \%$ \\
\hline \multirow{2}{*}{$\begin{array}{l}\text { Processes and } \\
\text { structure }\end{array}$} & Reactive Churnmanagement & $\begin{array}{l}\text { Churnrate - costs for } \\
\text { new customers }\end{array}$ & Decrease & $10 \%$ & Action 9 & $100 \%$ \\
\hline & $\begin{array}{l}\text { Reduction of product development } \\
\text { costs }\end{array}$ & $\begin{array}{l}\text { Developed Products - } \\
\text { costs }\end{array}$ & Decrease & $5 \%$ & Action 10 & $100 \%$ \\
\hline \multirow{4}{*}{ Staff and culture } & Securing the internal know-how & $\begin{array}{l}\text { documentation - } \\
\text { reusability - costs }\end{array}$ & Decrease & $10 \%$ & Action 11 & $100 \%$ \\
\hline & \multirow{2}{*}{$\begin{array}{l}\text { Improvement of the customer } \\
\text { information }\end{array}$} & \multirow{2}{*}{$\begin{array}{l}\text { Know How Index - new } \\
\text { asset revenue }\end{array}$} & \multirow{2}{*}{ Increase } & \multirow{2}{*}{$2 \%$} & Action 12 & $60 \%$ \\
\hline & & & & & Action 13 & $40 \%$ \\
\hline & $\begin{array}{l}\text { Integration of the new management } \\
\text { team }\end{array}$ & $\begin{array}{l}\text { Quality of processes - } \\
\text { costs }\end{array}$ & Decrease & $5 \%$ & Action 14 & $100 \%$ \\
\hline
\end{tabular}

Table 13: Action Planning Tool

The last step is to merge several actions into initiatives or programs. For an optimal merge a merging matrix with possible merging values needs to be developed. These values can be chosen differently from company to company. Possible values are shown in Table 14. In the below case two initiatives (optimization and innovation) have been defined. Under each initiative two programs (increase margin, decrease costs) have been set up. Under these programs several actions are placed. 


\begin{tabular}{|c|c|c|c|c|c|}
\hline BSC & ACTION P & ANNING & INITIAT & IVE / PROGRAI & M PLANNING \\
\hline BSC Field & $\begin{array}{l}\text { Action } \\
\qquad\end{array}$ & $\begin{array}{l}\text { Action } \\
\text { Index }\end{array}$ & $\begin{array}{c}\text { form } \\
\text { (initiative) } \\
\end{array}$ & $\begin{array}{c}\text { financial impact } \\
\text { (program) }\end{array}$ & $\begin{array}{l}\text { Business Unit } \\
\text { (operative } \\
\text { responsibility) }\end{array}$ \\
\hline & Action 1 & $100 \%$ & Optimization & increase margin & direct sales \\
\hline Revenue and costs & Action 2 & $100 \%$ & Optimization & decrease costs & sales support \\
\hline & Action 3 & $100 \%$ & Optimization & decrease costs & procurement \\
\hline & Action 4 & $100 \%$ & Optimization & decrease costs & sales controlling \\
\hline & Action 5 & $100 \%$ & Optimization & decrease costs & direct sales \\
\hline & Action 6 & $100 \%$ & Optimization & decrease costs & sales support \\
\hline and products & Action 7 & $100 \%$ & Innovation & increase margin & product management \\
\hline & Action 8 & $100 \%$ & Innovation & decrease costs & sales support \\
\hline sses and & Action 9 & $100 \%$ & Optimization & decrease costs & product management \\
\hline & Action 10 & $100 \%$ & Optimization & decrease costs & sales support \\
\hline & Action 11 & $100 \%$ & Optimization & decrease costs & sales support \\
\hline Sta & Action 12 & $60 \%$ & Innovation & increase margin & sales IT \\
\hline Stall aria curture & Action 13 & $40 \%$ & Innovation & increase margin & sales IT \\
\hline & Action 14 & $100 \%$ & Optimization & decrease costs & sales management \\
\hline
\end{tabular}

Table 14: Initiative and Program Planning Tool

The next upcoming processes are

a) Clear funding of the initiatives. This step will be performed with STRATEX (next chapter)

b) Transfer the actions into realization projects. This step will be performed in phase 4, step 1: project idea evaluation.

\subsubsection{Integrated STRATEX tool}

The funding of the strategic plans and actions will be performed within the STRATEX tool.

As already stated in the GAP Analysis, STRATEX cannot be performed without any funded data. For that reason the setup of the capacity tool (phase 3) and the first step of the execution phase "project idea evaluation" need to be done first. These two 
tools deliver reasonable data for calculating STRATEX. The approach that a company sets up a strategic budget without that data, but for example a ratio of sales revenue or overall revenue seams very seldom.

Pretending the capacity tool and the project idea evaluation are already performed the STRATEX calculation can be done as shown in Table 15.

\begin{tabular}{|c|c|c|c|c|c|c|}
\hline \multicolumn{7}{|c|}{ STRATEX } \\
\hline Initiative & costs per init & program & $\begin{array}{l}\text { costs per } \\
\text { program }\end{array}$ & projects & $\begin{array}{l}\text { costs per } \\
\text { project }\end{array}$ & Action \\
\hline \multirow{4}{*}{ Innovation } & \multirow{4}{*}{$90.960,39 €$} & decrease costs & $50.000,00 €$ & project 1 & $50.000,00 €$ & Action 8 \\
\hline & & \multirow{3}{*}{ increase margin } & \multirow{3}{*}{$40.960,39 €$} & \multirow{2}{*}{ project 2} & \multirow{2}{*}{$37.210,39 €$} & Action 7 \\
\hline & & & & & & Action 12 \\
\hline & & & & project 3 & $3.750,00 €$ & Action 13 \\
\hline \multirow{10}{*}{ Optimazation } & \multirow{10}{*}{$3.450 .000,00 €$} & \multirow{9}{*}{ decrease costs } & \multirow{9}{*}{$1.200 .000,00 €$} & proiect 4 & \multirow{2}{*}{$250.000,00 €$} & Action 2 \\
\hline & & & & 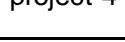 & & Action 3 \\
\hline & & & & \multirow{3}{*}{ project 5} & \multirow{3}{*}{$100.000,00 €$} & Action 4 \\
\hline & & & & & & Action 5 \\
\hline & & & & & & Action 6 \\
\hline & & & & \multirow{4}{*}{ project 6} & \multirow{4}{*}{$850.000,00 €$} & Action 9 \\
\hline & & & & & & Action 10 \\
\hline & & & & & & Action 11 \\
\hline & & & & & & Action 14 \\
\hline & & increase margin & $2.250 .000,00 €$ & project 7 & $2.250 .000,00 €$ & Action 1 \\
\hline
\end{tabular}

TOTAL $\quad 3.540 .960,39 €$

Table 15: STRATEX Tool

As Baldwin and Clark stated many companies do not link their investments to long-term strategic priorities. (Baldwin \& Clark, 1994)

But the company needs to fund the TOTAL STRATEX amount in their overall budget planning. The advantage of calculating with STRATEX is, that strategic expenses can be controlled under the same condition as operational expenses and revenues and all controlling KPI's like cost-effectiveness on strategies, ROI on strategies can be performed. 


\subsubsection{Organizational responsibility}

All processes and tools within this second phase need to be performed by the organizational unit of IPOrg. As this phase is the connection between top level management processes and middle management processes the IPOrg has a mixed setting of managers (see chapter IPOrg). The SMO is responsible for managing and controlling the transformation of the results of phase 1 to phase 2. And they need to specify the target measurements and index with the top management, for defined strategic goals from phase 1 . The initiative and program manager are responsible for performing the initiative and program tool and the line managers are on board for a realistic view on possible actions and their outputs with respect of calculating STRATEX.

\subsection{Phase 3: Capacity Setup}

Resources are a limiting factor for companies to execute their strategies. In the strategy realization business the focus is on human resources.

So after developing and planning the strategy in phase 1 and phase 2 , the next step is to setup a framework which delivers the following information (Table 16):

a) Resource pool of possible resources (internal, external)

b) Availability of resources

c) Skills of the resource / appropriate resource alignment

d) Costs of the resource

Above that the capacity tool keeps resource master data like personal data per person, holiday planning, substitutes, alignment to organizational units, and alignment to role model and position. 
The capacity tool has a direct influence and interface with the tools of STRATEX and the SMB Tool. It delivers costs to STRATEX and possible organizational setups with respect to appropriate skills and availability for the SMB Tool for the projects. 


\begin{tabular}{|c|c|c|c|c|c|c|c|c|c|c|c|}
\hline \multicolumn{12}{|c|}{ CAPACITY TOOL } \\
\hline Name & Org. Unit & Substitute & $\begin{array}{l}\text { ISOL-M } \\
\text { skills }\end{array}$ & Line role & Position & contract & Costs per Year & $\begin{array}{l}\text { Costs per } \\
\text { day }\end{array}$ & $\begin{array}{l}\text { booked on } \\
\text { line activities }\end{array}$ & $\begin{array}{l}\text { booked on } \\
\text { ISOL-M } \\
\text { activities } \\
\end{array}$ & utilisation \\
\hline Person 1 & Unit 1 & Person 2 & $\begin{array}{l}\text { program } \\
\text { manager }\end{array}$ & none & & internal & $100.000,00 €$ & $454,55 €$ & \multirow{10}{*}{$\begin{array}{c}\text { monthly day by } \\
\text { day calender } \\
\text { with data in \% } \\
\text { of line activities }\end{array}$} & \multirow{10}{*}{$\begin{array}{c}\text { monthly day } \\
\text { by day } \\
\text { calender with } \\
\text { data in \% of } \\
\text { ISOL-M } \\
\text { activities. } \\
\text { Data input } \\
\text { from SMB } \\
\text { Tool (project } \\
\text { idea } \\
\text { evaluation for } \\
\text { planned } \\
\text { booking, } \\
\text { project } \\
\text { execution for } \\
\text { as-is } \\
\text { bookings }\end{array}$} & \multirow{10}{*}{$\begin{array}{c}\text { monthly day } \\
\text { by day } \\
\text { calender with } \\
\text { calculated } \\
\text { utilisation } \\
\text { rate } \\
\text { (possible } \\
\text { availability } \\
\text { minus } \\
\text { booked } \\
\text { activities) }\end{array}$} \\
\hline Person 2 & Unit 2 & Person 3 & $\begin{array}{l}\text { initiative } \\
\text { manager }\end{array}$ & none & & internal & $150.000,00 €$ & $681,82 €$ & & & \\
\hline Person 3 & Unit 3 & Person 4 & $\begin{array}{l}\text { OSM } \\
\text { manager } \\
\end{array}$ & none & & internal & $90.000,00 €$ & $409,09 €$ & & & \\
\hline Person 4 & Unit 4 & Person 5 & $\begin{array}{l}\text { project } \\
\text { manager }\end{array}$ & none & & external & - & $1.000,00 €$ & & & \\
\hline Person 5 & Unit 5 & Person 6 & $\begin{array}{l}\text { project } \\
\text { member }\end{array}$ & $\begin{array}{l}\text { Unit } \\
\text { member }\end{array}$ & $\begin{array}{l}\text { sales } \\
\text { admin }\end{array}$ & internal & $60.000,00 €$ & $272,73 €$ & & & \\
\hline Person 6 & Unit 6 & Person 7 & $\begin{array}{l}\text { project } \\
\text { member }\end{array}$ & Unit lead & $\begin{array}{l}\text { sales } \\
\text { manager }\end{array}$ & internal & $75.000,00 €$ & $340,91 €$ & & & \\
\hline Person 7 & Unit 7 & Person 8 & $\begin{array}{l}\text { project } \\
\text { member }\end{array}$ & $\begin{array}{l}\text { Unit } \\
\text { member }\end{array}$ & $\begin{array}{l}\text { support } \\
\text { admin }\end{array}$ & internal & $60.000,00 €$ & $272,73 €$ & & & \\
\hline Person 8 & Unit 8 & Person 9 & $\begin{array}{l}\text { project } \\
\text { member }\end{array}$ & $\begin{array}{l}\text { Unit } \\
\text { member }\end{array}$ & $\begin{array}{l}\text { support } \\
\text { admin }\end{array}$ & internal & $60.000,00 €$ & $272,73 €$ & & & \\
\hline Person 9 & Unit 9 & Person 10 & $\begin{array}{l}\text { project } \\
\text { member }\end{array}$ & $\begin{array}{l}\text { Unit } \\
\text { member }\end{array}$ & $\begin{array}{l}\text { support } \\
\text { admin }\end{array}$ & internal & $60.000,00 €$ & $272,73 €$ & & & \\
\hline Person 10 & Unit 10 & Person 11 & $\begin{array}{l}\text { project } \\
\text { member }\end{array}$ & none & & extern & 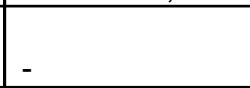 & $800,00 €$ & & & \\
\hline
\end{tabular}




\subsection{Phase 4: Execution}

Phase 4 is dedicated to the model of execution. The model includes the following five process steps (see Figure 31).

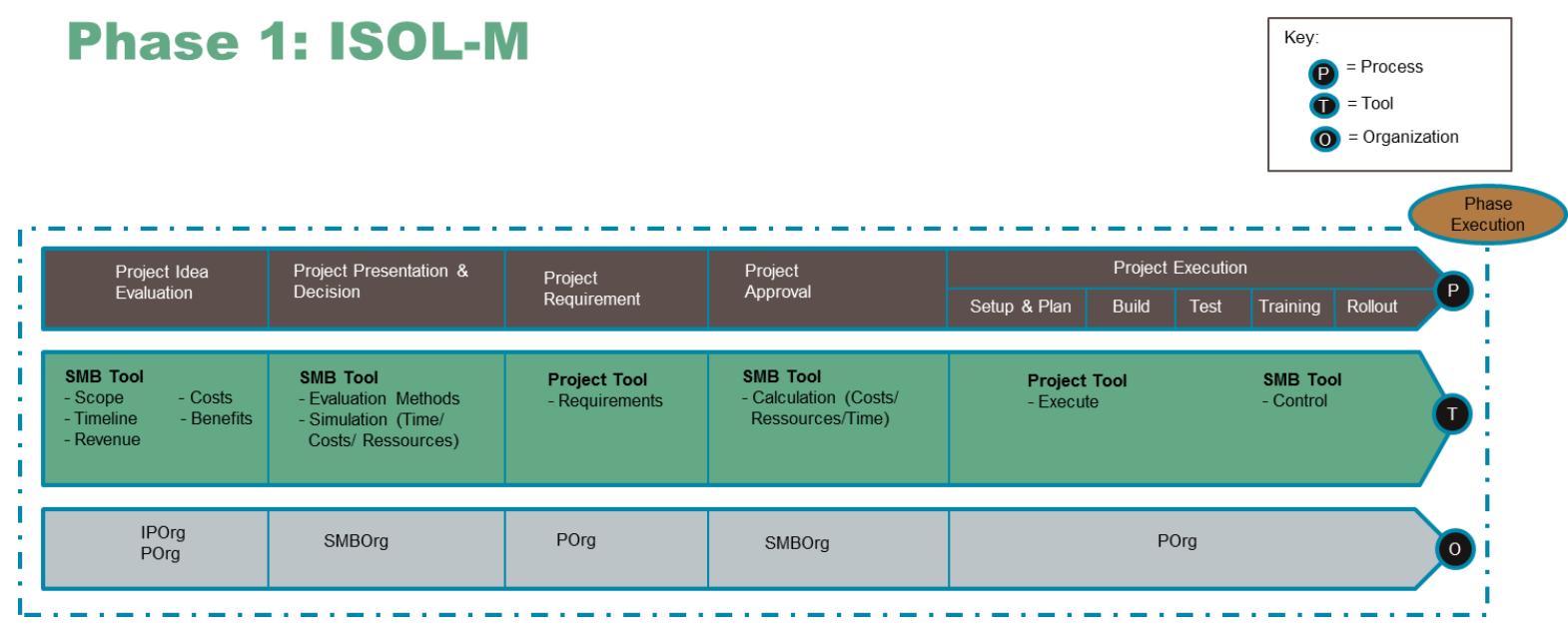

Figure 31: Execution Overview

In the following chapters a detailed description of processes, tools and organizational responsibility for every process step is provided with respect of the use of results from front-up phases 1-3 and interfaces between the phases. Two main tools are developed and needed for this phase. First the SMB Tool which is responsible to evaluate, plan and control all project activities with the focus on multi-project management. Second a project tool is needed, which helps to plan and execute every single project with a generic approach.

\subsubsection{Step 1: Project Idea Evaluation}

In line with the suggestion that prior to commencing a project, the need for highlevel requirements may be documented as part of a larger organization initiative (Project Management Institute, 2013), the organizational initiative has been concluded by the BSC. Therefore, the next step is to evaluate project ideas with respect to the 
defined strategy actions and in the framework of the initiative and program planning results.

Starting point for the project idea evaluation is the initiative overview from the initiative planning overview (Table 17: SMB Tool Evaluation Start).

\begin{tabular}{|c|c|c|c|c|c|c|c|}
\hline \multicolumn{2}{|c|}{ ACTION PLANNING } & \multicolumn{6}{|c|}{ INITIATIVE / PROGRAM PLANNING / PROJECT } \\
\hline Action & Action Index & $\begin{array}{c}\text { form } \\
\text { (initiative) }\end{array}$ & $\begin{array}{c}\text { financial } \\
\text { impact } \\
\text { (program) }\end{array}$ & $\begin{array}{l}\text { Business Unit } \\
\text { (operative } \\
\text { responsibility) }\end{array}$ & Initiative & program & projects \\
\hline Action 8 & $100 \%$ & Innovation & decrease costs & sales support & \multirow{4}{*}{ Innovation } & decrease costs & project 1 \\
\hline Action 7 & $100 \%$ & Innovation & increase margin & product management & & \multirow{3}{*}{ increase margin } & \multirow{2}{*}{ project 2} \\
\hline Action 12 & $60 \%$ & Innovation & increase margin & sales IT & & & \\
\hline Action 13 & $40 \%$ & Innovation & increase margin & sales IT & & & project 3 \\
\hline Action 2 & $100 \%$ & Optimazation & decrease costs & sales support & \multirow{10}{*}{ Optimazation } & \multirow{9}{*}{ decrease costs } & \multirow{2}{*}{ project 4} \\
\hline Action 3 & $100 \%$ & Optimazation & decrease costs & procurement & & & \\
\hline Action 4 & $100 \%$ & Optimazation & decrease costs & sales controlling & & & \multirow{3}{*}{ project 5} \\
\hline Action 5 & $100 \%$ & Optimazation & decrease costs & direct sales & & & \\
\hline Action 6 & $100 \%$ & Optimazation & decrease costs & sales support & & & \\
\hline Action 9 & $100 \%$ & Optimazation & decrease costs & product management & & & \multirow{4}{*}{ project 6} \\
\hline Action 10 & $100 \%$ & Optimazation & decrease costs & sales support & & & \\
\hline Action 11 & $100 \%$ & Optimazation & decrease costs & sales support & & & \\
\hline Action 14 & $100 \%$ & Optimazation & decrease costs & sales management & & & \\
\hline Action 1 & $100 \%$ & Optimazation & increase margin & direct sales & & increase margin & project 7 \\
\hline
\end{tabular}

Table 17: SMB Tool Evaluation Start

The initiative or program manager sets up a new project in the SMB Tool. The first part of the SMB Tool is the evaluation sheet. In this sheet the following information are transferred:

- Project name

- Connection to program and initiative

- Form, financial impact and business unit

- Transfer actions to project goal topics

- Actions details 


\begin{tabular}{|c|c|c|c|c|c|c|}
\hline \multicolumn{3}{|c|}{ Project Name } & \multicolumn{3}{|c|}{ Initiative } & Program \\
\hline \multicolumn{3}{|c|}{ Project 2} & \multicolumn{3}{|c|}{ Innovation } & increase margin \\
\hline \multicolumn{3}{|c|}{ Form } & \multicolumn{3}{|c|}{ Financial Impact } & \\
\hline \multicolumn{3}{|c|}{ Innovation } & \multicolumn{3}{|c|}{ increase margin } & \\
\hline \multicolumn{3}{|c|}{ Project Goals } & \multicolumn{3}{|c|}{ Action Indicator } & Business Units \\
\hline \multicolumn{3}{|c|}{ Action 7} & \multicolumn{3}{|c|}{100} & product management \\
\hline \multicolumn{3}{|c|}{ Action 12} & \multicolumn{3}{|c|}{60} & sales IT \\
\hline \multicolumn{7}{|c|}{ Project Idea } \\
\hline \multicolumn{3}{|c|}{ Project Ideas } & \multicolumn{3}{|c|}{ Project Scope } & Project Delivery Objects \\
\hline \multicolumn{3}{|c|}{$\begin{array}{c}\text { Ideas for Realization dedicated to action } 7 \\
\text { Ideas for Realization dedicated to action } 12\end{array}$} & \multicolumn{3}{|c|}{$\begin{array}{c}\text { Defined Scope: What are the needed } \\
\text { changes, new developments to realize the } \\
\text { ideas? }\end{array}$} & $\begin{array}{c}\text { What is the wanted output in form of new } \\
\text { systems, processes, etc. with respect to the } \\
\text { project scope? }\end{array}$ \\
\hline \multicolumn{3}{|c|}{ Project Environment } & \multicolumn{3}{|c|}{ Project Restrictions } & High Level Requirements \\
\hline \multicolumn{3}{|c|}{$\begin{array}{l}\text { Description of the environment (market, } \\
\text { customers, IT, senvices, organization) }\end{array}$} & \multicolumn{3}{|c|}{ Description of restrictions to the project } & $\begin{array}{c}\text { Definition of High Level Requirements in form } \\
\text { of business concepts. Basis for capacity and } \\
\text { cost approach }\end{array}$ \\
\hline \multicolumn{7}{|c|}{ Project Timing } \\
\hline \multicolumn{3}{|c|}{ Planned Start Date } & \multicolumn{3}{|c|}{ Planned End Date } & Time Restrictions \\
\hline \multicolumn{3}{|c|}{01.01 .2014} & \multicolumn{3}{|c|}{01.03 .2014} & $\begin{array}{c}\text { Given Start or End Dates by external } \\
\text { restrictions }\end{array}$ \\
\hline \multicolumn{7}{|c|}{ Project Organization } \\
\hline \multicolumn{3}{|c|}{ Project manager } & \multicolumn{3}{|c|}{ Program Manager } & Initiative Manager \\
\hline & Person 4 & & & Person 1 & & Person 2 \\
\hline & Project Team & & & Project Team & & Project Team \\
\hline & Person 5 & & & Person 6 & & Person 10 \\
\hline & & & & roject Cost & & \\
\hline${ }^{\text {*Effort appro }}$ & h for realization & evel $r$ & nents & & & \\
\hline Person & Days & & eff. Days & Costs/day & Total & Total Costs \\
\hline Person 4 & 42 & $30 \%$ & 12,6 & $1.000,00 €$ & $12.642,86 €$ & $37.210,39 €$ \\
\hline Person 1 & 42 & $20 \%$ & 8,4 & $454,55 €$ & $3.831,17 €$ & \\
\hline Person 2 & 42 & $5 \%$ & 2,1 & $681,82 €$ & $1.436,69 €$ & \\
\hline Person 5 & 42 & $50 \%$ & 21,1 & $272,73 €$ & $5.746,75 €$ & \\
\hline Person 6 & 42 & $30 \%$ & 12,6 & $340,91 €$ & $4.310,06 €$ & \\
\hline Person 10 & 42 & $20 \%$ & 8,4 & $800,00 €$ & $6.742,86 €$ & \\
\hline ex. Supplier & - & $100 \%$ & & & $2.500,00 €$ & \\
\hline
\end{tabular}

Figure 32: SMB Tool - project idea evaluation

In the next step the program manager defines the dedicated project manager and performs the project idea evaluation processes.

First project ideas need to be generated with the focus of operational realization for scoring the project goals (actions). In the second step from this ideas the project scope needs to be described. Sometimes it is very useful to define the non-scope of the 
project. With the project scope the concrete project delivery objects can be setup. The first draft of the project scope however, is not fixed, but is defined and described with great specificity as more information about the project is known. (Project Management Institute, 2013) In the last step of the project idea phase the project environment and possible restrictions need to be defined, since changes to project objectives affect project efficiency and success (Project Management Institute, 2013).

After that step a high level requirement document in form of a business concept needs to be performed. This document is the basis for the further step of effort approaching.

The next step is to define the project timing and the project organization. The results of these two definitions are the basis for the calculation of the project costs. The complete process is shown in the process chart (Figure 33).

The responsibility for the complete process is in the POrg, especially the project manager. 


\section{Project Idea Evaluation}
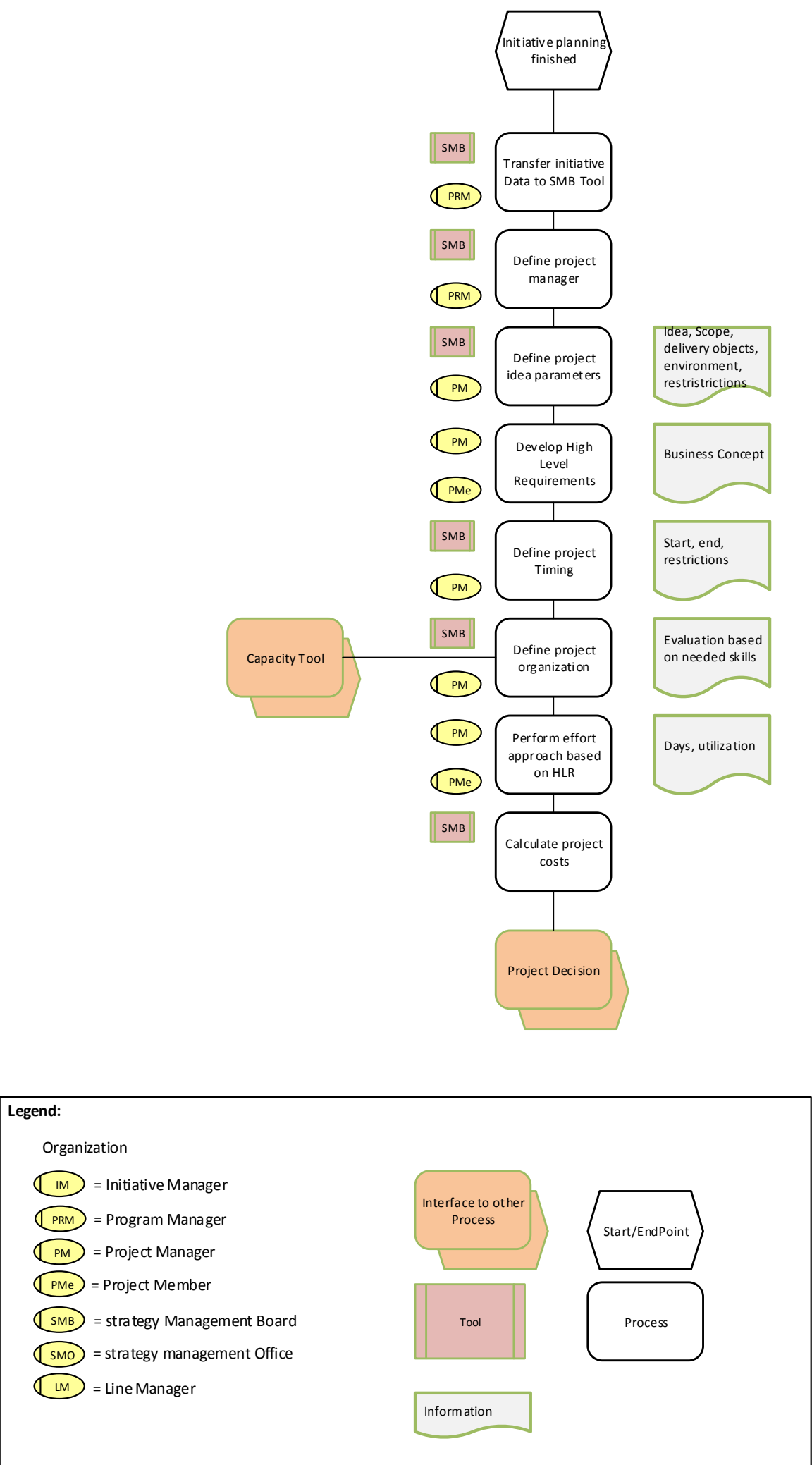

Figure 33: Process Project Idea evaluation 


\subsubsection{Step 2: Project Presentation and Decision}

The project presentation and decision step is probably the most important step of the execution phase. In this phase the project ideas were presented by the initiative or program leaders within the SMB Council and the decision will be made, which project will be performed in the future. Before the presentation the SMO is preparing the SMB Tool - project decision. This tool enables the Council to decide on an analytic basis and with the absolute scope to strategic goals. The decision step is the first of two processes in the SMB Council. The second is the project approval presented in chapter 5.7.4.

\subsubsection{Presentation}

The presentation of projects is based on the project evaluation sheet. All information and facts from the sheet are transformed into a slideshow template and presented to the SMB Council.

\subsubsection{Decision}

The decision process is a multi-step approach split into two main areas: Decision preparation performed by the SMO and decision making performed by the SMBOrg. Generally there are three main factors to consider for the decision:

1) Financial decision aspects as goal value, costs and benefits

2) Resource capacity

3) Time 


\subsection{Preparation: Calculate project Goals, Costs and Benefit}

The first step is to translate the action goals into project goals by calculation. The next step is to get all project costs information from the project evaluation sheets and last, calculate the project benefit, the strategic benefit, the total project goal and the total project costs as shown in the figure below.

\begin{tabular}{|c|c|c|c|c|c|}
\hline \multicolumn{2}{|c|}{ Strategic Actions } & \multicolumn{4}{|c|}{ Projects Goal/Costs } \\
\hline Action & Action Goal & Projects & Project Goal & Project Costs & $\begin{array}{c}\text { Project Benefit } \\
\text { (Total = strategic } \\
\text { benefit) }\end{array}$ \\
\hline Action 8 & $100.000,00 €$ & Project 1 & $100.000,00 €$ & $50.000,00 €$ & $50.000,00 €$ \\
\hline Action 7 & $300.000,00 €$ & \multirow{2}{*}{ Project 2} & \multirow{2}{*}{$306.000,00 €$} & \multirow{2}{*}{$37.210,39 €$} & \multirow{2}{*}{$268.789,61 €$} \\
\hline Action 12 & $6.000,00 €$ & & & & \\
\hline Action 13 & $4.000,00 €$ & Project 3 & $4.000,00 €$ & $3.750,00 €$ & $250,00 €$ \\
\hline Action 2 & $1.000 .000,00 €$ & \multirow{2}{*}{ Project 4} & \multirow{2}{*}{$2.000 .000,00 €$} & \multirow{2}{*}{$250.000,00 €$} & \multirow{2}{*}{$1.750 .000,00 €$} \\
\hline Action 3 & $1.000 .000,00 €$ & & & & \\
\hline Action 4 & $500.000,00 €$ & \multirow{3}{*}{ Project 5} & \multirow{3}{*}{$1.100 .000,00 €$} & \multirow{3}{*}{$100.000,00 €$} & \multirow{3}{*}{$1.000 .000,00 €$} \\
\hline Action 5 & $300.000,00 €$ & & & & \\
\hline Action 6 & $300.000,00 €$ & & & & \\
\hline Action 9 & $600.000,00 €$ & \multirow{4}{*}{ Project 6} & \multirow{4}{*}{$1.040 .000,00 €$} & \multirow{4}{*}{$850.000,00 €$} & \multirow{4}{*}{$190.000,00 €$} \\
\hline Action 10 & $400.000,00 €$ & & & & \\
\hline Action 11 & $30.000,00 €$ & & & & \\
\hline Action 14 & $10.000,00 €$ & & & & \\
\hline Action 1 & $2.500 .000,00 €$ & Project 7 & $2.500 .000,00 €$ & $2.250 .000,00 €$ & $250.000,00 €$ \\
\hline Total & $7.050 .000,00 €$ & Total & $7.050 .000,00 €$ & $3.540 .960,39 €$ & $3.509 .039,61 €$ \\
\hline
\end{tabular}

Table 18: SMB Tool Project Decision - Project Benefit Calculation 


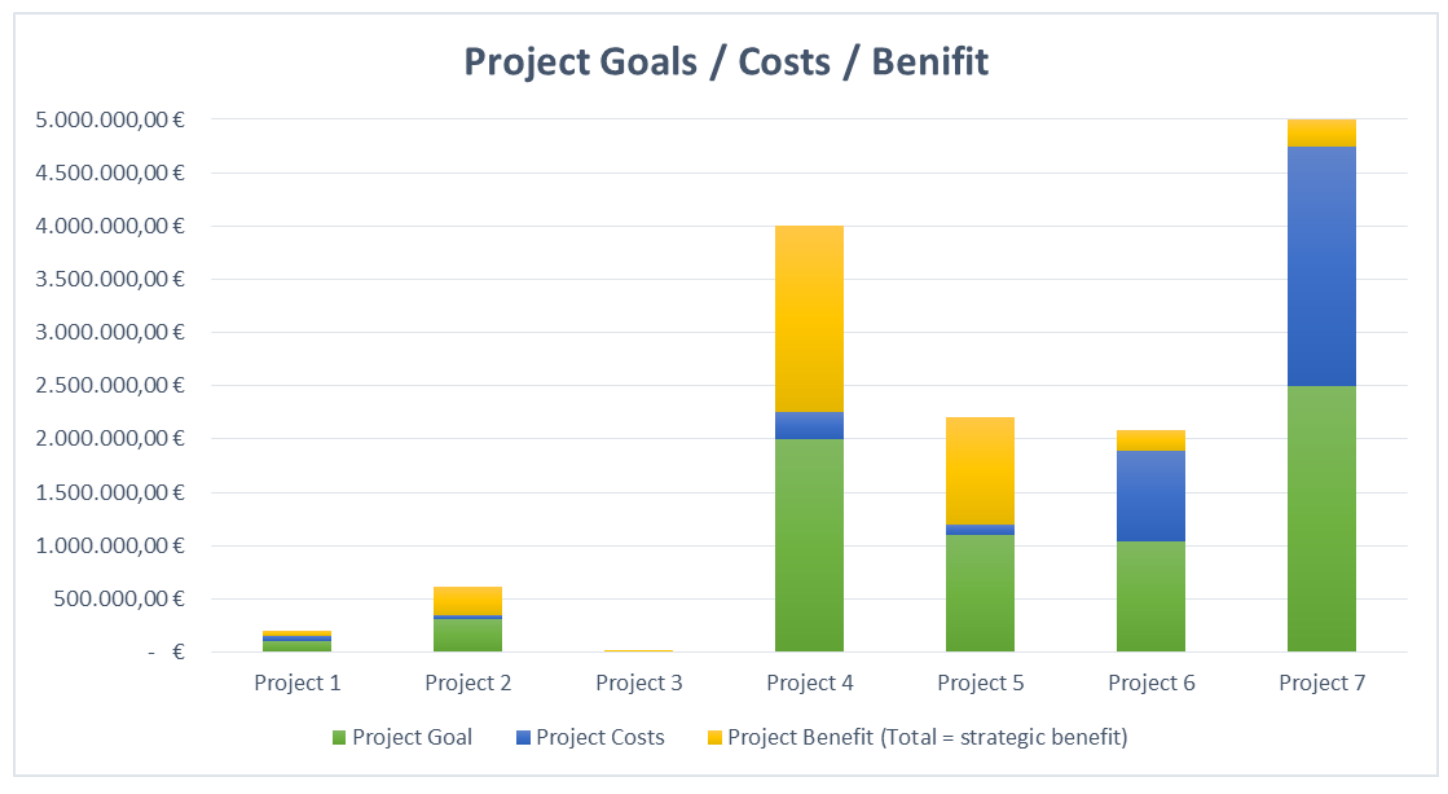

Figure 34: SMB Tool Project Decision - Project Benefit Graph

\subsection{Preparation: Calculate Project Contribution}

The next step is to calculate the project contribution in form of

a) Project goal contribution to total strategy goal

Ratio of single project goal to overall project goal (strategic goal)

b) Project benefit contribution to total strategic benefit.

Ratio of single project benefit to strategic benefit 


\begin{tabular}{|c|c|c|c|c|c|}
\hline Projects & Project Goal & Project Costs & $\begin{array}{l}\text { Project Benefit (Total } \\
=\text { strategic benefit) }\end{array}$ & $\begin{array}{c}\text { Project Goal } \\
\text { Contribution to } \\
\text { Total strategy } \\
\text { Goal }\end{array}$ & $\begin{array}{c}\text { Project } \\
\text { Benefit } \\
\text { Contribution } \\
\text { to Total } \\
\text { strategic } \\
\text { benefit }\end{array}$ \\
\hline Project 1 & $100.000,00 €$ & $50.000,00 €$ & $50.000,00 €$ & $1 \%$ & $1 \%$ \\
\hline Project 2 & $306.000,00 €$ & $37.210,39 €$ & $268.789,61 €$ & $4 \%$ & $8 \%$ \\
\hline Project 3 & $4.000,00 €$ & $3.750,00 €$ & $250,00 €$ & $0 \%$ & $0 \%$ \\
\hline Project 4 & $2.000 .000,00 €$ & $250.000,00 €$ & $1.750 .000,00 €$ & $28 \%$ & $50 \%$ \\
\hline Project 5 & $1.100 .000,00 €$ & $100.000,00 €$ & $1.000 .000,00 €$ & $16 \%$ & $28 \%$ \\
\hline Project 6 & $1.040 .000,00 €$ & $850.000,00 €$ & $190.000,00 €$ & $15 \%$ & $5 \%$ \\
\hline Project 7 & $2.500 .000,00 €$ & $2.250 .000,00 €$ & $250.000,00 €$ & $35 \%$ & $7 \%$ \\
\hline Total & $7.050 .000,00 €$ & $3.540 .960,39 €$ & $3.509 .039,61 €$ & & \\
\hline
\end{tabular}

Table 19: SMB Tool Project Decision - Project Contribution Calculation

\section{Preparation: Ranking of projects}

This step has the following three sub-steps:

1) Rank the projects by the factors project goal, project benefit, project goal contribution, project benefit contribution.

2) Define a rating factor for the four categories

3) Calculate the total ranking (Lowest Value = best ranked) 


\begin{tabular}{|c|c|c|c|c|c|c|c|c|c|}
\hline Projects & $\begin{array}{c}\text { Project } \\
\text { Goal }\end{array}$ & $\begin{array}{l}\text { Project } \\
\text { Benefit }\end{array}$ & $\begin{array}{l}\text { Projekt Goal } \\
\text { Contribution }\end{array}$ & $\begin{array}{c}\text { Projekt Benefit } \\
\text { Contribution }\end{array}$ & $\begin{array}{c}\text { Project } \\
\text { Goal }\end{array}$ & $\begin{array}{l}\text { Project } \\
\text { Benefit }\end{array}$ & $\begin{array}{l}\text { Projekt Goal } \\
\text { Contribution }\end{array}$ & $\begin{array}{c}\text { Projekt } \\
\text { Benefit } \\
\text { Contribution }\end{array}$ & $\begin{array}{c}\text { Rating with } \\
\text { Ranking }\end{array}$ \\
\hline Project 1 & 6 & 6 & 6 & 6 & 0,5 & 0,5 & 1 & 6 & 6,00 \\
\hline \multirow{2}{*}{ Project 2} & \multirow{2}{*}{5} & \multirow{2}{*}{3} & \multirow{2}{*}{5} & \multirow{2}{*}{3} & 0,5 & 0,5 & 1 & 6 & \multirow{2}{*}{3,38} \\
\hline & & & & & 0,5 & 0,5 & 1 & 6 & \\
\hline Project 3 & 7 & 7 & 7 & 7 & 0,5 & 0,5 & 1 & 6 & 7,00 \\
\hline \multirow{2}{*}{ Project 4} & \multirow{2}{*}{2} & \multirow{2}{*}{1} & \multirow{2}{*}{2} & \multirow{2}{*}{1} & 0,5 & 0,5 & 1 & 6 & \multirow{2}{*}{1,19} \\
\hline & & & & & 0,5 & 0,5 & 1 & 6 & \\
\hline \multirow{3}{*}{ Project 5} & \multirow{3}{*}{3} & \multirow{3}{*}{2} & \multirow{3}{*}{3} & \multirow{3}{*}{2} & 0,5 & 0,5 & 1 & 6 & \multirow{3}{*}{2,19} \\
\hline & & & & & 0,5 & 0,5 & 1 & 6 & \\
\hline & & & & & 0,5 & 0,5 & 1 & 6 & \\
\hline \multirow{4}{*}{ Project 6} & \multirow{4}{*}{4} & \multirow{4}{*}{5} & \multirow{4}{*}{4} & \multirow{4}{*}{5} & 0,5 & 0,5 & 1 & 6 & \multirow{4}{*}{4,81} \\
\hline & & & & & 0,5 & 0,5 & 1 & 6 & \\
\hline & & & & & 0,5 & 0,5 & 1 & 6 & \\
\hline & & & & & 0,5 & 0,5 & 1 & 6 & \\
\hline Project 7 & 1 & 4 & 1 & 4 & 0,5 & 0,5 & 1 & 6 & 3,44 \\
\hline
\end{tabular}

Table 20: SMB Tool Project Decision - Project Ranking - Calculation

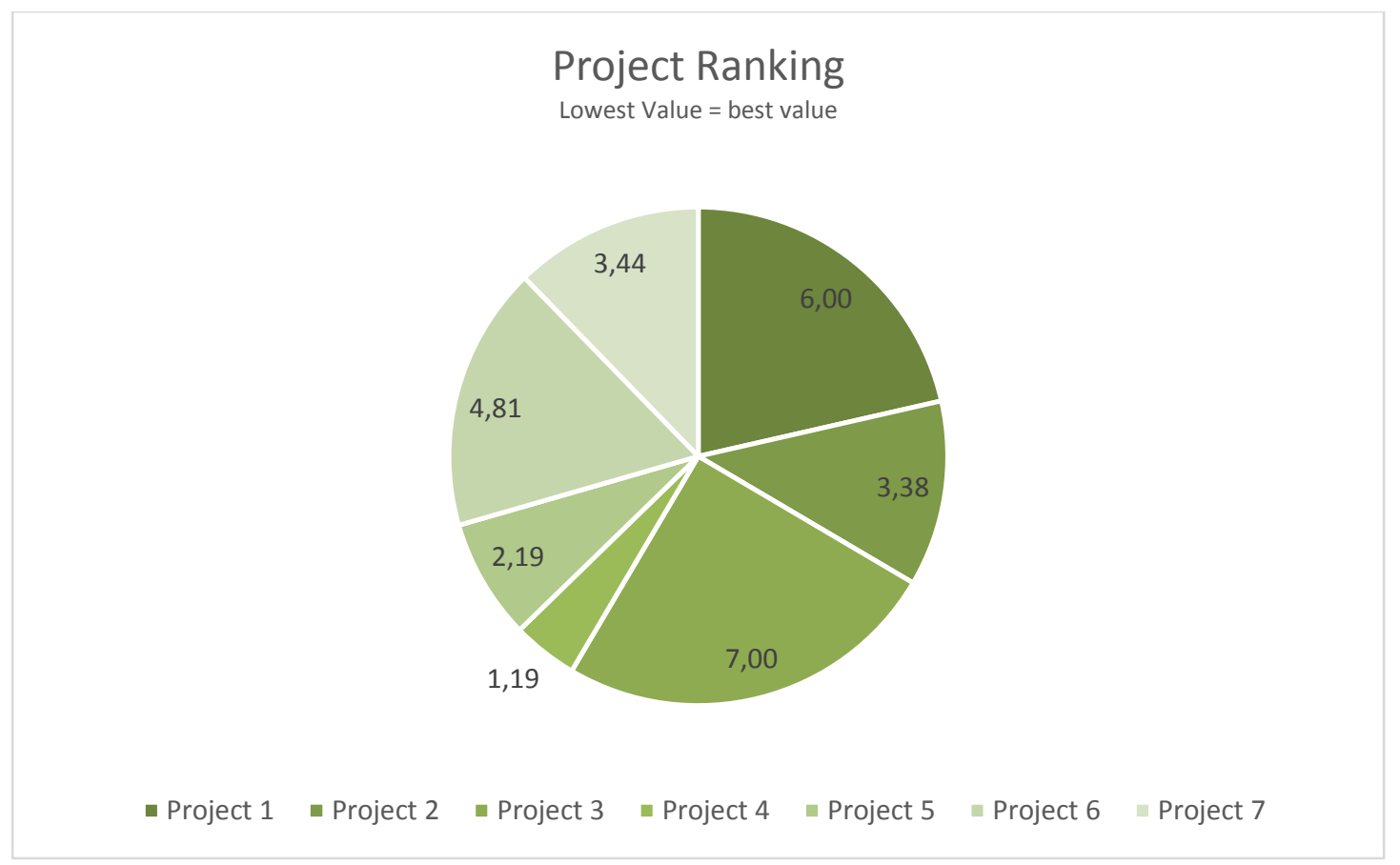

Figure 35: SMB Tool Project Decision - Project Ranking - Graph 


\subsection{Preparation: Calculate Project Time}

The calculation of the project time is based on the project idea evaluation sheet start and end date and if necessary on restriction regarding the two times (e.g. needed end date because of environmental facts like exhibition dates). The days are calculated with respect of weekends and public holidays.

\begin{tabular}{|c|c|c|c|}
\hline Projects & Start Date & End Date & Days \\
\hline Project 1 & 01.06 .2014 & 01.12 .2014 & 131 \\
\hline Project 2 & 01.01 .2014 & 01.03 .2014 & 42 \\
\hline Project 3 & 01.06 .2014 & 01.12 .2014 & 131 \\
\hline Project 4 & 01.01 .2014 & 01.12 .2014 & 239 \\
\hline Project 5 & 01.01 .2014 & 01.06 .2014 & 108 \\
\hline Project 6 & 01.01 .2014 & 01.12 .2014 & 239 \\
\hline Project 7 & 01.01 .2014 & 01.01 .2015 & 261 \\
\hline
\end{tabular}

Table 21: SMB Tool Project Decision - Project Time Calculation

\section{Project Runtime}

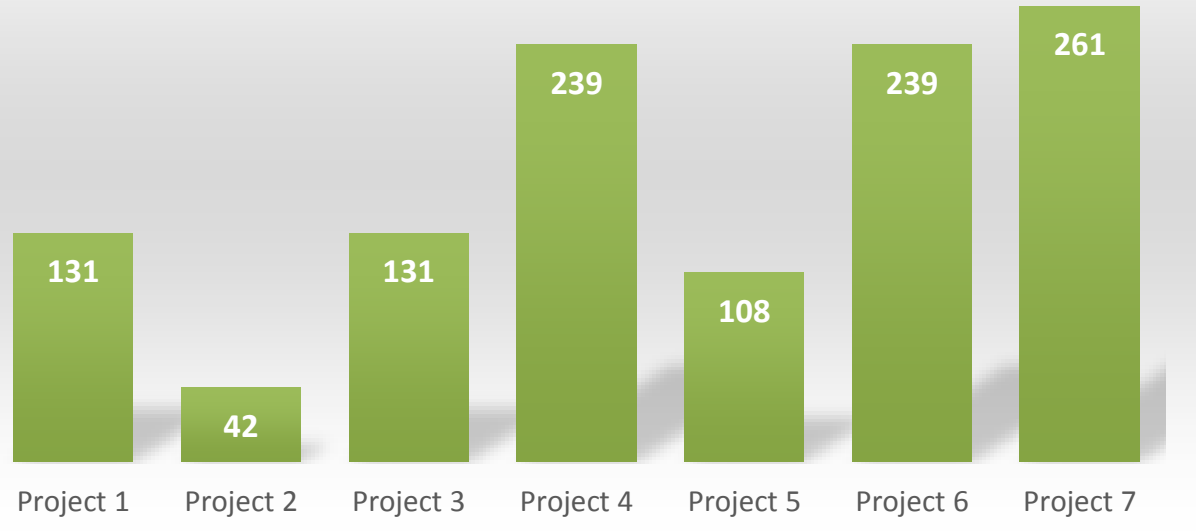

Figure 36: SMB Tool Project Decision - Project Time Graph 


\subsection{Preparation: Calculate Resource Utilization}

The basis for the calculation of the resources and their utilization are the project evaluation sheets. The planned resources based on the business concept and their project specific utilization are connected to the data from the capacity tool where line activity utilization is stored to get an overview of the overall utilization per person as shown in the table and figure below.

\begin{tabular}{|c|c|c|c|c|c|c|c|c|c|c|c|}
\hline \multicolumn{3}{|c|}{ Ressources } & \multicolumn{7}{|c|}{ Project utilization for project time } & \multirow{2}{*}{\begin{tabular}{|c|}
$\begin{array}{c}\text { Line } \\
\text { utilization }\end{array}$ \\
Line \\
\end{tabular}} & \multirow{2}{*}{$\begin{array}{c}\begin{array}{c}\text { TOTAL } \\
\text { utilization }\end{array} \\
\text { Total }\end{array}$} \\
\hline Name & Org. Unit & ISOL-M skills & P1 & $\mathrm{P} 2$ & P3 & P4 & P5 & P6 & P7 & & \\
\hline Person 1 & Unit 1 & program manager & $20 \%$ & $20 \%$ & $10 \%$ & $20 \%$ & $10 \%$ & $10 \%$ & $20 \%$ & $0 \%$ & $110 \%$ \\
\hline Person 2 & Unit 2 & initiative manager & $5 \%$ & $5 \%$ & $10 \%$ & $25 \%$ & $20 \%$ & $25 \%$ & $20 \%$ & $0 \%$ & $110 \%$ \\
\hline Person 3 & Unit 3 & OSM manager & $25 \%$ & $10 \%$ & $10 \%$ & $10 \%$ & $60 \%$ & $10 \%$ & $25 \%$ & $0 \%$ & $150 \%$ \\
\hline Person 4 & Unit 4 & project manager & $30 \%$ & $30 \%$ & $30 \%$ & $0 \%$ & $0 \%$ & $0 \%$ & $30 \%$ & $0 \%$ & $120 \%$ \\
\hline Person 5 & Unit 5 & project member & $30 \%$ & $50 \%$ & $0 \%$ & $0 \%$ & $0 \%$ & $0 \%$ & $0 \%$ & $50 \%$ & $130 \%$ \\
\hline Person 6 & Unit 6 & project member & $30 \%$ & $30 \%$ & $0 \%$ & $0 \%$ & $50 \%$ & $0 \%$ & $0 \%$ & $30 \%$ & $140 \%$ \\
\hline \begin{tabular}{|l|} 
Person 7 \\
\end{tabular} & Unit 7 & project member & $10 \%$ & $0 \%$ & $10 \%$ & $0 \%$ & $0 \%$ & $0 \%$ & $0 \%$ & $20 \%$ & $40 \%$ \\
\hline Person 8 & Unit 8 & project member & $20 \%$ & $0 \%$ & $0 \%$ & \begin{tabular}{l|l}
$0 \%$ \\
\end{tabular} & $50 \%$ & $0 \%$ & $0 \%$ & $30 \%$ & $100 \%$ \\
\hline Person 9 & Unit 9 & project member & $0 \%$ & $0 \%$ & $0 \%$ & $0 \%$ & $70 \%$ & $0 \%$ & $25 \%$ & $40 \%$ & $135 \%$ \\
\hline Person 10 & Unit 10 & project member & $0 \%$ & $0 \%$ & $40 \%$ & \begin{tabular}{l|l}
$0 \%$ \\
\end{tabular} & $10 \%$ & $0 \%$ & $80 \%$ & $0 \%$ & $130 \%$ \\
\hline
\end{tabular}

\section{Resource Utilization}

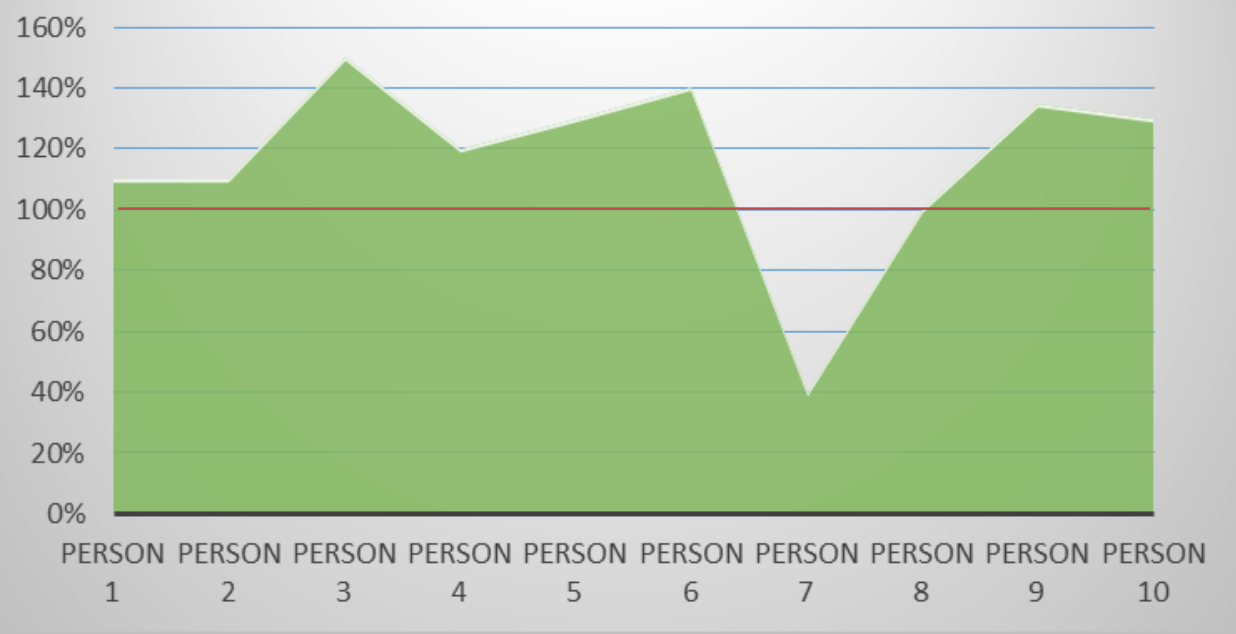

Figure 37: SMB Tool Project Decision - Project Resource Utilization Calculation

Problem with this first approach is, that the total utilization is without respect to the project timelines. For that reason a project-person based monthly resource 
utilization calculation needs to be done as shown in the tables below. The project time calculation is the basis for the monthly calculation.

\begin{tabular}{|c|c|c|c|c|c|c|c|}
\hline \multicolumn{7}{|c|}{ Project Activity Index per Month } \\
\hline Month & Project 1 & Project 2 & Project 3 & Project 4 & Project 5 & Project 6 & Project 7 \\
\hline 1 & & 1 & & 1 & 1 & 1 & 1 \\
\hline 2 & & 1 & & 1 & 1 & 1 & 1 \\
\hline 3 & & & & 1 & 1 & 1 & 1 \\
\hline 4 & & & & 1 & 1 & 1 & 1 \\
\hline 5 & & & & 1 & 1 & 1 & 1 \\
\hline 6 & 1 & & 1 & 1 & & 1 & 1 \\
\hline 7 & 1 & & 1 & 1 & & 1 & 1 \\
\hline 8 & 1 & & 1 & 1 & & 1 & 1 \\
\hline 9 & 1 & & 1 & 1 & & 1 & 1 \\
\hline 10 & 1 & & 1 & 1 & & 1 & 1 \\
\hline 11 & 1 & & 1 & 1 & & 1 & 1 \\
\hline 12 & & & & & & & 1 \\
\hline
\end{tabular}

Table 23: SMB Tool Project Decision - Project Activity Index per Month

\begin{tabular}{|c|c|c|c|c|c|c|c|c|c|c|}
\hline Person 2 & \multicolumn{10}{|c|}{ Person Activity Index } \\
\hline M & Project 1 & Project 2 & Project 3 & Project 4 & Project 5 & Project 6 & Project 7 & Total P & Total Line & Total \\
\hline 1 & $0 \%$ & $5 \%$ & $0 \%$ & $25 \%$ & $20 \%$ & $25 \%$ & $20 \%$ & $95 \%$ & $0 \%$ & $95 \%$ \\
\hline 2 & $0 \%$ & $5 \%$ & $0 \%$ & $25 \%$ & $20 \%$ & $25 \%$ & $20 \%$ & $95 \%$ & $0 \%$ & $95 \%$ \\
\hline 3 & $0 \%$ & $0 \%$ & $0 \%$ & $25 \%$ & $20 \%$ & $25 \%$ & $20 \%$ & $90 \%$ & $0 \%$ & $90 \%$ \\
\hline 4 & $0 \%$ & $0 \%$ & $0 \%$ & $25 \%$ & $20 \%$ & $25 \%$ & $20 \%$ & $90 \%$ & $0 \%$ & $90 \%$ \\
\hline 5 & $0 \%$ & $0 \%$ & $0 \%$ & $25 \%$ & $20 \%$ & $25 \%$ & $20 \%$ & $90 \%$ & $0 \%$ & $90 \%$ \\
\hline 6 & $5 \%$ & $0 \%$ & $10 \%$ & $25 \%$ & $0 \%$ & $25 \%$ & $20 \%$ & $85 \%$ & $0 \%$ & $85 \%$ \\
\hline 7 & $5 \%$ & $0 \%$ & $10 \%$ & $25 \%$ & $0 \%$ & $25 \%$ & $20 \%$ & $85 \%$ & $0 \%$ & $85 \%$ \\
\hline 8 & $5 \%$ & $0 \%$ & $10 \%$ & $25 \%$ & $0 \%$ & $25 \%$ & $20 \%$ & $85 \%$ & $0 \%$ & $85 \%$ \\
\hline 9 & $5 \%$ & $0 \%$ & $10 \%$ & $25 \%$ & $0 \%$ & $25 \%$ & $20 \%$ & $85 \%$ & $0 \%$ & $85 \%$ \\
\hline 10 & $5 \%$ & $0 \%$ & $10 \%$ & $25 \%$ & $0 \%$ & $25 \%$ & $20 \%$ & $85 \%$ & $0 \%$ & $85 \%$ \\
\hline 11 & $5 \%$ & $0 \%$ & $10 \%$ & $25 \%$ & $0 \%$ & $25 \%$ & $20 \%$ & $85 \%$ & $0 \%$ & $85 \%$ \\
\hline 12 & $0 \%$ & $0 \%$ & $0 \%$ & $0 \%$ & $0 \%$ & $0 \%$ & $20 \%$ & $20 \%$ & $0 \%$ & $20 \%$ \\
\hline
\end{tabular}




\begin{tabular}{|c|c|c|c|c|c|c|c|c|c|c|}
\hline Person 3 & \multicolumn{10}{|c|}{ Person Activity Index } \\
\hline Month & Project 1 & Project 2 & Project 3 & Project 4 & Project 5 & Project 6 & Project 7 & Total P & Total Line & Total \\
\hline 1 & $0 \%$ & $10 \%$ & $0 \%$ & $10 \%$ & $60 \%$ & $10 \%$ & $25 \%$ & $115 \%$ & $0 \%$ & $115 \%$ \\
\hline 2 & $0 \%$ & $10 \%$ & $0 \%$ & $10 \%$ & $60 \%$ & $10 \%$ & $25 \%$ & $115 \%$ & $0 \%$ & $115 \%$ \\
\hline 3 & $0 \%$ & $0 \%$ & $0 \%$ & $10 \%$ & $60 \%$ & $10 \%$ & $25 \%$ & $105 \%$ & $0 \%$ & $105 \%$ \\
\hline 4 & $0 \%$ & $0 \%$ & $0 \%$ & $10 \%$ & $60 \%$ & $10 \%$ & $25 \%$ & $105 \%$ & $0 \%$ & $105 \%$ \\
\hline 5 & $0 \%$ & $0 \%$ & $0 \%$ & $10 \%$ & $60 \%$ & $10 \%$ & $25 \%$ & $105 \%$ & $0 \%$ & $105 \%$ \\
\hline 6 & $25 \%$ & $0 \%$ & $10 \%$ & $10 \%$ & $0 \%$ & $10 \%$ & $25 \%$ & $80 \%$ & $0 \%$ & $80 \%$ \\
\hline 7 & $25 \%$ & $0 \%$ & $10 \%$ & $10 \%$ & $0 \%$ & $10 \%$ & $25 \%$ & $80 \%$ & $0 \%$ & $80 \%$ \\
\hline 8 & $25 \%$ & $0 \%$ & $10 \%$ & $10 \%$ & $0 \%$ & $10 \%$ & $25 \%$ & $80 \%$ & $0 \%$ & $80 \%$ \\
\hline 9 & $25 \%$ & $0 \%$ & $10 \%$ & $10 \%$ & $0 \%$ & $10 \%$ & $25 \%$ & $80 \%$ & $0 \%$ & $80 \%$ \\
\hline 10 & $25 \%$ & $0 \%$ & $10 \%$ & $10 \%$ & $0 \%$ & $10 \%$ & $25 \%$ & $80 \%$ & $0 \%$ & $80 \%$ \\
\hline 11 & $25 \%$ & $0 \%$ & $10 \%$ & $10 \%$ & $0 \%$ & $10 \%$ & $25 \%$ & $80 \%$ & $0 \%$ & $80 \%$ \\
\hline 12 & $0 \%$ & $0 \%$ & $0 \%$ & $0 \%$ & $0 \%$ & $0 \%$ & $25 \%$ & $25 \%$ & $0 \%$ & $25 \%$ \\
\hline
\end{tabular}

Table 24: SMB Tool Project Decision - Person Activity Index

The calculation from Table 22 shows a value for person 2 of $110 \%$ and for person 3 a value of $150 \%$ of utilization.

With the deeper look at the distribution over the months, person 2 has no excessive value and person 3 only in the first 5 month.

Summarized these 5 steps need to be done for every project based on the evaluation sheets for the preparation of the decision in the SMB Council:

1) Calculate project goals, costs and benefits

2) Calculate project contribution to strategic goals

3) Rank the project by financial aspects

4) Calculate project time

5) Calculate resource utilization 


\subsection{Decision Making: Decision Process}

With this preparation the SMB Council can be performed. The lead of the SMB Council is with the SMO. After the presentation of the project as described, the SMO presents the preparation results and helps the board with the following decision process to make the decision.

As already stated the three main decision factors are:

1) Financial Decision Aspects as Goal value, costs and benefits

2) Resource capacity

3) Time

Based on this and the information from the preparation phase the following decision process can be set.

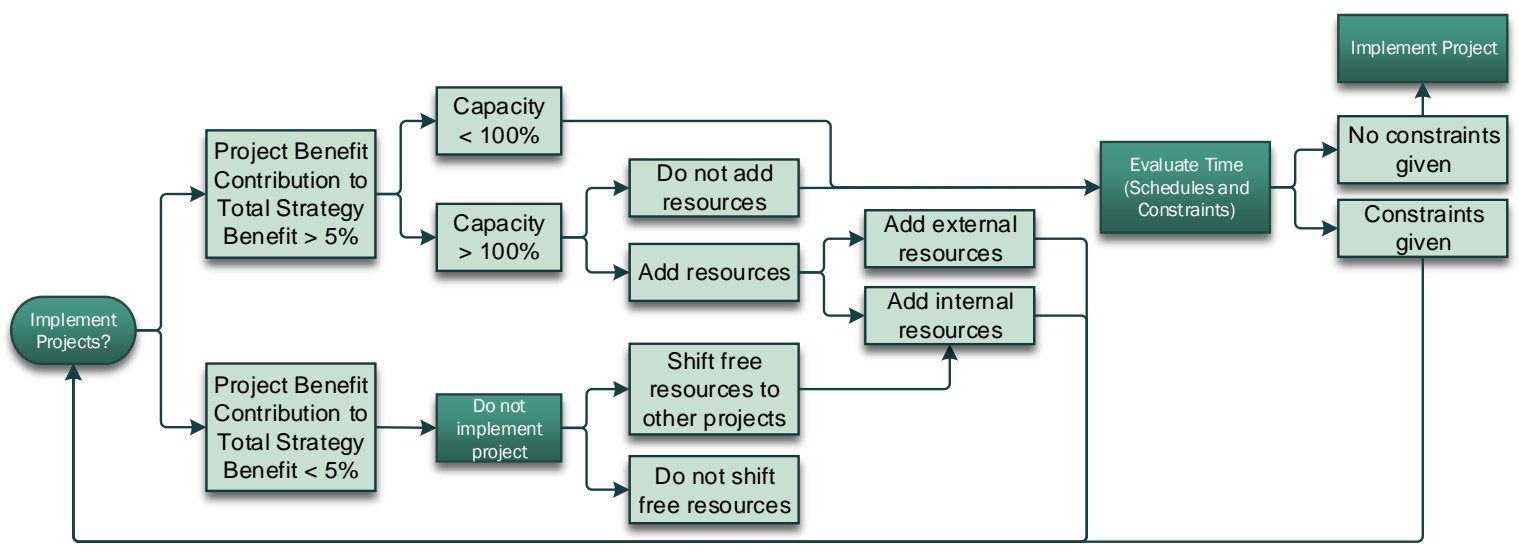

Figure 38: Project decision - decision process 


\subsection{Decision Factor: Financial Values}

The first factor for the decision is the financial value of the project and therefor a decision framework needs to be defined like for example all projects with a project benefit contribution lower than 5\% will not be performed. Many companies define this value based on the internal corporate interest value. Other companies define the framework with respect to other calculated values. However this framework is set, if there are any projects which can be eliminated by this step, all preparation calculation steps need to be redone. The SMB Tool provides an easy and on demand solution for that recalculation in real-time in the SMB Council.

\subsection{Decision Factor: Resource capacity \& Project timelines}

Next step is to check if the left over projects generate any resource overbookings. If not every project can be delivered to the next ISOL-M step. If there are any overbookings the following simulations can be performed within the tool:

a) Is there the possibility of adding resources (e.g. external) to the projects? If yes, recalculate the financial aspects of the project. If no:

b) Are we able to shift resources from other projects? A shifting approach could be the ranking values. Rank resources from lower ranked project to higher ranked projects. If yes, recalculate the financial aspects of the project and don't approve lower ranked projects, if not:

c) Can we extend or change the time schedules of the projects to eliminate the resource overbookings with respect to possible time restrictions on projects? If yes, recalculate financial aspects and resource utilization. If not don't approve projects. 


\subsubsection{Step 3: Project Requirements}

The requirements for a project with respect to ITPM regulations are documented in three main documents shown in the below figure.

\section{Phase 4.3.: Requirements}

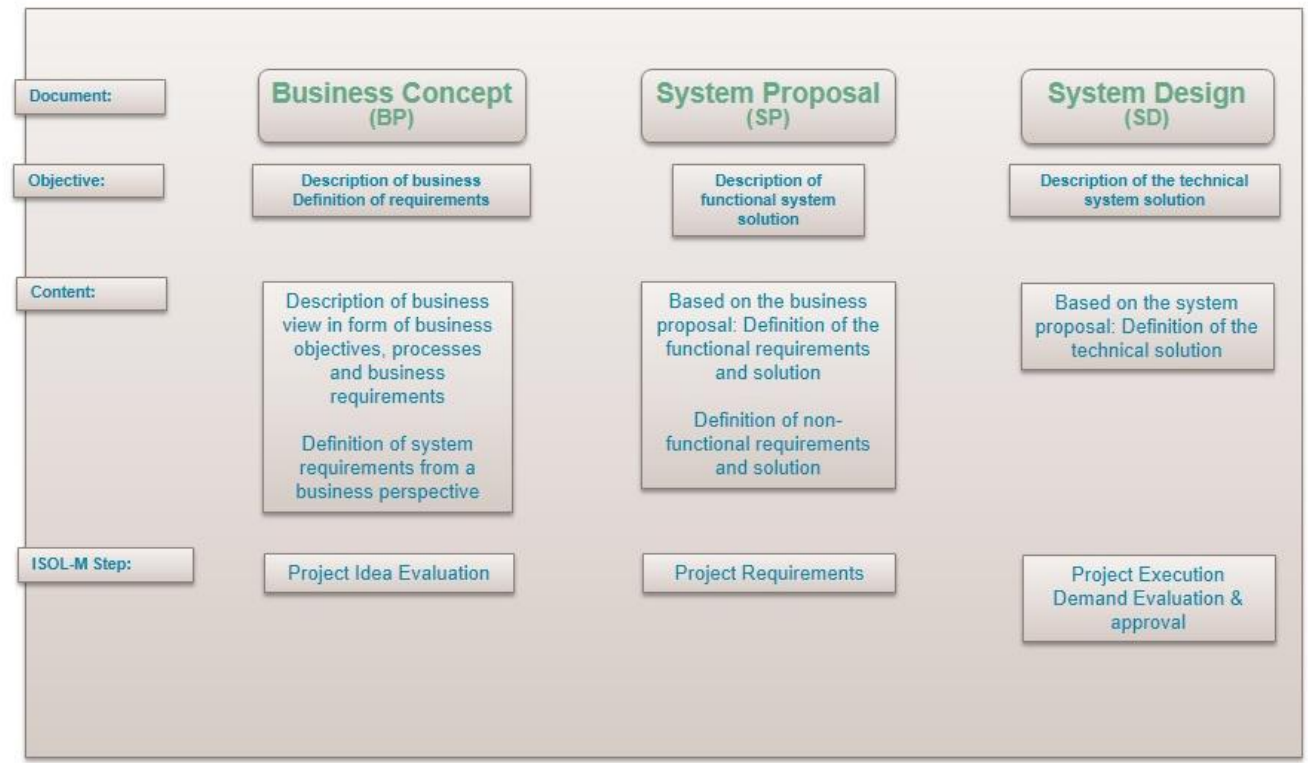

Figure 39: project requirements

The business concept is the first step in the requirement approach. It contains the business objectives, processes and requirements for the project for the realization of the strategic goals within the project. It is the basis for the first cost and resource effort approach for the project idea evaluation and the basis for the project decision.

The system proposal defines the functional and non-functional requirements for the project. It is the main focus of the step 3: project requirements. It is a detailed view and documentation of the requirements from the business concept and the basis for the final cost and effort approach. The results of this approach are transferred to the SMB decision tool and on that basis the final approval of the project will be performed in the SMB Council in the step project approval.

Responsibility for the management of the development of these documents and the management of the described processes is dedicated to the project manager. 


\subsubsection{Step 4: Project Approval}

The step 4 project approval is the second process of the SMB Council. After the project decision the detailed requirements of the project are developed within the system proposal.

The concretion of the assumptions of the business concept normally conduct to changes in form of

- Needed resources

- Changes in the timeline

- Changes in the project goal (strategic revenue the project can perform in the future).

All these changes need to be communicated from the project leader who is responsible for the project requirement phase to the SMO. The SMO prepares the second part of the SMB Council the same way they do it within the project decision step with one additional step: calculate the GAP's between status "project decision" and "project approval" for an overview how the information from the requirement phase changes the decision factors.

After that the same procedure in the SMB Council takes place as with project decision.

\subsubsection{Step 5: Project Execution}

The design of the project execution step is based on GPM / ITPM Standards. Many companies have developed their own model for project management and project execution based on these standards. The main focus of this step is to show the defined 
best-practice approaches and interlink them with the ISOL-M dedicated to Kaplan's phases test, adapt and learn.

\subsubsection{Step 5.1.: Setup \& Planning}

The main focus of the project setup is to get a stabile fundament interconnected with the ISOL-M for the upcoming project. All processes within this step are performed with the project tool and the organizational responsibility is in the POrg, especially driven by the project manager, and with the project tool.

The first step of the project setup is the definition of the project phases and its delivery objects. As below figure shows the generic concept provides eight project phases with their delivery objects.

\section{Phase 4: Project Setup}

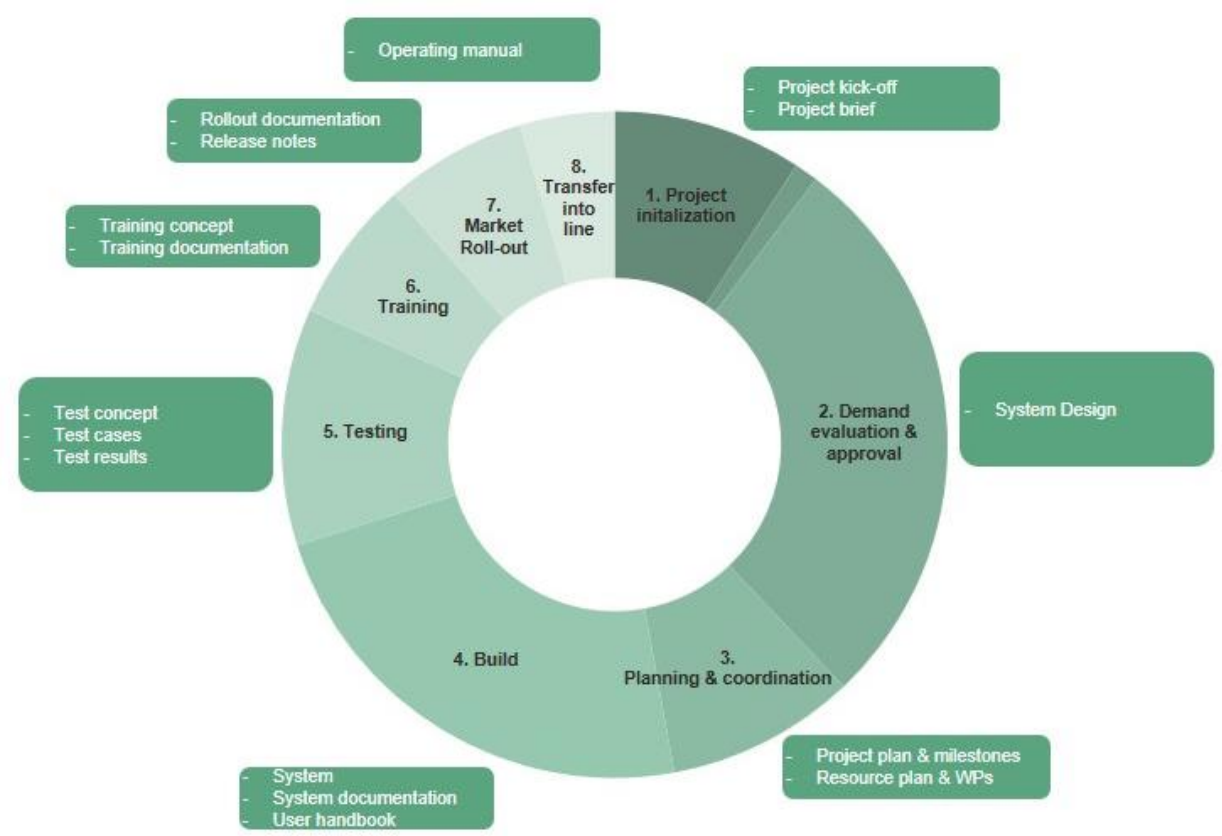

Figure 40: Project Setup 


\subsection{Project Initialization}

The project initialization step has two main delivery objects. First the project brief and second the project kick-off.

The project brief is an advancement of the project idea evaluation sheet. It provided all needed information about the project and its environment. The development of the project brief is within the responsibility of the project manager and needs to be approved by the project steering board. Typical content of the project brief should be:

- Project background

- Objectives

- Requirements

- Scope

- Approach

- Constraints and Assumptions and Risks

- Alternative solutions

- Profitability / project justification

- Costs, benefits (quality, quantity):

- Project organization

The second delivery object is the project kickoff. The Kickoff is a meeting of all project member with the project manager to start the project. The main focus of the kickoff meeting are:

- Presentation of the project brief

- Presentation of the project organization 
- Presentation of the project processes (Phase model, project collaboration model)

- Presentation of project tools
List of open issues
○ Project status
○ Risk register
Project plan

- Presentation of milestone plan (First timing approach for the project)

\subsection{Demand evaluation and approval}

The demand evaluation and approval step has a main goal: the development of the system design. The system design describes the solution for the requirements coming from the business concept and system proposal.

\section{Phase 4.5.1.2: Demand evaluation \& approval}

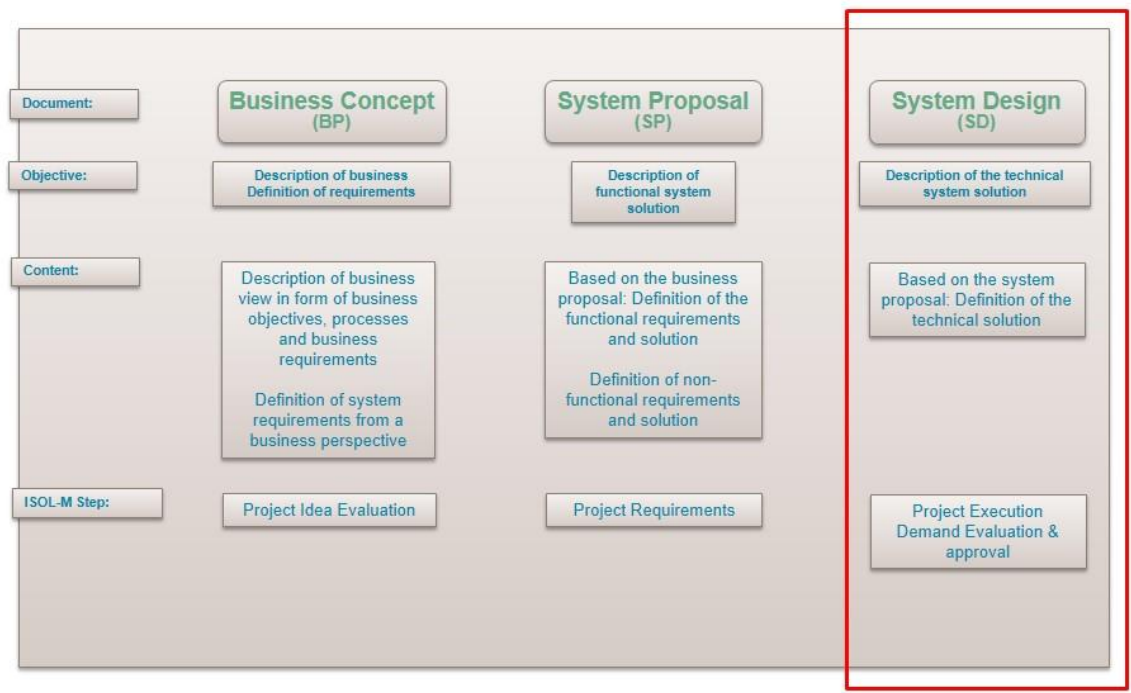

Figure 41: Demand evaluation and approval 


\subsection{Planning and coordination}

The planning step is also in the responsibility of the project manager. Input for this phase are the approved costs, resources and timelines from the project approval phase. Within this restrictions the planning of the project in form of a project plan, connected resource plan and cost plan needs to be performed. There are several standard tools (e.G. Microsoft Project) for technical support of these processes. An example is provided in the below figure. 


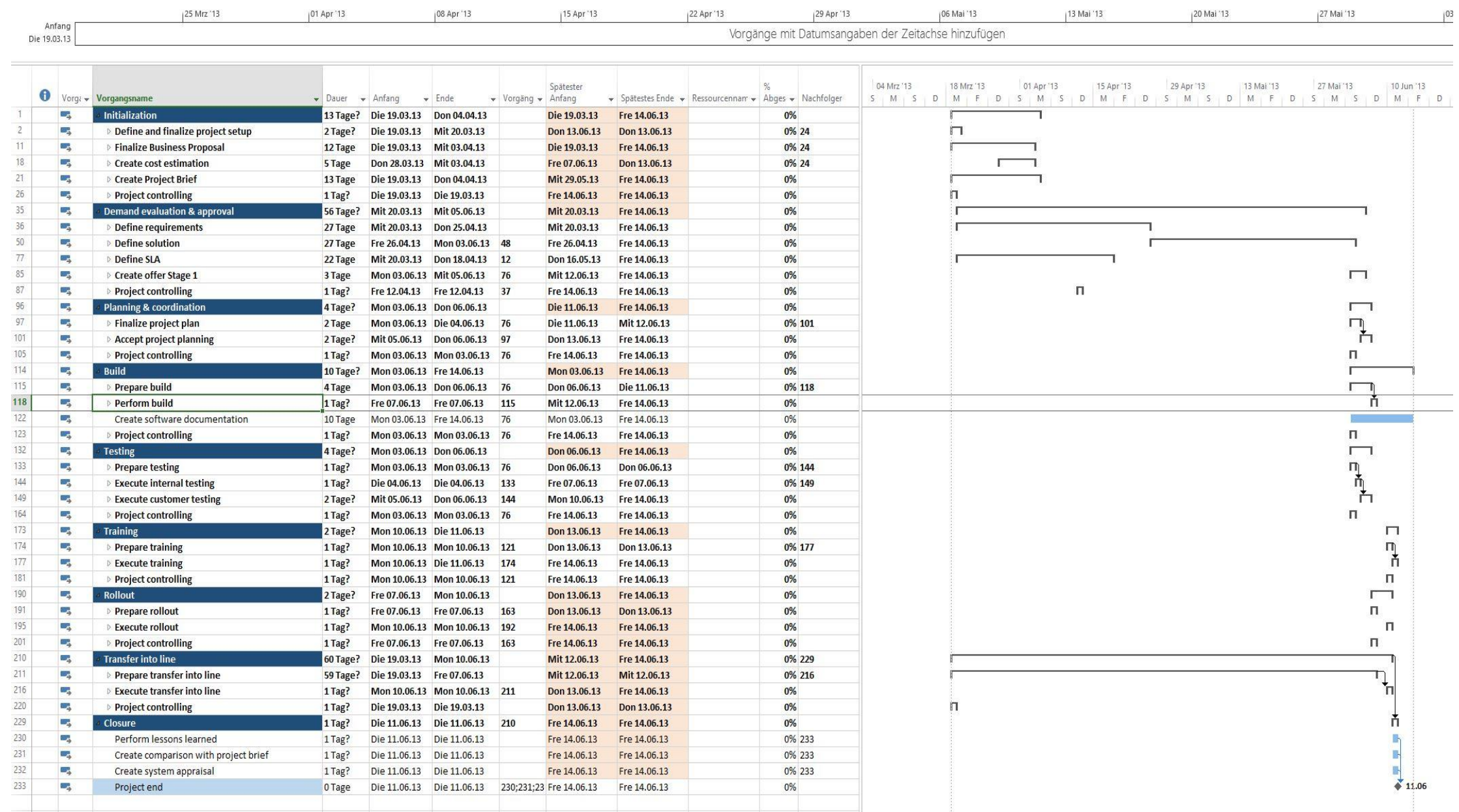

Figure 42: example generic project plan 
The coordination and control step is needed for the complete phase of project execution (planning, build, test, train, rollout and transfer into line). Main focus of the coordination and control step is to manage the project with respect to the three dimensions of a project: quality, time and costs. The project tool provides a template for that issue: the status report. The status report (Figure 43) has two main functions.

First to coordinate and control the activities (work packages, sub-work packages) within the project. Second to provide the needed information for the SMB tool.

\section{Phase 4.5.1.3: Planning and Coordination}

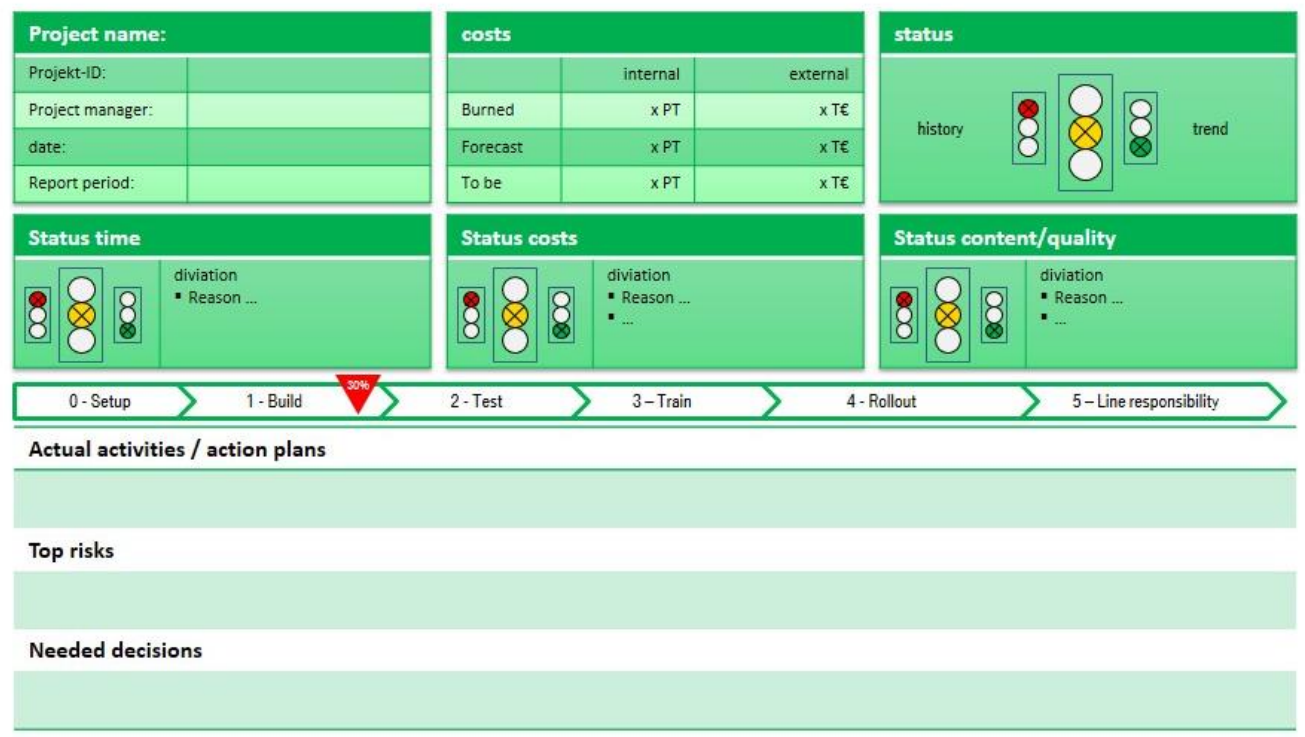

Figure 43: status report

The SMBOrg controls all initiatives, programs and projects in the SMB-Council. There need to be a standardized communication line between the status report of a project and the SMB Tool by importing the needed information:

- Status of the project by status light per project dimension

- Changes to costs, quality of timeline 
This interconnection between operations (project) and strategy (SMBOrg) provides the possibility to manage strategic projects with full control. Within the SMB Council all project status are reported to the SMB Tool (control) and decisions about possible needed changes are done based on the SMB decision tool by recalculating the decision matrix. After that possible impacts to STRATEX and the capacity resource tool are automatically transmitted. 


\begin{tabular}{|c|c|c|c|c|c|c|c|c|c|c|c|c|c|c|}
\hline \multicolumn{3}{|c|}{ Project } & \multicolumn{4}{|c|}{ Status } & \multicolumn{3}{|c|}{ Progress } & \multicolumn{3}{|c|}{ Change needed } & \multicolumn{2}{|c|}{ SMB Approval } \\
\hline Projects & Value/Ratio & $\begin{array}{c}\text { Costs per } \\
\text { project }\end{array}$ & $\begin{array}{l}\text { Quality status } \\
\text { Quality trend } \\
\text { Quality history }\end{array}$ & $\begin{array}{l}\text { Time status } \\
\text { Time trend } \\
\text { Time history }\end{array}$ & $\begin{array}{l}\text { Costs status } \\
\text { Costs trend } \\
\text { Costs history }\end{array}$ & Overall & Quality & Time & Costs & Quality & Time & Costs & Decision & Result \\
\hline Project 1 & $100.000,00 €$ & $50.000,00 €$ & $\begin{array}{lll} & \bigcirc & 0 \\
0 & \bigcirc & 0 \\
0 & 0 & 0\end{array}$ & $\begin{array}{lll}0 & \bigcirc & 0 \\
0 & 0 & 0 \\
0 & 0 & 0\end{array}$ & $\begin{array}{lll}0 & 0 & 0 \\
0 & 0 & 0 \\
0 & 0 & 0\end{array}$ & on track & $60 \%$ & $40 \%$ & $50 \%$ & none & none & none & yes/no & $\begin{array}{l}\text { if yes - change } \\
\text { STRATEX } \\
\text { and/or } \\
\text { ressource } \\
\text { capacity } \\
\text { planning } \\
\end{array}$ \\
\hline Project 2 & $306.000,00 €$ & $37.210,39 €$ & $\begin{array}{lll}0 & \bigcirc & 0 \\
0 & \bigcirc & 0 \\
0 & 0 & 0\end{array}$ & $\begin{array}{lll}0 & 0 & 0 \\
0 & 0 & 0 \\
0 & 0 & C\end{array}$ & $\begin{array}{lll}0 & 0 & 0 \\
0 & 0 & 0 \\
0 & 0 & 0\end{array}$ & escalation time & $60 \%$ & $20 \%$ & $50 \%$ & none & $\begin{array}{c}\text { extend 3 } \\
\text { weeks }\end{array}$ & none & yes/no & $\begin{array}{l}\text { if yes - change } \\
\text { STRATEX } \\
\text { and/or } \\
\text { ressource } \\
\text { capacity } \\
\text { planning } \\
\end{array}$ \\
\hline Project 3 & $4.000,00 €$ & $3.750,00 €$ & $\begin{array}{lll}0 & \bigcirc & 0 \\
0 & 0 & 0 \\
0 & 0 & 0\end{array}$ & $\begin{array}{ll}0 & 0 \\
0 & 0 \\
0 & 0\end{array}$ & $\begin{array}{l}0 \\
0\end{array}$ & escalation costs & $60 \%$ & $40 \%$ & $80 \%$ & none & none & $\begin{array}{c}25000 \text { Euro } \\
\text { external } \\
\text { supplier }\end{array}$ & yes/no & $\begin{array}{l}\text { if yes - change } \\
\text { STRATEX } \\
\text { and/or } \\
\text { ressource } \\
\text { capacity } \\
\text { planning }\end{array}$ \\
\hline Project 4 & $2.000 .000,00 €$ & $250.000,00 €$ & $\begin{array}{lll}0 & \bigcirc & 0 \\
0 & 0 & 0 \\
0 & 0 & 0\end{array}$ & $\begin{array}{l}0 \\
0 \\
0\end{array}$ & $\begin{array}{ll}0 & 0 \\
0 & 0 \\
0 & 0\end{array}$ & on track & $60 \%$ & $40 \%$ & $50 \%$ & none & none & none & yes/no & $\begin{array}{l}\text { if yes - change } \\
\text { STRATEX } \\
\text { and/or } \\
\text { ressource } \\
\text { capacity } \\
\text { planning }\end{array}$ \\
\hline Project 5 & $1.100 .000,00 €$ & $100.000,00 €$ & $\begin{array}{lll}0 & \bigcirc & 0 \\
0 & \bigcirc & 0 \\
0 & 0 & 0\end{array}$ & $\begin{array}{ll}0 & 0 \\
0 & 0 \\
0 & 0\end{array}$ & $\begin{array}{lll}0 & 0 & 0 \\
0 & 0 & 0 \\
0 & 0 & 0\end{array}$ & on track & $60 \%$ & $40 \%$ & $50 \%$ & none & none & none & yes/no & $\begin{array}{l}\text { if yes - change } \\
\text { STRATEX } \\
\text { and/or } \\
\text { ressource } \\
\text { capacity } \\
\text { planning } \\
\end{array}$ \\
\hline Project 6 & $1.040 .000,00 €$ & $850.000,00 €$ & $\begin{array}{lll} & \bigcirc & 0 \\
0 & \bigcirc & 0 \\
0 & 0 & 0\end{array}$ & $\begin{array}{ll}0 & 0 \\
0 & 0 \\
0 & 0 \\
0 & 0\end{array}$ & $\begin{array}{ll}0 & 0 \\
0 & 0 \\
0 & 0\end{array}$ & on track & $60 \%$ & $40 \%$ & $50 \%$ & none & none & none & yes/no & $\begin{array}{l}\text { if yes - change } \\
\text { STRATEX } \\
\text { and/or } \\
\text { ressource } \\
\text { capacity } \\
\text { planning } \\
\end{array}$ \\
\hline Project 7 & $2.500 .000,00 €$ & $2.250 .000,00 €$ & $\begin{array}{lll}0 & \circ & 0 \\
0 & \bigcirc & 0 \\
0 & 0 & 0\end{array}$ & $\begin{array}{lll}0 & \bigcirc & 0 \\
0 & \bigcirc & 0 \\
0 & 0 & 0\end{array}$ & $\begin{array}{lll}0 & 0 & 0 \\
0 & 0 & 0 \\
0 & 0 & 0\end{array}$ & on track & $60 \%$ & $40 \%$ & $50 \%$ & none & none & none & yes/no & $\begin{array}{l}\text { if yes - change } \\
\text { STRATEX } \\
\text { and/or } \\
\text { ressource } \\
\text { capacity } \\
\text { planning }\end{array}$ \\
\hline
\end{tabular}

Table 25: SMB Tool Control 


\subsubsection{Step 5.2.: Build}

Within the Build step the project team (often with external suppliers) build the defined solution based on the requirements from the system proposal and within the solution approach presented in the system design. The project members deliver actual status regarding quality, costs and time in form of the progress status to the project manager. A standardized tool within the project tool helps to handle this communication and control topic in an efficient way.

\begin{tabular}{|c|c|c|c|c|c|c|c|c|c|c|c|}
\hline $\begin{array}{c}\text { Workpacka } \\
\text { ge }\end{array}$ & $\begin{array}{l}\text { Budget } \\
\text { planned } \\
\text { (in PD) }\end{array}$ & $\begin{array}{c}\text { Budget } \\
\text { spent } \\
\text { (in PD) }\end{array}$ & $\begin{array}{l}\text { Budget } \\
\text { spent } \\
\text { in } \%\end{array}$ & $\begin{array}{l}\text { Progress of } \\
\text { work in } \% \\
\end{array}$ & Included Tasks & Responsibly & Duration & Start & End & September & October \\
\hline \multirow[t]{13}{*}{ WP 4 Build } & 151,0 & 0,0 & $0 \%$ & $0 \%$ & Build Workpackages & & 184 Tage & Mit $17.04 .13 \mathrm{~N}$ & Mon 30.12.13 & & \\
\hline & & & & & Workpackage 1 & Person 1 & 0 Tage & Fre $30.08 .13 \mathrm{~F}$ & Fre 30.08 .13 & & \\
\hline & & & & & Workpackage 2 & Person 1 & 25 Tage & Mit 25.09.13 & Die 29.10.13 & & \\
\hline & & & & & Workpackage 3 & Person 2 & 10 Tage & Die $17.12 .13 \mathrm{~N}$ & Mon 30.12.13 & & \\
\hline & & & & & Workpackage 4 & Person 2 & 92 Tage & Don $16.05 .13 \mathrm{~F}$ & Fre 20.09.13 & & \\
\hline & & & & & Workpackage 5 & Person 2 & 14 Tage & Die $18.06 .13 \mathrm{~F}$ & Fre 05.07.13 & & \\
\hline & & & & & Workpackage 6 & Person 2 & 15 Tage & Mon $26.08 .13 \mathrm{~N}$ & Mon 16.09.13 & & \\
\hline & & & & & Workpackage 7 & Person 2 & 10 Tage & Mit 28.08.13 & Die 10.09 .13 & & \\
\hline & & & & & Workpackage 8 & Person 2 & 4 Tage & Mit $11.09 .13 \mathrm{~N}$ & Mon 16.09.13 & & \\
\hline & & & & & Workpackage 9 & Person 2 & 5 Tage & Mit 28.08.13 & Die 03.09.13 & & \\
\hline & & & & & Workpackage 10 & Person 2 & 49 Tage & Mon $16.09 .13 \mathrm{~F}$ & Fre 22.11.13] & & \\
\hline & & & & & Workpackage 11 & Person 2 & 49 Tage & Die $17.09 .13 \mathrm{~F}$ & Fre 22.11.13 & & \\
\hline & & & & & Workpackage 12 & Person 2 & 49 Tage & Die 17.09.13 F & Fre 22.11.13[ & & \\
\hline
\end{tabular}

Table 26: Project Build Tracker

\subsubsection{Step 5.3.: Test}

The test step has the main focus to test the results of the build phase for the implementation of the designed system. The tool of the test step is the generic test concept which describes all relevant settings regarding test organization, test processes and test tools.

The main sub-steps within the testing are presented in below chapters. 


\subsection{Definition of test-levels}

\begin{tabular}{|c|c|c|}
\hline Test Level & Objectives & Test Artefacts \\
\hline $\begin{array}{l}\text { Developer test } \\
\text { - } \quad \text { Component } \\
\text { Test } \\
\text { - } \quad \text { Component } \\
\text { Integration } \\
\text { Test }\end{array}$ & $\begin{array}{l}\text { Functional correctness of components. } \\
\text { Components interact as specified }\end{array}$ & $\begin{array}{l}\text { IT concept } \\
\text { (System proposal) } \\
\text { IT concept } \\
\text { Interface agreements }\end{array}$ \\
\hline $\begin{array}{ll}\text { System Test } \\
\\
\begin{array}{ll} & \text { System Test } \\
- & \text { System } \\
& \text { Integration } \\
& \text { Test }\end{array}\end{array}$ & $\begin{array}{l}\text { Correct implementation of business } \\
\text { requirements (CRs) } \\
\text { Functional and non-functional } \\
\text { requirements are realized correctly }\end{array}$ & $\begin{array}{l}\text { System Proposal } \\
\text { Business } \\
\text { Requirements } \\
\text { Use Cases }\end{array}$ \\
\hline Regression test & $\begin{array}{l}\text { Retest of critical test cases or failed test } \\
\text { cases which have yielded a defect and are } \\
\text { retested }\end{array}$ & $\begin{array}{l}\text { System } \\
\text { documentation } \\
\text { Business } \\
\text { Requirements }\end{array}$ \\
\hline Security test & Security of the application & Gateways, Connectivity \\
\hline $\begin{array}{l}\text { Infrastructure } \\
\text { Browser Test }\end{array}$ & $\begin{array}{l}\text { Usability and } \\
\text { compatibility of browsers (e.g. Firefox) }\end{array}$ & $\begin{array}{l}\text { Business } \\
\text { scenarios for all committed } \\
\text { browser versions }\end{array}$ \\
\hline $\begin{array}{l}\text { Load / Performance } \\
\text { Test }\end{array}$ & $\begin{array}{l}\text { Test for performance and stability under } \\
\text { load }\end{array}$ & $\begin{array}{l}\text { Reverence values from } \\
\text { production }\end{array}$ \\
\hline UAT & $\begin{array}{l}\text { System and department-comprehensive } \\
\text { correctness }\end{array}$ & $\begin{array}{l}\text { System Proposal } \\
\text { Business } \\
\text { Requirements } \\
\text { Use Cases }\end{array}$ \\
\hline
\end{tabular}

Table 27: Test Levels 
5.7.5.3.2 Definition of test phases

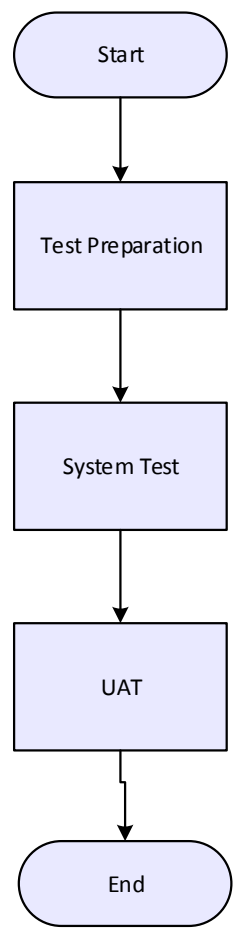

Figure 44: Test Phases 


\subsection{Definition of test roles and responsibilities}

\begin{tabular}{|c|c|}
\hline Role & Task \\
\hline $\begin{array}{l}\text { Defect } \\
\text { Manager / } \\
\text { Defect SPOC }\end{array}$ & $\begin{array}{l}\text { Manage, monitor and coordinate defect life-cycle. } \\
\text { Moderation of defect meetings } \\
\text { First instance in case of } \\
\text { escalations } \\
\text { Coordinate patching / negotiate patch times } \\
\text { Coordinate and align with change } \\
\text { management } \\
\text { Reporting } \\
\text { Ensure SLAs are met }\end{array}$ \\
\hline Tester & $\begin{array}{l}\text { Open and log defects } \\
\text { Assign severity } \\
\text { Provide fault description and error information for developers }\end{array}$ \\
\hline $\begin{array}{l}\text { Developer / } \\
\text { Analyst }\end{array}$ & $\begin{array}{l}\text { Acknowledge defects and } \\
\text { severities } \\
\text { Coordinate defect fixing } \\
\text { Ensure SLAs are met }\end{array}$ \\
\hline
\end{tabular}

Figure 45: Test Roles and Responsibilities 


\subsection{Definition of test reporting}
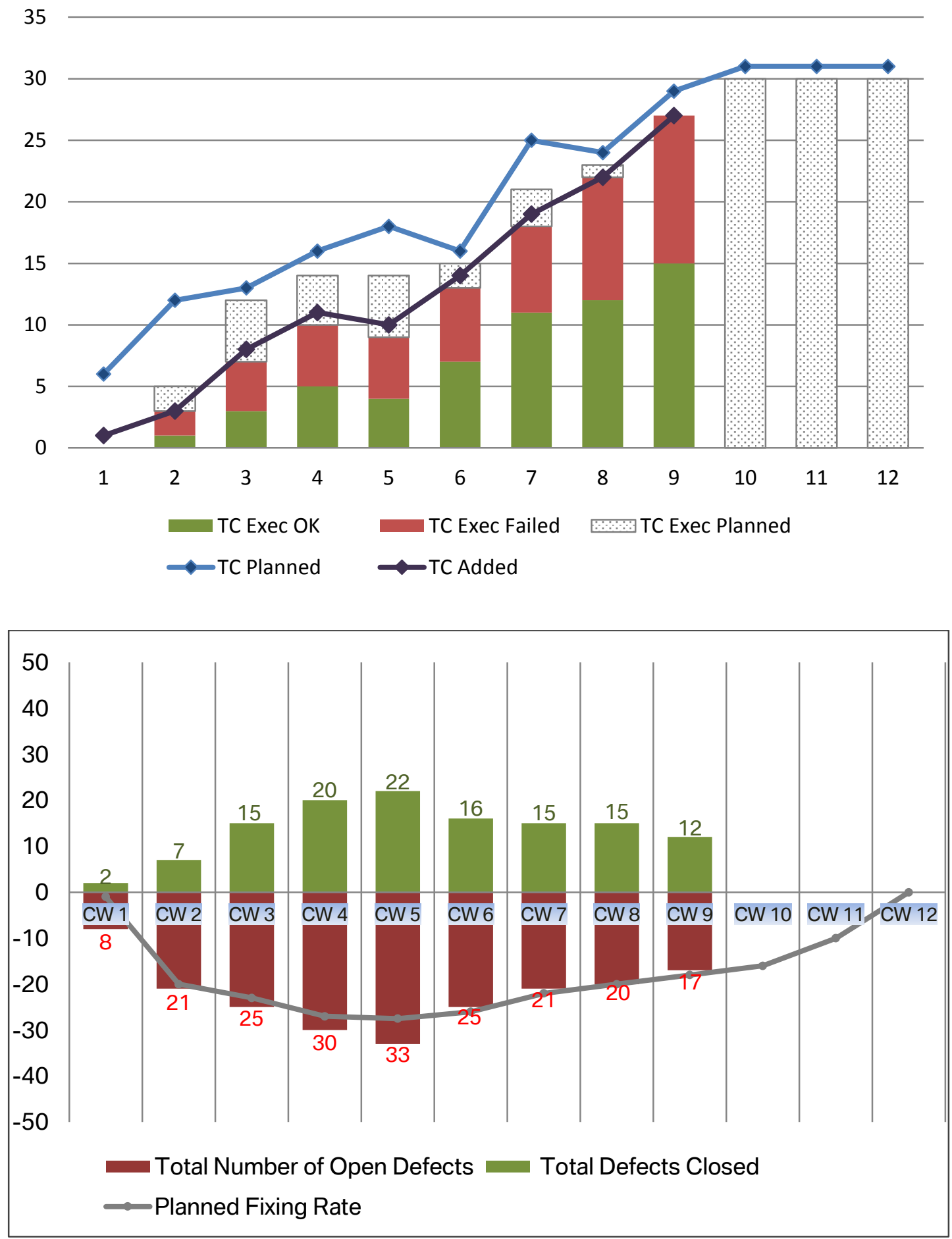

Figure 46: Examples of test reporting 


\subsubsection{Step 5.4.: Training and Documentation}

The training and documentation step is dedicated to present a best practice approach for train the organization with respect to the results from the project for an optimal usage of the build systems and to document the results.

The responsibility for this step is within the POrg, especially the project manager. The tool for this step is the generic training and documentation concept which defines the following topics.

- Definition of TARGET GROUPS and USERS

- Identification of users

○ User - Role matching

$\bigcirc \quad$ Introducing new users

- Prepare the TRAINING CONTENT

- Setup technical TRAINING ENVIRONMENT

- $\quad$ Define TRAINING TYPES

○ Management Information Events

- Training of Standard User

- Training of Expert Users

- Train the trainer

- Prepare DOCUMENTATION

○ Handouts

○ Quick Reference Guide

○ Multiple-Choice-Questionnaire

○ Storage 


\subsubsection{Step 5.5.: Rollout and transfer into operational business}

The last step of the ISOL-M is the rollout and transfer into operational business step. The rollout step is dedicated to a controlled go live of the system for the operational business. Main focus is to deliver the results of the project to the business. The transfer into line step ensures that operational units use the results from the project as planned and for that generate the planned contribution to the strategic goal. An optimal performance in the step "test" and "training" is the needed pre-condition for this step.

The last process of this step is the closure of the project in the SMB Council which leads to a discharge of the resources and a final closure of the costs lines in the STRATEX.

\subsection{Rollout}

The rollout step has six major process steps as shown in the below figure.

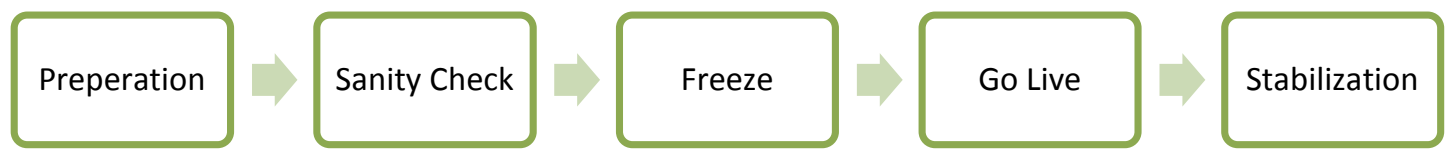

Figure 47: rollout process 
Preparation Step - The preparation step considers that the complete environment (organizational and technical) is prepared for the rollout. Sub-Steps like the definition of the freeze timeslot, setting the organizational responsibilities, definition of checklists and step-by-step processes, definition of possible roll-backscenarios are typical.

Sanity Check - The sanity check is walk through a list of all needed activities that need to be done with the go live.

Freeze - The freeze step is needed to get an optimal environment with as little as possible interactions and changes for the go-live.

Go-Live - The go-live is the step where the results of the project gets "switch online" into the actual business environment.

Stabilization - This phase is after the go live where for safety reasons a part of the project team is still on board to manage and control the first days of the new business.

\subsection{Transfer into line}

The transfer into line step is organized by the POrg together with the line managers. Basis for the actions in this step is the tool generic operational manual which is part of the project tool. The generic operational manual manages the following topics:

- Definition of the to-be business process, organization and tools

- Definition of the support processes and organization

- Definition of the system and functionality

- Monitoring and SLA Regulations

- Meetings and Lessons Learned Sessions 
- Escalation, Troubleshooting and Emergency Concepts

With respect to the ISOL-M model the lessons learned sessions and the monitoring are the topics to concentrate. Within the lessons learned sessions facts from running the business must be communicated to the SMBOrg for analysis and learning decisions regarding the next planned strategic actions. The monitoring tool must at least deliver the numbers that count for the project value to control and monitor the real values versus the planned values. 


\section{CONCLUSION}

Kaplan's theories, especially the execution premium provides an in the literature outstanding approach to link strategy and operations. This area is in the science literature barely developed and in the real business world a day-to-day problem area for international companies.

With getting a deeper look and understanding of Kaplan's model and challenging them with a real-life experiment some major GAP's could be discovered. The main topic, which is not provided by Kaplan, are the direct links between the processes, organizational responsibilities and tools for the complete cycle within the "strategy to operations"-framework.

\section{Phase 1: ISOL-M}
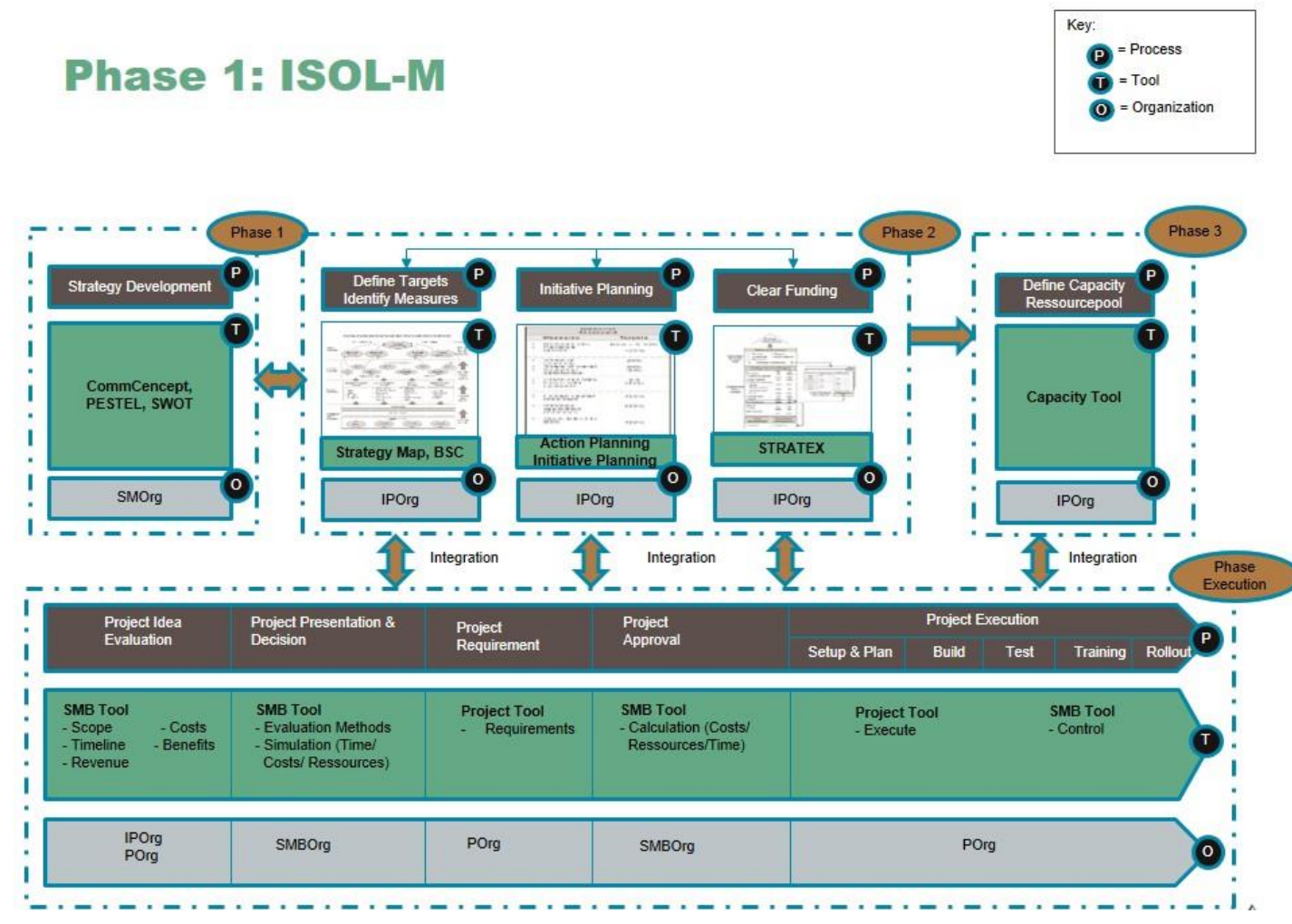

Figure 48: ISOL-M 
The development of the ISOL-M with its 4 major phases as shown in the above figure and the detailed description of processes, organizational responsibility and tool support can contribute to close the GAP's essentially. The combination of existing methods were chosen under the conditions of

- Value for strategy and operations

- Usability

- Potential for integrating in an overall model with respect of optimal interface opportunities.

The focus of the ISOL-M was not to invent some new specific method or tool within a specific area of strategy or operations management. The focus was on inventing an overall model with seamless interconnections and interfaces between given methods of strategy and operations management and providing the central theme of an integrated execution phase.

The experiment at the energy company had shown that there is the need of further developments of Kaplan's theories to close the GAPs and provide a practicable solution which helps companies to improve their strategy processes and transfer the organization into a strategy focused organization for getting on top of competitors. After the experiment and the development of the ISOL-M this new approach was tested within a follow-up consulting project at the energy company. The results of this followup project were tremendous.

Performing the ISOL-M helps the company to define suitable strategy approaches in an extremely changing market with following results: 
Product development: Optimization of time to market and customer satisfaction

Before implementing the ISOL-M the time to market for new products was around 20 to 24 month. Around $30 \%$ of developed products never made it into the market because customer's requirements changed within the development phase. One reason for that was that product development was not connected to strategic decisions. Every sales department developed their own products. Because of this, the supporting units like IT-Department were confronted with about 40 to 60 product ideas a year. Developing these product ideas without any strategy, without a suitable organization form like project oriented matrix organization structures and without defined and standardized project processes seem obviously impossible.

After the implementation of the ISOL-M with its structured processes, new setup organizational form and the interconnection of every action with the strategy the time to market for a product decreased to 6 month in average. The product ideas have been sorted out by the project decision processes and the approved projects decrease to around 15 per year, and about 6-8 in the area of product development. Since the implementation of the ISOL-M every product was purchased by the customer.

\section{Change of leadership with matrix organization structure}

As already mentioned in the GAP analysis the company was at the beginning not ready for the changes coming up with the implementation of the ISOL-M cause of two reasons. First: the organizational setting of the company was strictly functional oriented. All business departments were strictly functional and the management from top to middle management level acts within this functional restrictions. Second: the company has barely developed knowledge, competency and experience in project 
management, cause the focus within the functional organization was operational and department oriented.

With the implementation of the ISOL-M the organizational structure of the company has changed and transferred to a matrix-oriented and therefore project oriented organizational structure. After investing in programs of educating project management competencies and transferring the organization to a matrix structure the result was a much more flexible organization, which now can handle very quickly and effectively the day-by-day challenges in a competition driven market. So the implementation of the ISOL-M with its organizational requirements made the company better prepared for the future.

Another improvement was the way how leadership changes with the implementation of the ISOL-M. Before the project the top level management had to deal with a limited circle of next-level managers, concrete the 4 to 5 line or department managers of the functional oriented organization. After the implementation they had to deal additional with the matrix responsible managers, especially the initiative and program managers. This changes the way of leadership and daily management behavior from the ground. There was the need for a special change management program for the top level management to rise their skills to perform within this new organizational structure. After breaking the mindset barriers in this area the top level management was fully able to act effectively and totally strategy-oriented on a professional level. For that reason the implementation of the ISOL-M brought another improvement to the company: the rise of a modern and flexible art of leadership needed for getting on the top of competition in a restricted market environment. 
Align organization by linking strategy goals to incentive programs

Another improvement of the implementation of the ISOL-M was the successful alignment of the organization to strategy goals. Within the functional organization structure the goals for every employee were defined by department goals broke down to personal goals for the employee. The adding of strategic goals to the personal goals and link them with the incentive program of the company provided a quick and effective way of aligning the organization with the strategic goals. With this change the mindset of the employees changes immediately. They cared about the realization of the strategy the same way the cared before about the realization of the department goals. Therefore a totally new mindset directly connected to the strategy came up.

\section{Proactive management with new management system tools}

Before the project the company acts very reactively on external and internal changes and therefore they often were in the position of being late to the trends and needed changes for a successful business. With the implementation of the ISOL-M and its performance tools, especially the SMBTool they get into a position of being able to proactively act on the market. With this management system tool they were able to outperform their competitors by speed and quality which results in better revenue numbers and lower costs.

The implementation of the ISOL-M was the basis for the company to outperform their competitors in the last two years with innovative products, customer satisfaction, employees which are highly motivated and act directly to strategic goals, a top level management which is able to steer the company in the framework of set vision, mission and strategy into a successful future and last but not least excellence revenues and 
growth. The company rises with respect to revenue and market share from number 7 to number 4 of all energy companies in Germany.

The ISOL-M has after this first project with the energy company been performed several times in the automotive and telecommunication industry. The actual experience implementing and performing the ISOL-M proofs that this generic model for industrial oriented companies brings enormous added value. 


\section{REFERENCES}

Anderson, S., \& Kaplan, R. (2007). Time-Driven Activity-based Costing. Harvard Business School Press.

Anonymous, a. t. (544 BC). The Art of War.

Baldwin, C., \& Clark, K. (1994). Capital-Budgeting System and Capabilities Investments in the U.S. Business History Review.

Collis, D. (2008). Can You Say What Your Strategy is? Harvard Business Review.

Collis, D., \& Montgomery, C. (1998). Creating Corporate Advantage. Harvard Business Review.

Eckerson, W. (2006). Perfomance Dashboards: Measuring, Monitoring, and Managing Your Business. Hoboken.

http://www.businessdictionary.com/definition/process.html. (2013).

Johnson, L. (2007). Common Sense in Strategy Communication. Balanced Scorecard Report.

Jorgenson, B. (2001). Borealis. Harvard Business School Press.

Kaplan, R. (2005). Limits to Benchmarking - Balanced Scorecard Report. HBS Publishing Newsletter.

Kaplan, R., \& Norton, D. (1996). The Balanced Scorecard. Business Harvard School Press.

Kaplan, R., \& Norton, D. (2000). The Strategy-Focused Organization. Harvard Business School Press. 
Kaplan, R., \& Norton, D. (2001). The strategy-focused Organization. Harvard Business School Press.

Kaplan, R., \& Norton, D. (2005). The Office of Strategy Management. Harvard Business Review.

Kaplan, R., \& Norton, D. (2008). The Execution Premium. Harvard Business School Press.

Kotter, J. (1996). Leading Change. Harvard Business School Press.

Lee, S., \& Ko, A. (2000). Building balanced scorecard with SWOT analysis, and implementing "Sun Tzu's the Art of Business Management Strategies" on QFD methodology". Managerial Auditing Journal .

Lynch. (2009). strategic management. England: Pearson Education Limited.

Mintzberg, H., \& J. Waters. (1985). Of Strategies, Deliberate and Emergent. Strategic Management Journal, 257-272.

Nixon\&Helms. (2010). Exploring SWOT Analysis - a review of academic research from the last decade. Journal of Strategy and Management.

Panagiotou, G. (2003). Bringing SWOT into focus. Business Strategy Review.

Pellegrinelli, S. (1997). Programme management: organising project-based change. Int J Project Manage.

Pickton, D., \& Wright, S. (1998). Whats SWOT in strategic analysis? Strategic Change. Porter, M. (1996). What is Strategy? Harvard Business Review.

Project Management Institute. (2013). A Guide to the Project Management Body of Knowledge. Newtown Square: Project Management Institute.

R., L. (2009). strategic management. England: Person Education Limited.

Strategic Direction. (2008). Director input to corporate strategy. Emerald Group Publishing Limited. 
Tuna, C. (2008, 11 20). Executives Shift to Survival. Wall Street Journal, p. Internet. Yüksel, I. (21.11.2012). Developing a Multi-Criteria Decision Making Model for PESTEL. International Journal of Business and Management. 


\section{APPENDIX}

\section{Abbreviations}

\begin{tabular}{|c|c|}
\hline $\mathrm{ABC}$ & Activity-based Costing \\
\hline BSC & Balanced Score Card \\
\hline CAPEX & Capital Expenses \\
\hline CEO & Chief Executive Officer \\
\hline CSF & Critical Success Factors \\
\hline $\mathrm{CMO}$ & Chief of Marketing and Sales \\
\hline HR & Human Resources \\
\hline ERP & Enterprise Resource Planning \\
\hline EU & European Union \\
\hline GPM & German Institute for Project Management \\
\hline IPOrg & Initiative and Program Organization \\
\hline ISOL-M & Integrated-Strategy-to-Operations-Linking-Model \\
\hline ITPM & IT Process Quality Management \\
\hline MRP & Material Resource Planning \\
\hline OAS & Objective Advantage Scope \\
\hline OPEX & Operating Expenses \\
\hline OSM & Office of Strategy Management \\
\hline $\mathrm{P} \& \mathrm{~L}$ & Profit-and-Loss Statement \\
\hline PDCA & Plan-Do-Check-Act \\
\hline
\end{tabular}


PESTEL

POrg

PTO

$R \& D$

RASI

ROI

SMB

SMBOrg

SMO

SMOrg

STRATEX

SWOT

TDABC

TQM
Political, economical, social, technological, environmental, legal Project Organization

Processes, Tools, Organization

Research and Development

Responsible, accountable, consult, inform

Return On Invest

Strategy Management Board

Strategy Management Board Organization

Strategy Management Office

Strategic Management Organization

Strategic expenses

Strengths, Weaknesses, Opportunities, Threats

Time-Driven Activity-Based Costing

Total Quality Management 


\section{CURRICULUM VITA}

NAME:

ADDRESS:

DOB:

EDUCATION

\& TRAINING:
Alexander Bogner

Adalbertstrasse 108

80469 Munich

Germany

Munich, $2^{\text {nd }}$ of November 1975

Diplom Kaufmann,

University of applied science Hamburg

$2001-2005$

Master of Science Industrial Engineering

University of Louisville

$2009-2010$

PROFESSIONAL SOCIETIES:

Senior Partner

Infologis AG

Strategy execution consulting 